\title{
Historical, Architectural and Archaeological Investigations at the Steiner-Schob Complex Victoria County, Texas
}

Anne A. Fox

Katherine Livingston

Follow this and additional works at: https://scholarworks.sfasu.edu/ita

Part of the American Material Culture Commons, Archaeological Anthropology Commons, Environmental Studies Commons, Other American Studies Commons, Other Arts and Humanities Commons, Other History of Art, Architecture, and Archaeology Commons, and the United States History Commons

Tell us how this article helped you.

This Article is brought to you for free and open access by the Center for Regional Heritage Research at SFA ScholarWorks. It has been accepted for inclusion in Index of Texas Archaeology: Open Access Gray Literature from the Lone Star State by an authorized editor of SFA ScholarWorks. For more information, please contact cdsscholarworks@sfasu.edu. 
Historical, Architectural and Archaeological Investigations at the Steiner-Schob Complex Victoria County, Texas

\section{Creative Commons License}

\section{(c) (1) (8)}

This work is licensed under a Creative Commons Attribution-NonCommercial 4.0 International License 


\title{
HISTORICAL, ARCHITECTURAL AND ARCHAEOLOGICAL \\ INVESTIGATIONS AT THE STEINER-SCHOB COMPLEX \\ VICTORIA COUNTY, TEXAS
}

Anne A. Fox and Katherine Livingston

With an Appendix by

Thomas W. Medl in

\begin{abstract}
Center for Archaeological Research
The University of Texas at San Antonio

Archeological Survey Report, No. 52
\end{abstract}

1979

Prepared for the Guadalupe-Blanco River Authority 


\section{ABSTRACT}

In May 1977, the Center for Archaeological Research, The University of Texas at San Antonio, and the firm of Eugene George, AIA Architect, carried out an intensive investigation and recording of a German farmstead in Victoria County, Texas. A detailed history of the family and the site and a complete architectural recording and analys is are included. Archaeological investigations of standing structures and sites of former structures are described. The results of the investigations are discussed in relation to archaeological investigations at other rural sites. Appendices on phosphate testing and detailed architectural drawings of the Schob house are included. 


\section{TABLE OF CONTENTS}

Page

List of figures. .................. . . $i$. .

List of Tables..................... ... i ... . . .

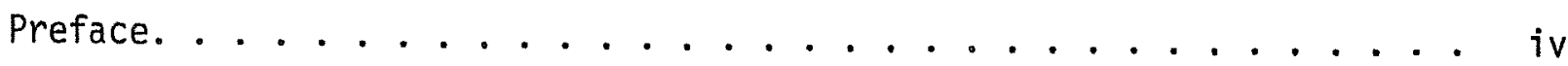

Acknowledgments. .................... $v$

I. General Introduction .................. 1

II. The Setting. .................. 2

III. History and Architecture . . . . . . . . . . 5

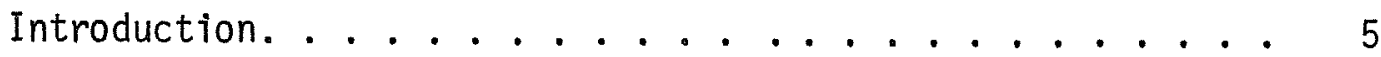

Historical Narrative. . . . . . . . . . . . . 5

Architectural Description ............. 11

IV. Archaeological Investigations. ............. 26

Introduction. .................... 26

Previous Archaeological Work. . . . . . . . . . . 26

Methodology ................... . . 26

The Schob Site................. . 27

The Steiner Site. .............. . . 37

v. Discussion ................ . 70

Comparison of Steiner and Schob Sites ......... 70

Census Reports. . . . . . . . . . . . . . 74

Comparison with other Sites ........... 75

VI. Summary and Conclusions. . . . . . . . . . . . . . 77

References Cited . . . . . . . . . . . . . . 80

Appendix I: Soil Analysis (Thomas W. Medlin). . . . . . . . 87

Appendix II: Architectural Drawings of Friedrich Schob House. . . . 92 


\section{LIST OF FIGURES}

Figure

Page

1. Location Plan, Steiner-Schob Property. . . . . . . . . . . 3

2. Map of Steiner's Town Area in 1864. . . . . . . . . . . . 6

3. Family Photographs ... . . . . . . . . . . . . . 8

4. Outbuildings . . . . . . . . . . . . . . 10

5. Steiner House Photographs. . . . . . . . . . . . . . 12

6. Steiner House Framing. . . . . . . . . . . . . . . 13

7. Steiner House Details. . . . . . . . . . . . . 15

8. Schob House, Southeast Elevation . . . . . . . . . . . 16

9. Architectural Details.................. 18

10. Schob House, Southwest Elevation .............. 19

11. Interior Stairs, Second Floor. . . . . . . . . . . . 20

12. Hardware . . . . . . . . . . . . . . . . . . . 21

13. Kitchen Details. . . . . . . . . . . . . . 23

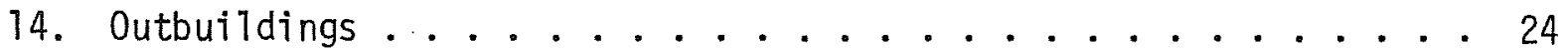

15. Schob-Steiner Complex Location Map . . . . . . . . . . . 28

16. Friedrich Schob House, Plan of Farm Structures . . . . . . . . 29

17. Excavations at the Schob House, Photographs. . . . . . . . 30

18. Excavations at the Schob Farm, Drawings. . . . . . . . . . 31

19. Artifacts from Schob Kitchen . . . . . . . . . . . . . 34

20. Metal Artifacts from Schob Kitchen . . . . . . . . . . . 35

21. Log Shed at Schob Farm . . . . . . . . . . . . . . 38

22. Steiner Site (4T VT 62), Site Plan.............. 39

23. Excavations at Steiner House, Structure 1 . . . . . . . . . 41

24. Steiner Site (41 VT 62), Excavation Profiles . . . . . . . . 42

25. Steiner Site (41 VT 62), Plan of Structure 1......... . 43 
List of Figures (continued)

Figure Page

26. Excavations at Steiner House, Structure 1......... 45

27. Excavations at Steiner Site, Structure 2 ........ 46

28. Steiner Site (41 VT 62), Plan of Structure 2 ...... 47

29. Cast Iron 0bjects from Steiner Site . . . . . . . . . 49

30. Views of Steiner Site Features. ............ 50

31. Glass and Ceramics from Steiner Site, Structure 2 . . . . . 54

32. Artifacts from Steiner Site, Structure 3 ........ 55

33. Ceramics from Steiner Site, Structure 1......... 56

34. Glass from Steiner Site, Structure 1......... 58

35. Bottles from Steiner Site, Structure 1 . . . . . . . 59

36. Metal Artifacts from Steiner Site, Structure 2 . . . . . 63

37. Metal Artifacts from Steiner Site, Structure 1 . . . . . 64

38. Hardware from Steiner Site, Structure 1......... 66

39. Ceramic Vessels Still in Steiner Family .......... . 71

40. Raisin Band, ca. 1905 ............. 78

41. Steiner Site (41 VT 62), Phosphate Test........ 89

\section{LIST OF TABLES}

Table

Page

1. Schob Site (41 VT 61), Artifact Provenience Chart . . . . . 33

2. Steiner Site (41 VT 62), Artifact Provenience Chart ..... 53

3. U.S. Census Data. . . . . . . . . . 72 


\section{PREFACE}

The following report has been a cooperative effort of Anne Fox of the Center for Archaeological Research and Katherine Livingston of the office of Eugene George, AIA Architect. Sections I, II, IV and V were written by Fox; Section III by Livingston. Appendix I on phosphate testing was written by Thomas Medlin, who carried out the testing on the site. Architectural drawings in Section III and Appendix II were done by Livingston. Daniel E. Fox did the maps (except for Figures 1 and 2) and the archaeological drawings, as well as the sketch of the Steiner House used on the cover of the report. 


\section{ACKNOWLEDGMENTS}

As in any project of this type, close cooperation and coordination were necessary between the various aspects of the work, with each phase contributing necessary ingredients to expedite the work of the others. This cooperation was carried out with a minimum of difficulty due to the enthusiasm and interest of everyone concerned, including the archaeologists, the architect and the Steiner and Schob descendants who generously shared their information and family stories.

We are particulariy grateful to the following family members who helped with the project:

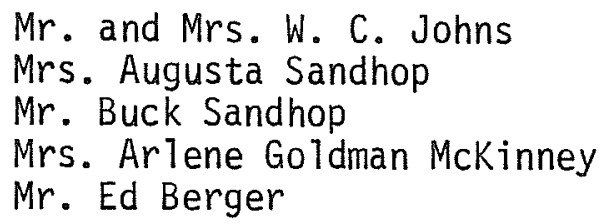

David Welsch and the staff of the Guadalupe-Blanco River Authority office in Victoria, Carol Dinkins of the law firm of Vinson and Elkins, and Alton Briggs of the Texas Historical Commission were helpful in expediting the project.

Help with historical research was generously provided by:

Martha Freeman Doty of the Texas Archeological Survey Karen Hand of the Victoria Public Library Katherine McDowe11 of the Daughters of the Republic of Texas Library $\mathrm{Dr}$. Robert Shook of Victoria Community College

The following people were particularly helpful in special ways:

Dr. Georgeanna Greer identified the Texas-made pottery.

William Todt identified the automobile parts.

Shirley Van der Veer photographed the ceramic vessels owned by the family. Billy Davidson of the Center staff did the faunal identification.

Dr. Woodruff D. Smith, Associate Professor of History at The University.. of Texas at San Antonio, provided a translation of the chapter from Schütze's Jahrbuch.

The archaeological crew consisted of:

Stephen Black

David Brown

Daniel Fox

Steven James
Paul Lukowski

Thomas Medlin

Billy Pat Newman

Jack Eaton, Assistant Director of the Center, aided the project in various ways. Dr. Thomas R. Hester, Director of the Center, served as Principal Investigator. 


\section{GENERAL INTRODUCTION}

In 1974 the Guadalupe-Blanco River Authority contracted with the Center for Archaeological Research of The University of Texas at San Antonio to conduct an archaeological assessment of lands to be affected by a dam, reservoir and power plant which were about to be constructed as a joint undertaking of the River Authority and the Central Power and Light Company, on Coleto Creek west of Victoria. During the first phase of the survey in 1975, 49 prehistoric archaeological sites were recorded on land to which the archaeological crew was allowed access (Fox and Hester 1976).

As the second phase of the archaeological project, an archaeological crew from the Center spent the month of March 1977 testing recommended sites on the reservoir. At that time, the crew also was requested by the Guadalupe-Blanco River Authority to examine and assess the historic importance of the SteinerSchob complex, a 19th century German farm at the southeast end of the reservoir. The complex consisted of the mid-19th century Steiner farmstead, which was assigned the state registration number 41 VT 62, and the 1ate 19th century Schob farmstead, which was designated 41 VT 61. Since planned dam construction was expected to call for removal or demolition of all the structures on the two sites, it was recommended that a project be undertaken to recover as much information as possible on their history and architecture.

In response to this recommendation, in May 1977 an archaeological crew under the direction of Anne Fox of the Center and Katherine Livingston of the Austin office of Eugene George, AIA Architect, cooperated in an effort to recreate the history of the Steiner and Schob sites through archaeological testing, historical research, oral history and architectural recording.

Katherine Livingston conducted historical research in the archives of the town of Victoria and reviewed numerous publications on the Germans in Texas. She also spent many hours interviewing family members to compile as much information as possible on the location, construction and use of the various buildings on the two farmsteads. In addition, she made measured drawings of the Schob house and the barn, which once was the Steiner house, and took photographs to document the architecture of the Schob site.

The archaeological crew conducted test excavations at the proposed location of the first kitchen at the Schob house and found and identified the other earliest structures there. They also located and identified three structures at the Steiner site and were able to tentatively reconstruct the Steiner farmhouse and related outbuildings on paper. 


\section{THE SETTING}

The Steiner-Schob complex is located on the east bank of Coleto Creek near its confluence with Perdido Creek, approximately 10 miles from Victoria (Fig. 1). The area is a gently rolling, coastal prairie at an average altitude of 100 feet above sea level. The climate is humid subtropical, with hot summers and cool winters influenced by polar air masses which create large temperature fluctuations. There is a rainy season in the late spring to early summer and another in the fall.

0ther than occasional severe thunderstorms which cause flooding on local creeks and rivers, the major destructive force to affect the area has been the hurricane. High winds and extreme flooding caused by hurricanes periodically wreak havoc in the Texas coastal plain and have been a factor in the building and rebuilding sequence at the Steiner-Schob complex.

Soils in the area are primarily of the Telferner series, composed of brownishgray sandy loam of various depths over red-brown or yellow-brown clay (Fox and Hester 1976:3-4).

Coleto Creek lies in a zone of transition between the thorny brush and cacti of the Tamaulipan Biotic Province to the southwest and deciduous forests of the Texan Biotic Province to the northeast. Native vegetation on the site consists primarily of live oak, huisache, hackberry, anaqua and mesquite, alternating with open grassy areas. The wild mustang grape festoons the thickets, much as it did when the first settlers arrived.

No plants or trees were found which appear to have been planted purposefully on the Steiner site. The spacing and arrangement of the large anaqua trees which shade the Schob house and yard suggest that they may have been planted there. Anaquas are known to have been cultivated for shade for over 100 years in the Victoria vicinity (Victoria Sesquicentennial 1974:29).

Mammals present include opossum, various types of bats, armadillo, cottontail rabbit, fox squirrel, various mice, whitetail deer and the ever-present Plains pocket gopher. There are also numerous types of reptiles and fish in and near the creeks, and birds of both local and migrating species in great quantity and variety.

Man has been present in the Coleto Creek area for at least 9000 years. Archaeological sites in the area contain evidence of man's presence from the PaleoIndian period, roughly 7000 to 5000 B.C., through the Late Prehistoric period, A.D. 1000 to the first European contact (Fox and Hester 1976). The first Europeans who entered the area in the 17th century reported that there were groups of Indians living on the bays and rivers in the Victoria area. These appear to have been the Aranama, a Coahuilteco-speaking band who Tived primarily on the Guadalupe River near present-day Mission Valley, and the Karankawa, who ranged the coastal bays and islands, occasionally moving farther inland for brief periods. Evidently a group of Tonkawa, a central Texas group, migrated into the area in the 18th century (Linn 1883:334).

The first European influence in the immediate area occurred when the Spanish Mission Espiritu Santo de Zuniga and Presidio Nuestra Señora de Loreto were 


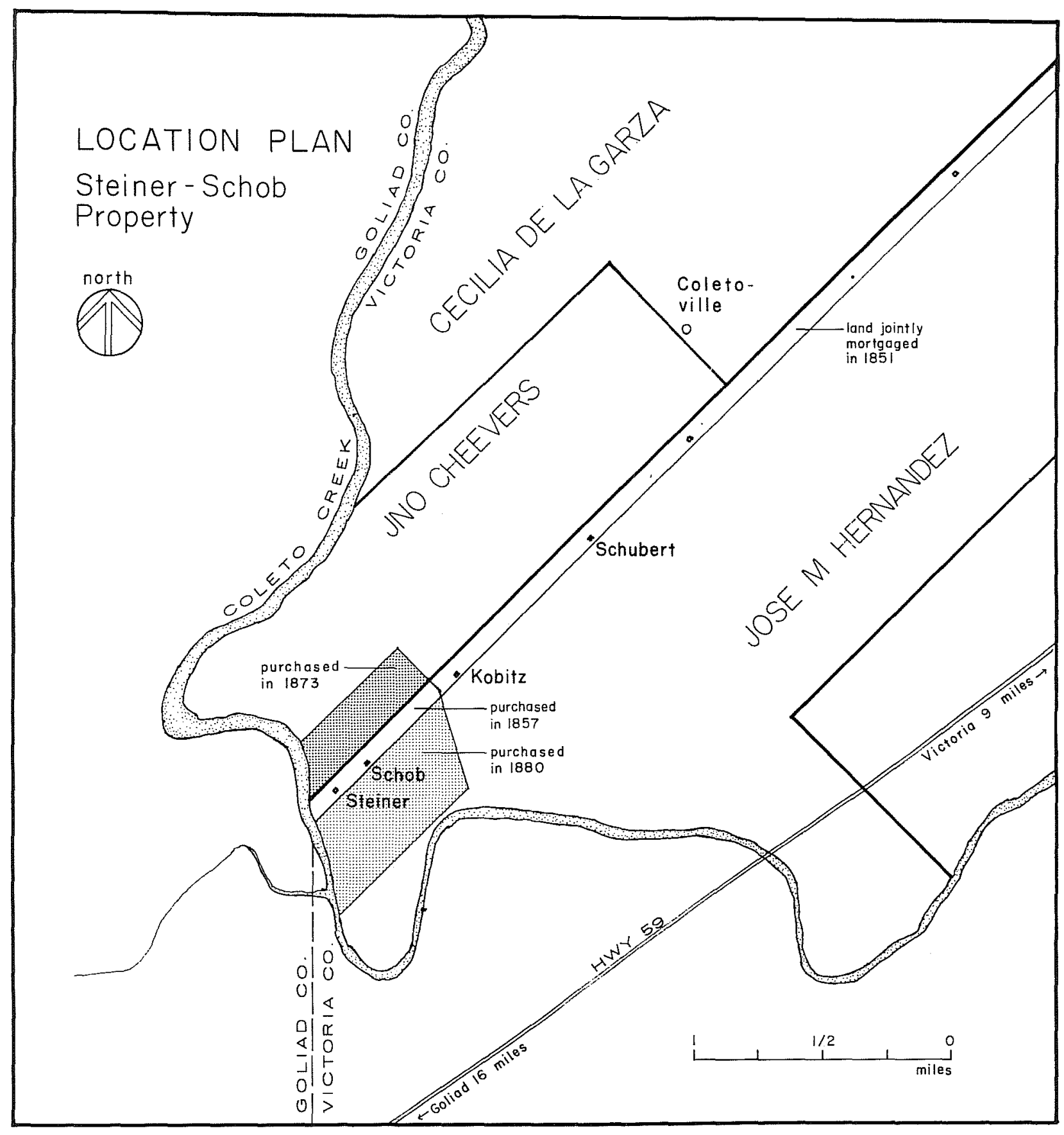

Figure 1. Location Plan, Steiner-Schob Property. 
moved to the Guadalupe River north of the present site of Victoria in 1726 (Castañeda 1936:168-169). However, the Spanish influence was comparatively brief, as the mission and fort were moved to the present site of Goliad in 1749 (ibid:79-113).

It was not until the arrival of Empressario Don Martin de Leon in 1824 that Europeans again entered the Coleto Creek area. In that year the town of Victoria was founded and 41 families settled on the surrounding lands (Rose 1883:10). In 1835 Jose Maria Hernandez and John Cheevers received grants of Tand in the area where the Steiner-Schob complex was later built (Walsh 1879). These were the first land grants with in the reservoir area. There are local stories of earlier settlers on the Guadalupe River, but no physical evidence of their dwellings has yet been found within the Coleto Creek drainage.

The Texas Revolution in 1835-36 did not directly involve the Coleto Creek area, al though the battle which resulted in the capture of Fannin, sometimes called the Battle of Coleto Creek, took place six or seven miles southwest of the Coleto Creek crossing of the Victoria Road. The principal effect of the revolution upon the general area was the flight of the Mexican population to Mexico and their subsequent replacement by Anglo-Americans who moved in and took over their land (0'Connor 1966:243). This could account for the change in nationality of the owners of the property which was to become the Steiner farm in 1851.

Since Victoria was a major stop on the cart road and immigrant route from Indianola to San Antonio and the new German settlements at New Braunfels and beyond, a number of immigrants had settled in the town rather than go farther inland. By 1860 Victoria had a notably cosmopolitan population:

The foreign born were predominantly German, as there were 551 inhabitants of German origin, and their influence on the life and culture of the little town had been extremely beneficial. They supplied many of the artisans of the building trades, and also contributed a great deal to the educational facilities, the social graces, appreciation of music and the like. Next in ethnic background were the Negroes, with about 500 . Then came the French (mainly Alsace-Lorraine) with 93 inhabitants. Then there were Mexico, with 78; Poland, 30; Ireland, 26; England, 18; Switzerland, 15; Denmark, 4; Canada, 4; Sweden, 2; Be1gium, 2; and Cuba, 1 (Victoria Sesquicentennial 1974:43).

This, then, was the flavor of the town to which Carl Steiner brought his wife and daughters to make a home in the "New World." 


\section{.III. HISTORY AND ARCHITECTURE}

\section{INTRODUCTION}

Data for this report on the Steiner-Schob complex were gathered during March, April and May of 1977. We felt that, in addition to measuring and recording the existing structures, it was important to document the people who built and used the structures, and the context in which they were built. A variety of primary and secondary sources were investigated.

Interviews were conducted with descendants to learn about the use and location of the structures on the sites, as well as to gather data on family members. Descendants had in their possession newspaper clippings, old photographs and original tax receipts pertaining to the sites. Deeds, probate records and naturalization papers at Victoria County Courthouse were utilized in addition to a deed abstract of the property. Census records and county tax records at the Texas State Library were searched. Published sources about Germans in 19th century Texas, newspaper articles and travelers' accounts of the period were reviewed to gain insight into the culture and technology at the time, as well as specific information about the settlements on Coleto creek. Various sources for maps of the area were searched--the Barker History Center at The University of Texas (UT) at Austin, the Texas State Library, the General Land Office, the Texas Highway Department and Victoria Community College. Victoria Community College has a copy of an 1864 Confederate map of the area that was of particular interest (Fig. 2).

The following collections of photographs and drawings of early Texas buildings were surveyed for information relating to architectural development in the area: the photographic collections at the Texas State Library, the Archives at the Barker History Center, the Texas Architectural Survey on file at UTAustin and the Texas Historical Commission surveys. Unfortunately, an architectural survey has not been conducted in this immediate area. Thus, there has been little documentation, for comparative purposes, on the early rural buildings in the Victoria area, except for a few we11-known structures.

We did discover that the Schob house had been measured and drawn in 1960 by students at The University of Texas at Austin. These student drawings, on file in the Architectural Archives at the School of Architecture, were not complete but were useful in our research. The original drawings used in this report will be filed with the Historic American Building Survey in Washington, D.C. Full scale blueline prints, field notes and photographs will be on file at the office of Eugene George.

\section{HISTORICAL NARRATIVE}

Many of the German immigrants in Texas during the 19th century arrived through the port of Indianola or Carlshafen. Though their original destination was New Braunfels or Fredericksburg, many found the lands along the inland routes to be attractive and settled there without going farther. The lower Guadalupe River and its tributaries appeared very attractive to the Germans, and many settled in Dewitt, Victoria and Goliad Counties (Jordan 1966:55). Bracht in Texas in 18481 isted the best-adapted points in western Texas for German settlements. 


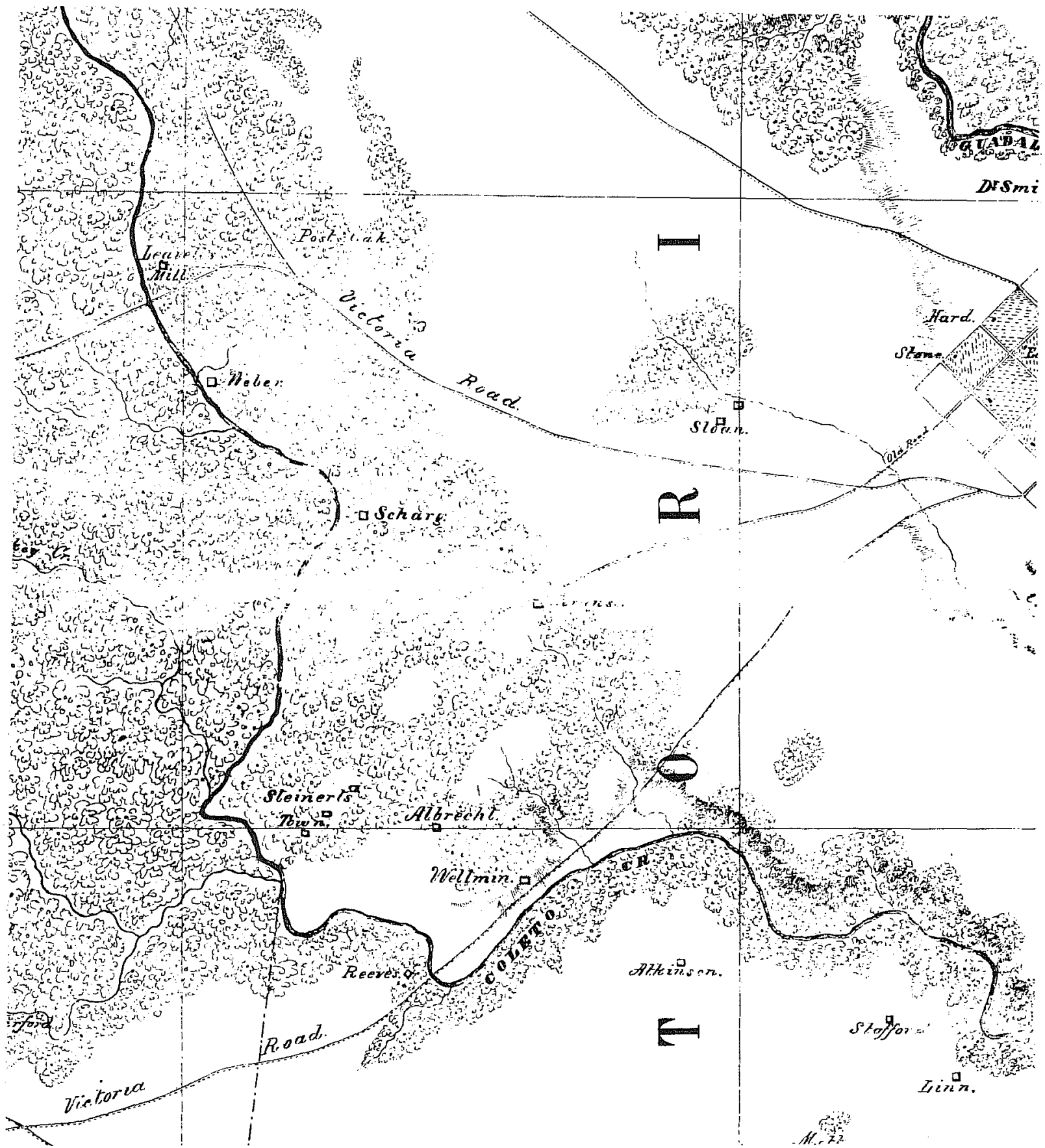

Figure 2. Map of Steiner's Town Area in 1864. Taken from topographical map of the country between the San Antonio and Colorado Rivers in the state of Texas. Confederate map, 1864 (Brown 1864). 
Among the areas he included was "the vicinity of Goliad, especially along the Coleto, where a considerable number of German families have already settled" (Schmidt 1931:142-143).

Coletoville, located on Coleto Creek nine miles west of Victoria, developed in the early 1850s. At one point the community consisted of a store, post office, church, school and a shooting hall (Eichholz 1883:84). In 1854 the Coleto Gesangverein, or singing society, was established.

Coletoville was one of the few early German settlements in Texas that did not prosper. By 1884 the post office and the store no longer existed (Biesele $1930: 58,65)$. Except for the schoolhouse and an 1873 church building, a 11 the architectural artifacts of this settlement have disappeared. However, the church has remained a very active part of the surrounding rural community, as exemplified by a large, well-maintained cemetery and a new church building under construction.

Coletoville was first called Steiner's Settlement or Steiner's Town after its acknowledged founder, Carl Steiner, who came to Texas ca. 1849-1850. Family tradition relates that he came over to secure land and then sent for his family (Fig. 3). In 1851 Steiner and five other Germans--Gottlieb Krause, Albert Schubert, Anton Bohn (or Bohen), John Polka and August Kolle--jointly mortgaged approximately 267 acres in Victoria County from a man named Peter Scheiner. The property was a narrow strip of land about 417 feet wide extending from Coleto Creek on the west to Dry Creek on the east. Terms of the agreement were that Charles Steiner et al. would pay $\$ 80$ cash and carry two notes, one for $\$ 150$ without interest due in one year and the second for $\$ 150$ at $8 \%$ interest due the following year (Deed Records 15:30-31). In 1856 a deed was granted to Carl Steiner et al. for the 267 acres (Deed Records 6:519). The next year the group divided the property into smaller tracts for sale with Steiner, Krause, Schubert, Bohen and Joseph Kobit purchasing the smaller tracts individually (Deed Records 6:544-551). Steiner's share of the land was 40 acres located on the extreme western protion of the tract and was the only tract to have frontage on Coleto Creek (Deed Records 6:547; see Figs. 1,2).

Steiner's wife, Victoria, and their three daughters followed him to Texas sometime during the 1850s. Exactly when they arrived is not known. Based on the family tradition and the possessions the family brought with them from Germany, we assume they were well educated and of an upper social class. Some of their possessions which have remained in the family include a number of books (several by Schiller written in high German), a white porcelain coffeepot with Victoria Steiner's name on it, a delicate china cup with handle, white cups and saucers with a leaf motif, and a holy water vessel. Pieces of furniture believed to have been brought by the Steiners include two wooden chests, a dresser, a table, a roller organ and a rocking chair.

The United States Census of 1860 provides clues to the overall picture of the homestead at that time. Victoria Augusta and Carl Steiner lived with two of their three daughters: Minna, 19 years old, and Augusta, 13 years old. Their oldest daughter had already married A. Goldman and lived in Victoria.

The Steiners' personal property was valued at $\$ 350$; they owned no siaves. Sixteen of their 40 acres were improved; total value of the real estate was 


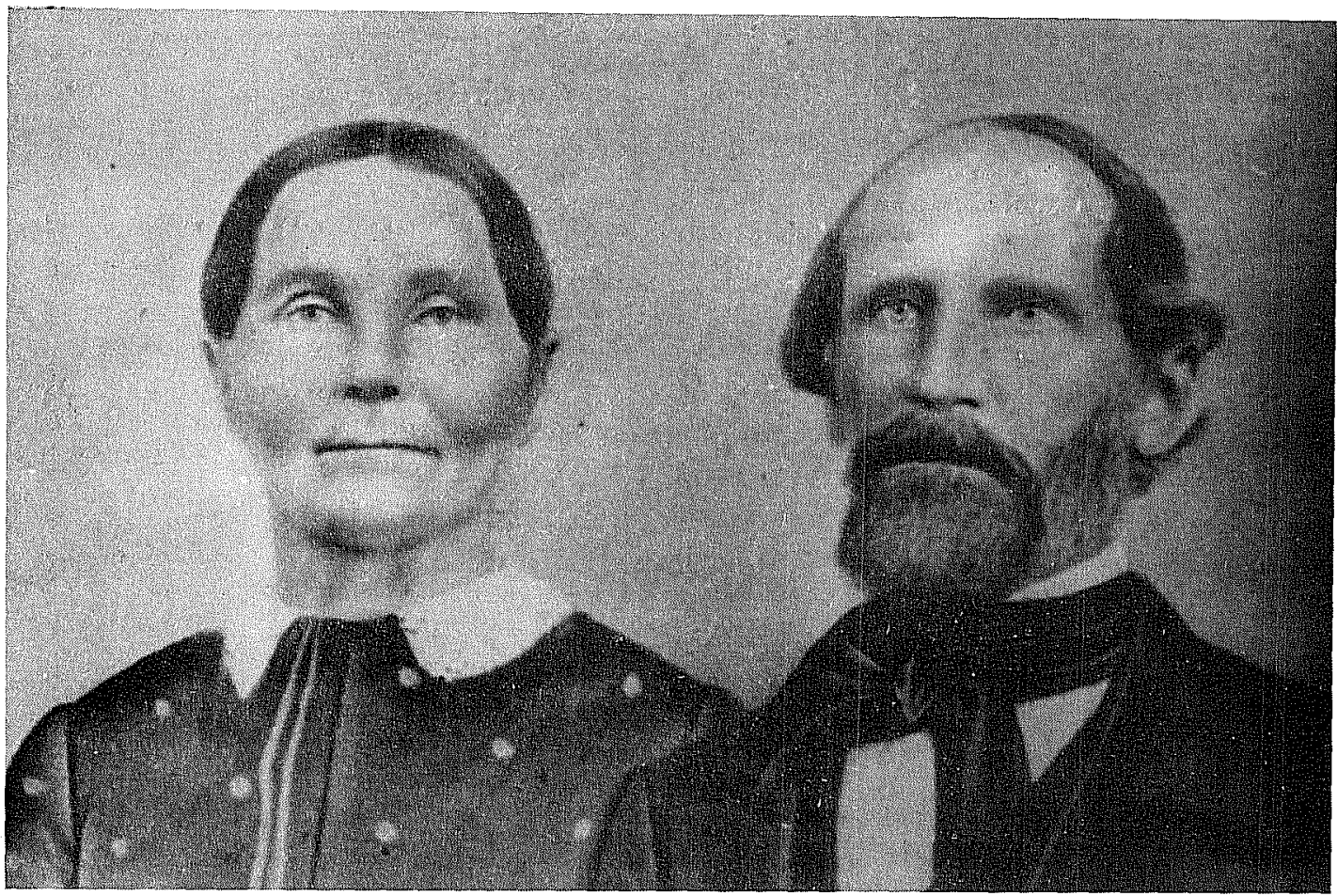

a

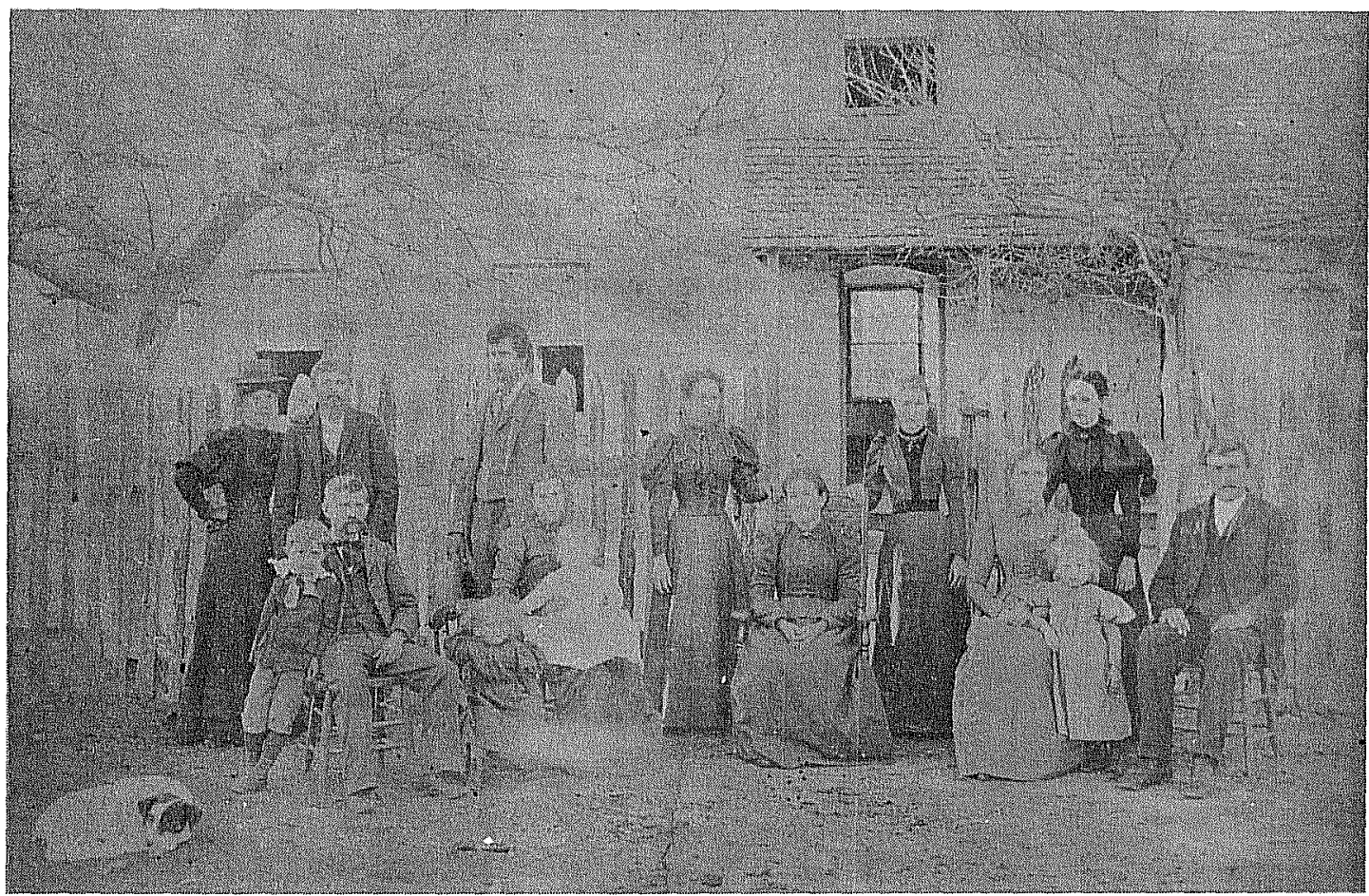

b

Figure 3. Family Photoghaphs. a, Victoria Augusta Steiner and Carl Steiner, date unknown; b, (from left to right) Mr. and Mrs. Gus Hohman; H. W. Hohman and son; Adolph Schob; Minnie Schob Hohman with son, Fred, and daughter, Augusta; Augusta Schob; Minna Steiner Schob; Biancha Steiger; Alvina Berger (seated); Emelie Hohman Reeves (child); Emelie Schob; John Berger. c. 1900 (Mrs. Augusta Sandhop). 
\$400. Steiner owned four horses, fifteen milch cows, four working oxen, twenty other cattle and fourteen swine; total value of the livestock was $\$ 700$. Animals that sold for slaughter were valued at $\$ 50$ total. In addition, 200 bushels of Indian corn and 40 bushels of Irish potatoes were raised on the farm. Two hundred pounds of butter were produced by the family for sale.

The German winemaking industry along Coleto Creek was well known and Steiner contributed to this effort (Texas Almanac 1867:111). In 1860 he produced 2000 gallons of wine from wild mustang grapes. Local tradition relates that Steiner shipped wine in barrels to Indianola to be sent to New Orleans for sale.

In $1866 \mathrm{Mr}$, and Mrs. Steiner bought a lot in Victoria, but it is not known if they actually moved into the city. That same year, however, they sold their homestead and livestock to their daughter Minna for consideration of $\$ 100$ (Deed Records 9:177). The farm may have been a dowry for Minna, as shortly thereafter she and Friedrich Schob, another German immigrant, were married.

Schob, later known as Friedrich Schob de Leon, was recorded by the 1860 Census as a laborer working on the Steiner's farm. It was common for German immigrants who could not afford to purchase land immediately upon arrival to hire themselves out as laborers until they could save enough money to start out on their own (Jordan 1966:111). Schob appears to have been in this situation. He was born in Germany ca. 1839 and came to Texas about 1851 (Self 1950). Descendants relate that Schob was trained as a tanner and worked as a cobbler with the Confederate forces during the Civil War. He was known to be a very exacting and meticulous person. He was skilled at organ and piano tuning and owned as many as three such musical instruments at one time (Self 1950).

The young couple continued to live on and farm the 40 acres.

Carl Steiner died in 1867 of yellow fever while in Victoria and is buried in a cemetery there. Sometime later Victoria Steiner died and was buried on the family property near the house. Her burial was the first in what was to become the family cemetery (Fig. 4,b). The cemetery was surrounded by a picket fence painted white except for the very top of the pickets which were painted black (Mrs. Geraldine Johns, personal communication).

Beginning in the 1870s Minna Schob de Leon bought land to expand the farm. In 1874 she bought 64.5 acres directly north of the homestead for $\$ 129$ (Deed Records 13:414). About this time, she also sold four acres to her next-door neighbor, Carl Kobitz, son of Joseph Kobitz. In 1880 she bought 151 acres directly south of the homestead from Carl Kobitz for $\$ 295.45$ (Deed Records 17:337). This brought the total acreage owned by her to 256 acres (see Fig. 1).

In 1880 Friedrich Schob de Leon started building a large stone house; two years later the house was completed and the family moved in. The structures at their old homestead were moved up to function as outbuildings in conjunction with this new house. The couple lived in the stone house until they died in the early 1920 s.

Upon Minna's death in 1923, the house was left to her granddaughters, Mrs. Augusta Sandhop, wife of Fred Sandhop, and Mrs. Emelie Reeves, wife of Claude Reeves (Deed Records 18:361). The stone house was occupied by various descendants until the 1940s. It was rented out for a short time, but after 1942 the house stood vacant. 


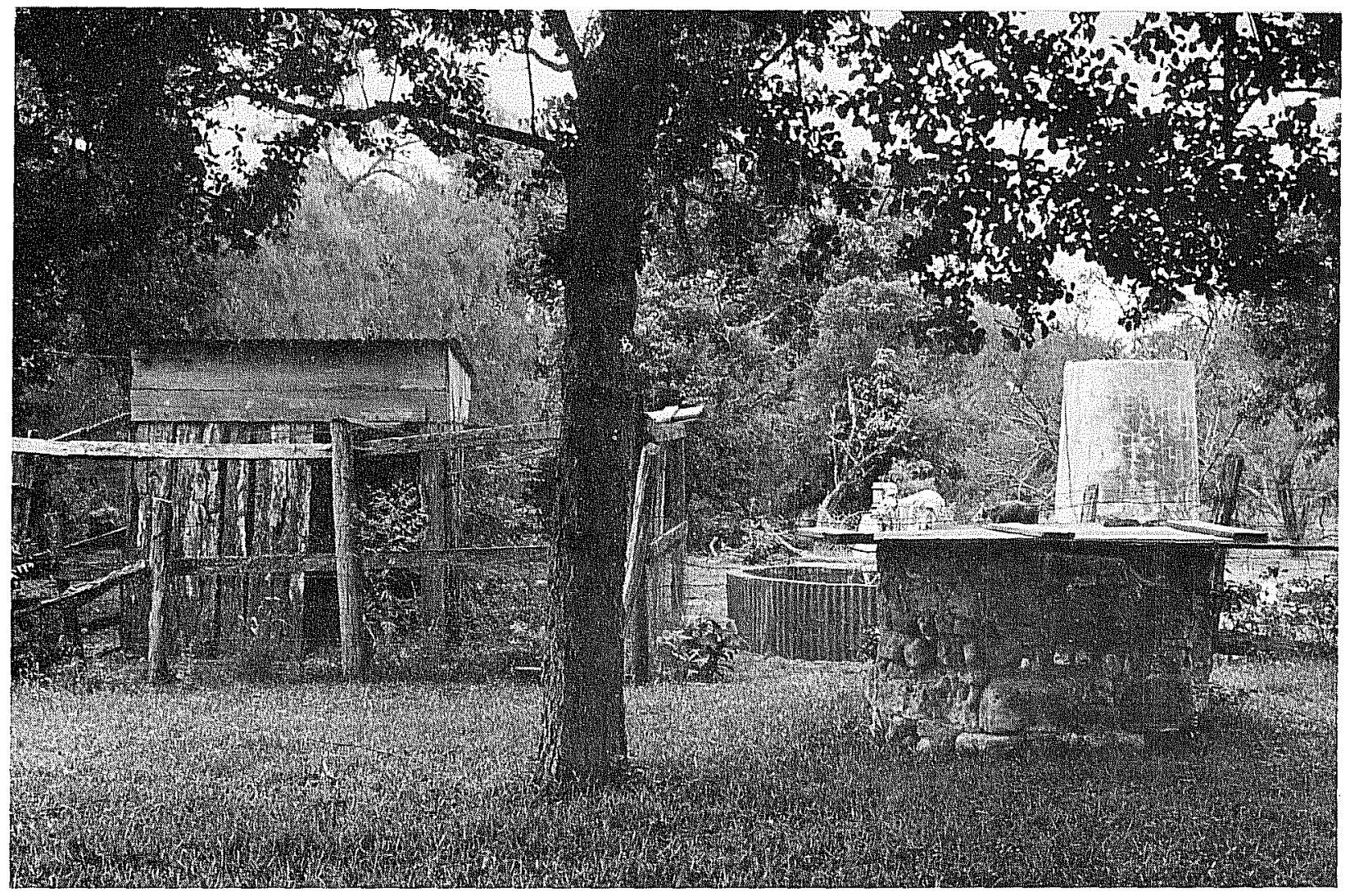

a

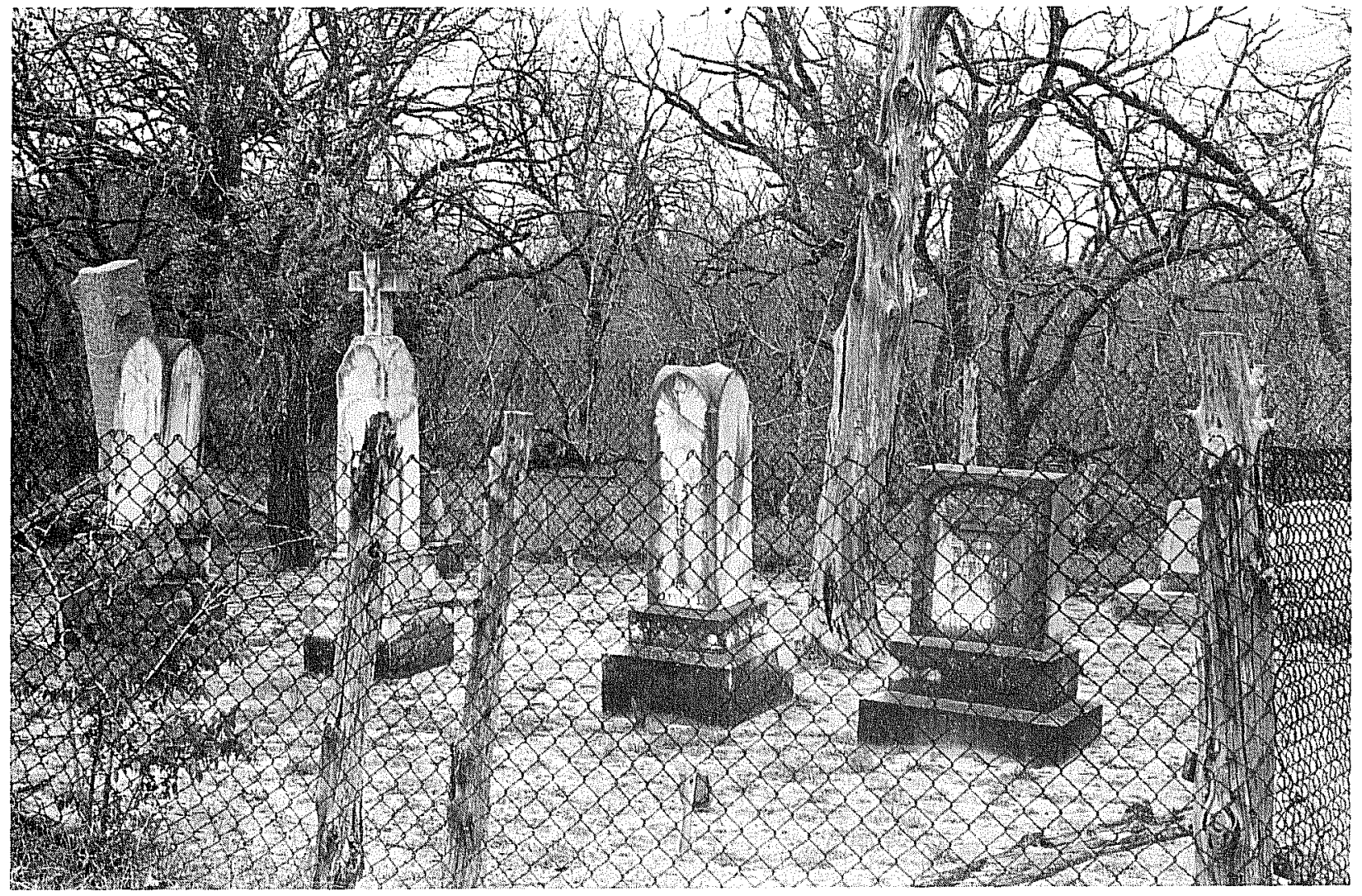

Figure 4. Outbuildings. a, Guinea house (old smokehouse?) on the left and well on the right; $b$, cemetery. 
In 1967 Charles Sandhop, great-grandson of Friedrich Schob de Leon, and his wife decided to move back onto the family property. They renovated the stone house to include modern conveniences and lived there unti1 1977, when the land was purchased by the Guadalupe-Blanco River Authority for use in conjunction with the Coleto Creek Reservoir.

\section{ARCHITECTURAL DESCRIPTION}

\section{The Steiner House/Schob Barn}

From family tradition and architectural and archaeological investigation, we have been able to gain insight into the types and locations of structures on the Steiner farmstead during the 19th century. The documented structures are a one-story frame house, a kitchen and what was possibly a smokehouse. It is very likely that other buildings existed at the time; however, within the scope of this project no evidence of additional structures was found.

Today the hewn frame house the Steiners lived in is still standing, although it has been heavily modified (Fig. 5). Only suggestions of what it was like remain. From the evidence gathered, we can surmise that the house was a two-room, onestory structure having overal1 dimensions of $25 \mathrm{ft} \times 23 \mathrm{ft} 8 \mathrm{in}$. These measurements include a porch $9 \mathrm{ft}$ wide which ran across the front of the building. The house was oriented toward the southeast, as was typical of the period, in order to catch the prevailing winds. The larger of the two rooms measured approximately $16 \mathrm{ft} \times 13 \mathrm{ft} 9 \mathrm{in}$, and the smaller measured $16 \mathrm{ft} \times 9 \mathrm{ft} 2 \mathrm{in}$. A cellar was located beneath the smaller room.

The foundations uncovered at the Steiner site verify the family belief that the hewn frame structure currentiy in use as a barn was actually used as the Steiners' residence. The stone foundations are continuous even underneath the section which corresponds to the porch. The dimensions of the cellar correspond to the smaller room of the house located directly above. There was no evidence of an exterior entrance into the cellar. Local tradition relates that the house had a trap door which led into the cellar. When the cellar was excavated, fireplace foundations which centered on the northeast wall of the smaller room were discovered.

The house used a simple framing system consisting of hand-hewn wooden members (Fig. 6). The $7 \times 6$ inch sills were mortised and pegged at the corners. They had been notched out to receive floor joists so that the top of the sill was at the same level as the top of the joists. Studs, $4 \times 4$ inches, spaced at 16 inch intervals, were mortised into the sills and into $5 \times 4-3 / 4$ inch top plates. The rafters simply rested on the top plates and were butted at the ridge. The rafters were genera17y $3-1 / 2 \times 4$ inches, although a few were small poles with the bark removed. The original nailers and shingled roof had been replaced by new nailers and corrugated sheet metal.

Examination of the existing structure reveals various transformations and modifications. Mortises evident in the sills and upper plates indicate the pattern of the original framing. From this pattern one concludes that door openings probably existed in the center of the front and back facades of the building. In two other instances, the intervals between the studs suggest additional 


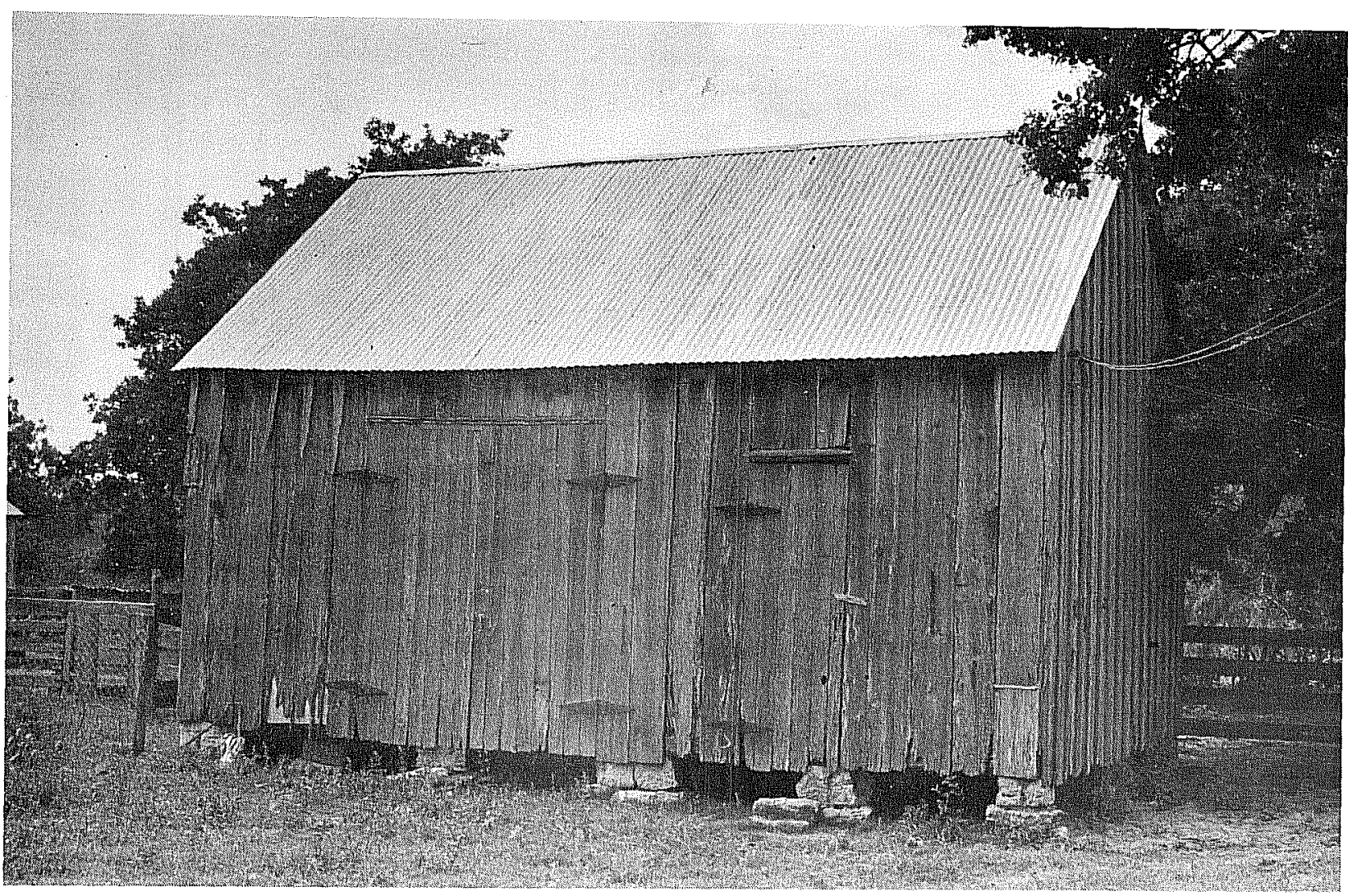

a

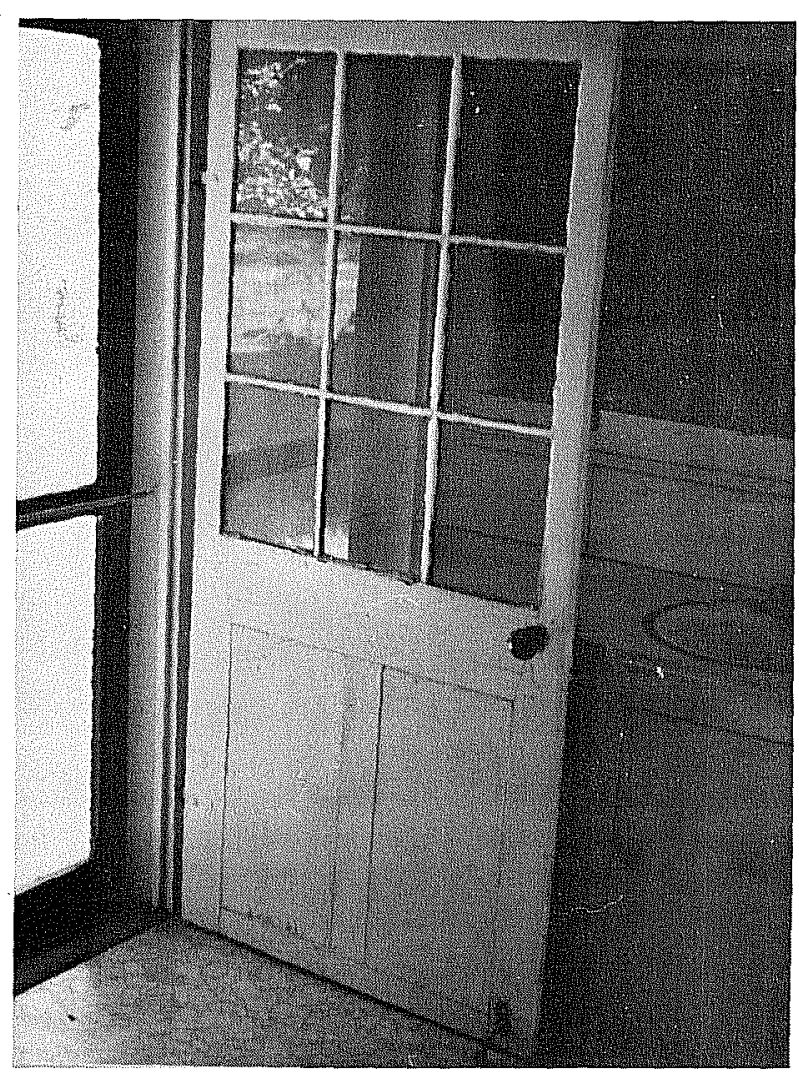

b

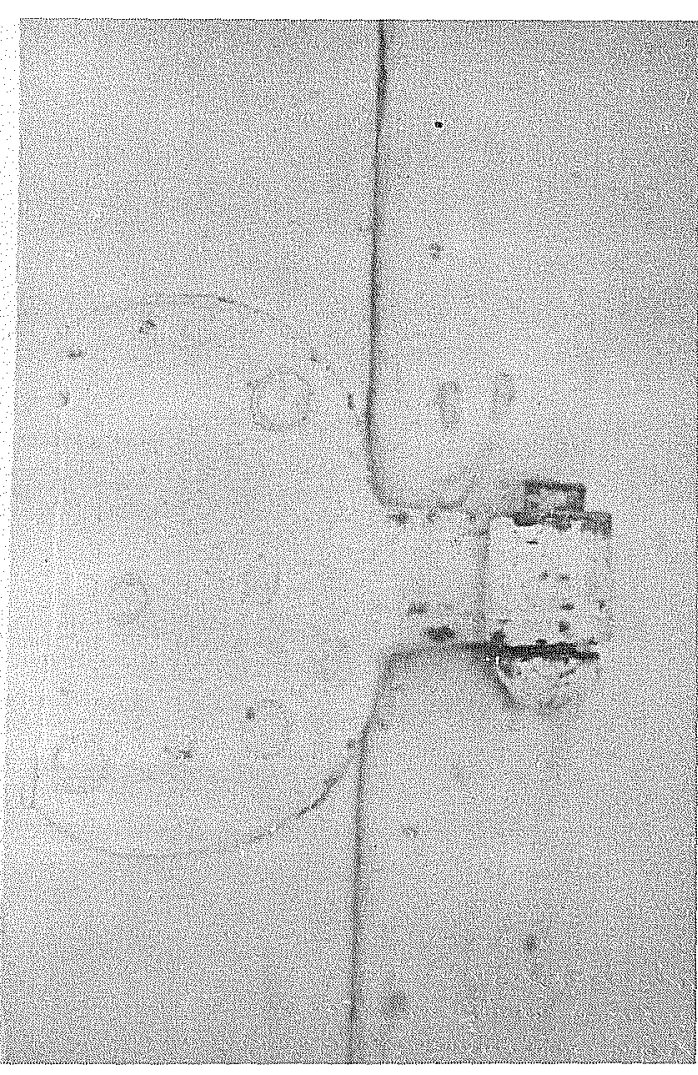

c

Figure 5. Steiner House Photographs. a, Steiner House at Schob site; b, door reported to have been used in the Steiner House; c, detail of hinge. 

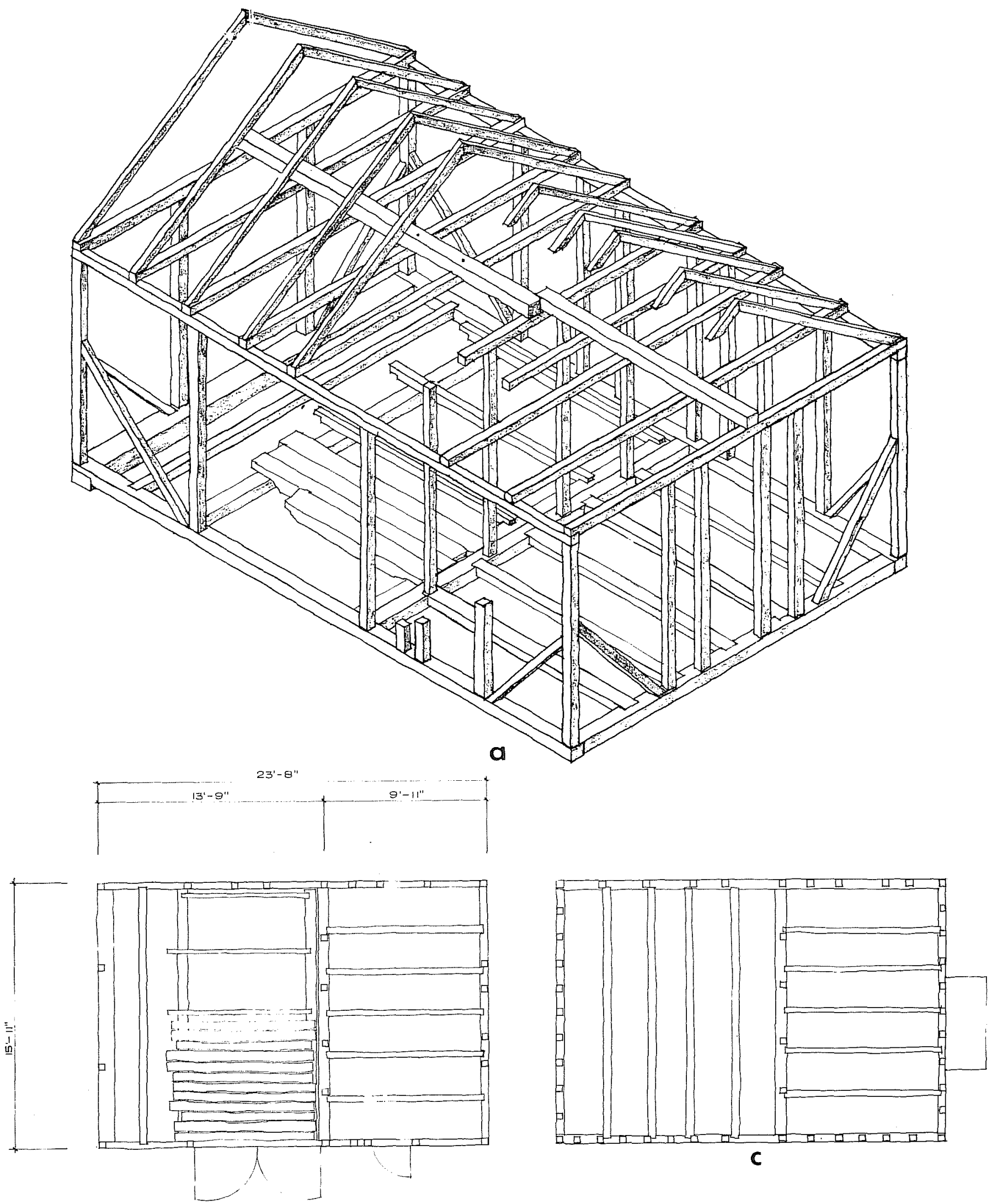

Figure 6. Steiner House Framing: a, existing framing, 1977; b, plan of existing framing; $c$, framing plan based on mortises in the sills and plates. 
openings in the wal1. However, there is no evidence to confirm this, such as mortises in the studs where window headers might have existed. The studs near the corners have not been notched out to receive diagonal bracing, indicating that these studs have been replaced or that diagonal braces were not installed originally. Removal of several boards revealed that some of the corner studs were numbered with Roman numerals. It was not uncommon to number important framing members to facilitate the initial erection of a building. On the other hand, the marks may have been made if the building was disassembled for its move to the Schob site in the 1880s.

The interior of the house appears to have been rather stark. There is no evidence of wallboard covering the interior sides of the studs. On one side of the partition wall there were numerous small tacks which suggest that fabric such as canvas may have been stretched across the studs to separate the two rooms visually. The original flooring has been replaced.

The ceiling in the small room was made in an unusual manner. The ceiling joists were approximately $5 \times 5$ inches, and on either side of each joist was a shallow groove. Short lengths of wood were fitted in the grooves in between the joists and comprised the ceiling (Fig. 7,a). In the large room ceiling boards simply rested on top of the joists. The original method of access to the attic space is unknown. Presently, boards nailed across two studs of the interior partition form a ladder to the attic.

Although the original structure was probably sheathed with horizontal siding, $1 \times 12$ inch boards and $1 \times 3$ inch battens now cover the frame. The boards and battens were probably put on after the building was moved in the $1880 \mathrm{~s}$. The kitchen at the Schob site is of similar construction. In both buildings cut nails were used to secure the wood to the studs, even though wire nails were in general use in Texas in the 1880s.

Changes were made to the structure to accommodate its use as a barn and storage shed. The family tradition relates that Mr. Schob kept the "spring buggy" in the large room, thus making the large double doors necessary. The joists and flooring under this area have been replaced many times.

A doorway was opened up from the outside into the smaller room. The family relates that Schob kept wine barrels stored in this room. A hatch from the attic space to the outside was added, and a shed for horses was added to the western end of the building at some point.

The Schob House

In 1880 Friedrich Schob began to build a two-story stone house made from stone quarried from the banks of Coleto Creek. The plan consists of two rooms side by side on the first two floors and one large attic space on the third floor. This house, like the Steiner house, is oriented toward the southeast (Fig. 8).

The overall dimensions of the stone house are $33 \mathrm{ft} 1-1 / 2$ in $\times 20 \mathrm{ft} 2-1 / 2 \mathrm{in}$. The walls are coursed limestone and vary in thickness from $2 \mathrm{ft}$ on the first floor to $1 \mathrm{ft} 6$ in on the second floor. The lime mortar used in the joists partly covers the faces of the stones. Uniform weathering of both the mortar and the stone makes 

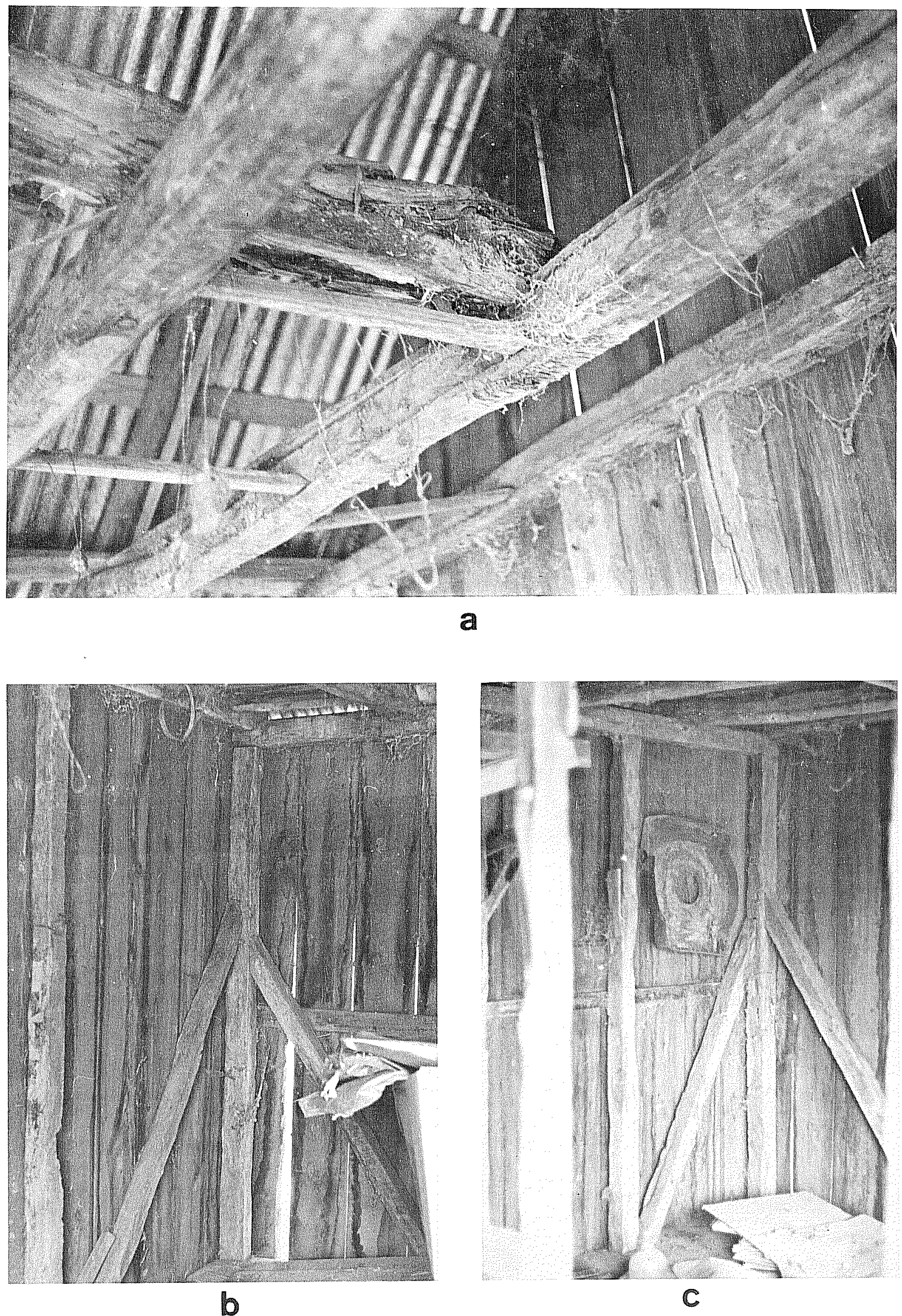

Figure 7. Steiner House Details. a, Detail of grooved ceiling joists; b, c, hewn structural members, note corner bracing. 


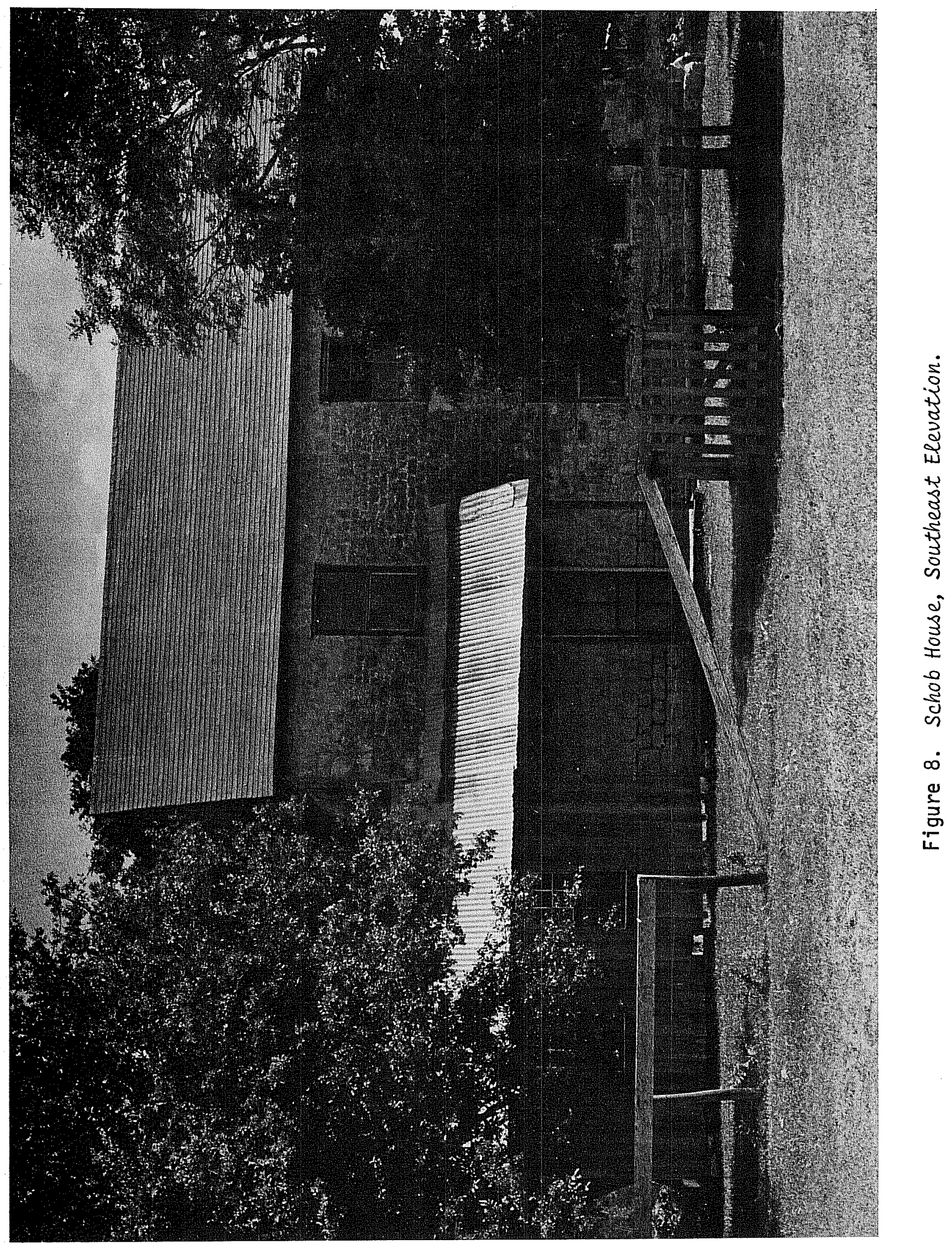


it difficult to distinguish between the two in some areas. A very thin coat of lime plaster may have covered all the stone at one time with weathering over the years producing the effect evident today. The window openings are spanned by flat arches (Fig. 9). The gable ends of the building are covered with $1 \times 6$ inch boarding (Fig. 10).

Originally, there was only one doorway into the house. The first room encountered upon entering the house is a fairly small one, measuring $12 \mathrm{ft} \times 16 \mathrm{ft} 2$ in; this room was used as a dining room. The walls in this room, as in all others, are plastered and painted white; the ceiling and ceiling joists are exposed and painted green. Off to the right is the stairway to the second floor. To the left is a doorway to the living room or entertaining room which is $15 \mathrm{ft} 5-1 / 2$ in $\times 16 \mathrm{ft}$ $2-1 / 2$ in. The ceiling and exposed joists in this room are painted blue. Flooring in both downstairs rooms is pine, $3 / 4 \times 5-3 / 4$ inch tongue and groove. The boards rest on the floor joists, which are embedded in fine sand.

The stairs to the second floor lead into a room $12 \mathrm{ft} 8$ in $\times 17 \mathrm{ft} 2$ in which contained a roller organ Steiner brought from Germany and a great pipe organ bought in 1885 from a Lutheran church. The ceiling and joists in this room were painted green. The stairway continues from this room to the attic space (Fig. 11). On the second floor was the Schob's bedroom in the adjacent room. Mrs. Augusta Sandhop remembers that the room contained a four-poster bed and two dressers. A rocking chair which the Steiners brought over from Germany also was used in this room. The ceiling is painted blue. The flooring throughout the second floor is pine, $4-1 / 2 \times 3 / 4$ inches, matched.

The large, open attic space was used as sleeping quarters for the children. The floor is pine, $3 / 4 \times 4-1 / 2$ inch tongue and groove. The attic space was not finished; that is, the rafters, nailers and shingles are exposed to the interior. The rafters generally measure $2 \times 3-1 / 2$ inches and are placed 2 feet on center. The nailers are $1 \times 3$ inches. The shingle roof was replaced many times. $A$ hatch exists in the roof to facilitate getting onto the roof for repairs.

In addition to a window in each gable, ventilation was achieved by screening the soffit where the roof overhangs the wall of the building. In winter, boards were used to cover up the screened soffit, thus eliminating unwanted air circulation.

The house was solidly built. Square nails were used throughout the house even though wire nails were commonly in use by the 1880s. Mrs. Sandhop relates that Schob was a very careful and deliberate person; she said that he would grease every nail before hammering it into place.

The stairway is simple yet elegant. The lumber is cypress and is said to have been imported through Indianola. The hardware used in the house is reported to have come from Germany (Fig. 12).

There were no fireplaces in this house. Heating was supplied by wood stoves placed in the larger room on each floor. The flue was contained within the central wall and went out through a chimney on the roof. 

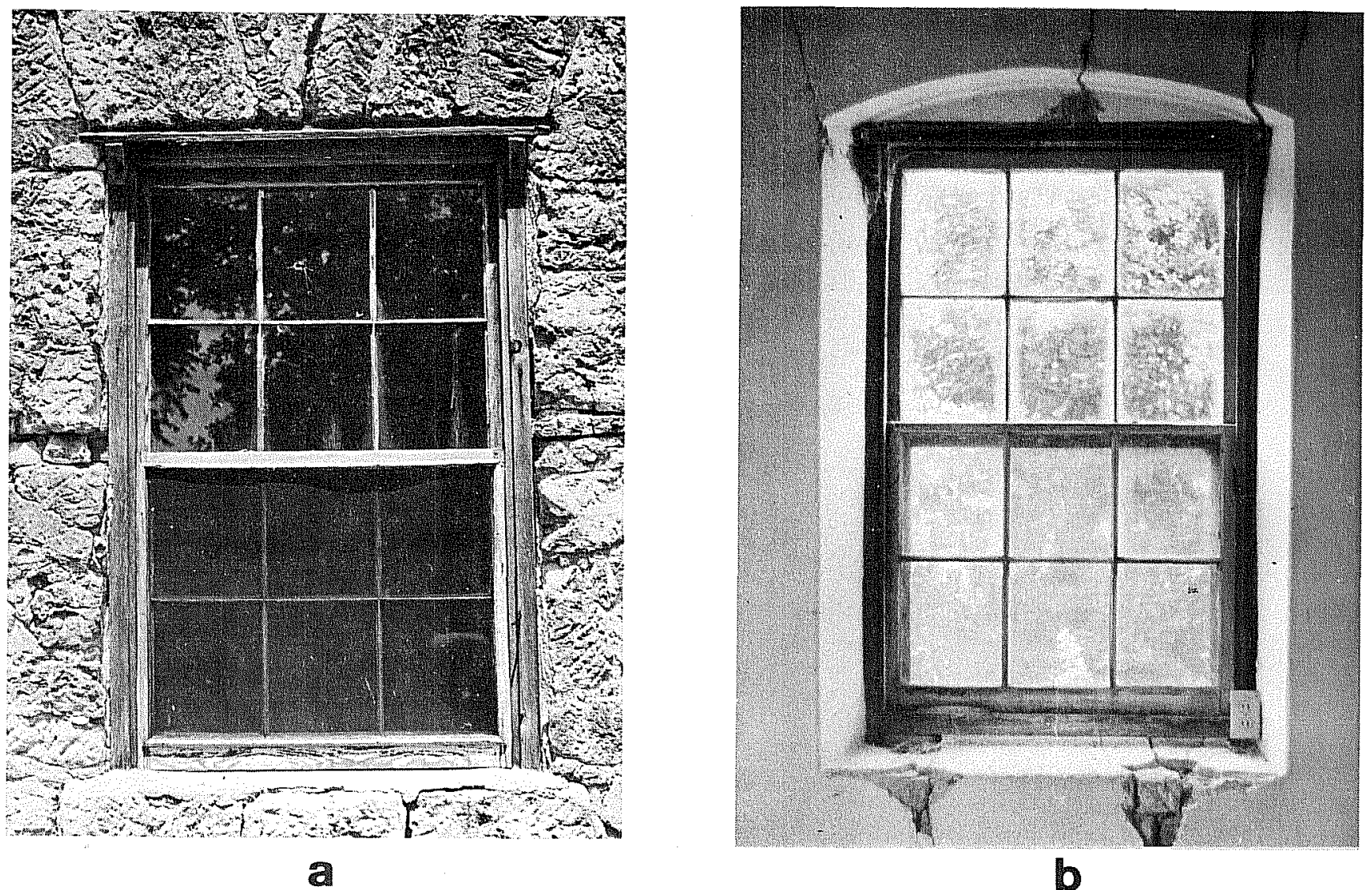

\section{b}

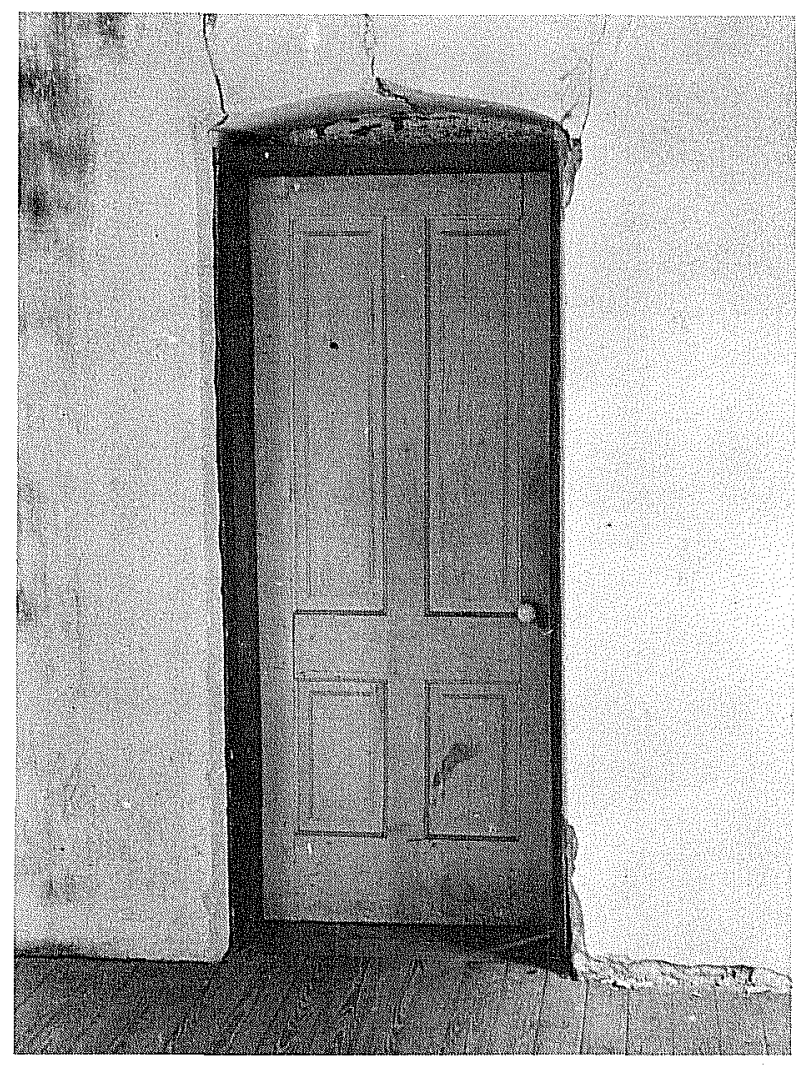

C

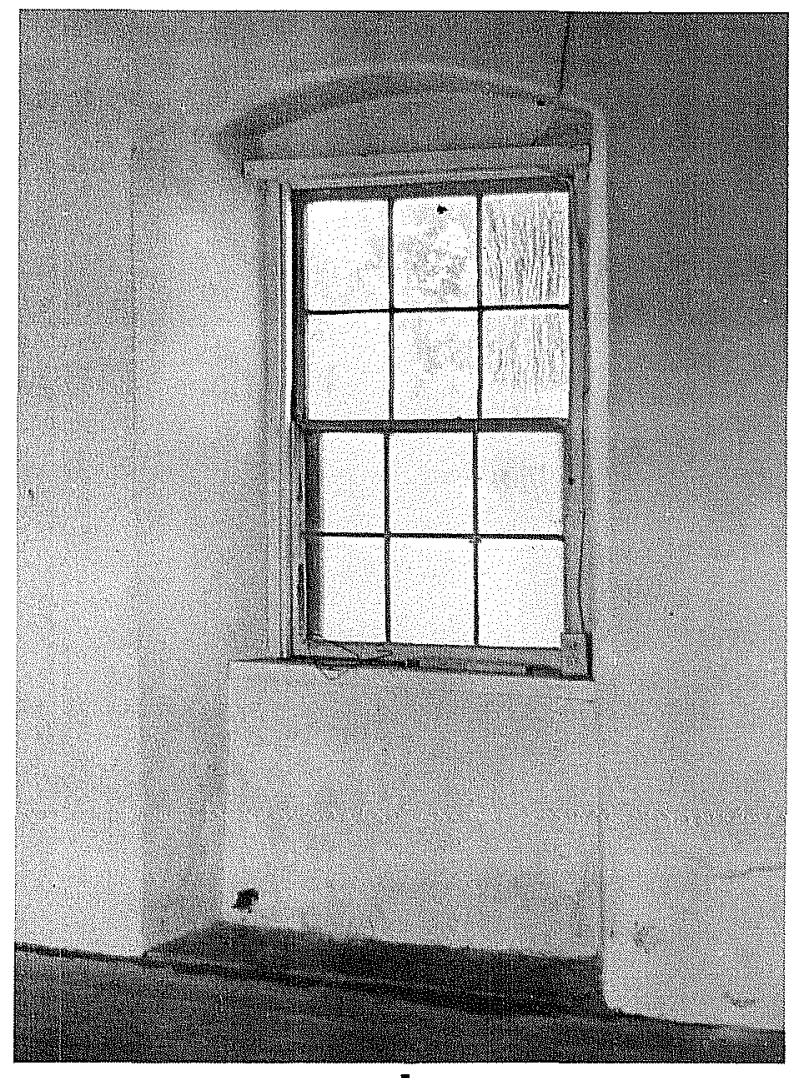

d

Figure 9. Architectural Details. $a$, typical window; $b$, window, second floor; c, doorway, second floor; d, window, first floor. 


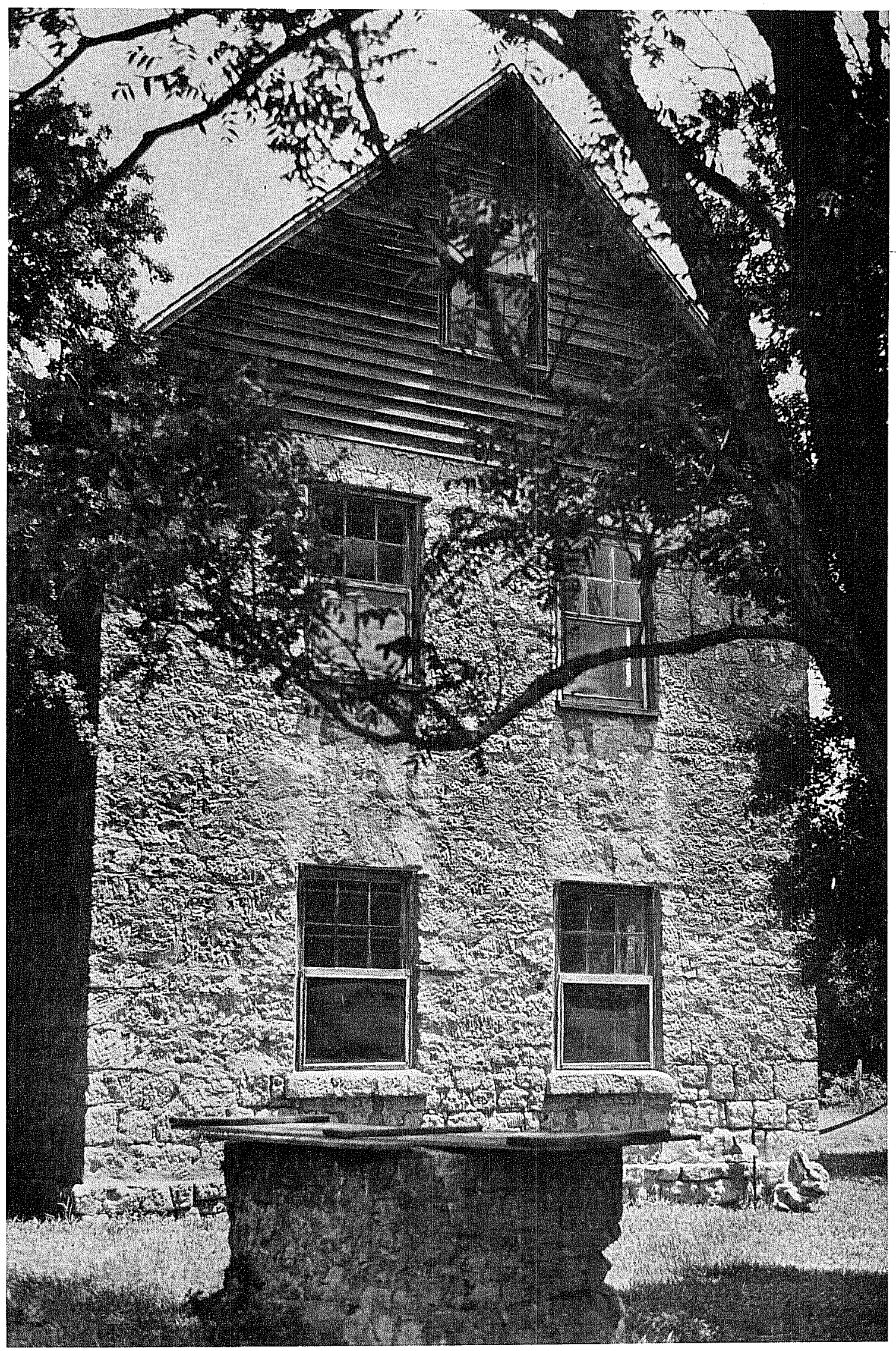

Figure 10. Schob House, Southwest Elevation. 


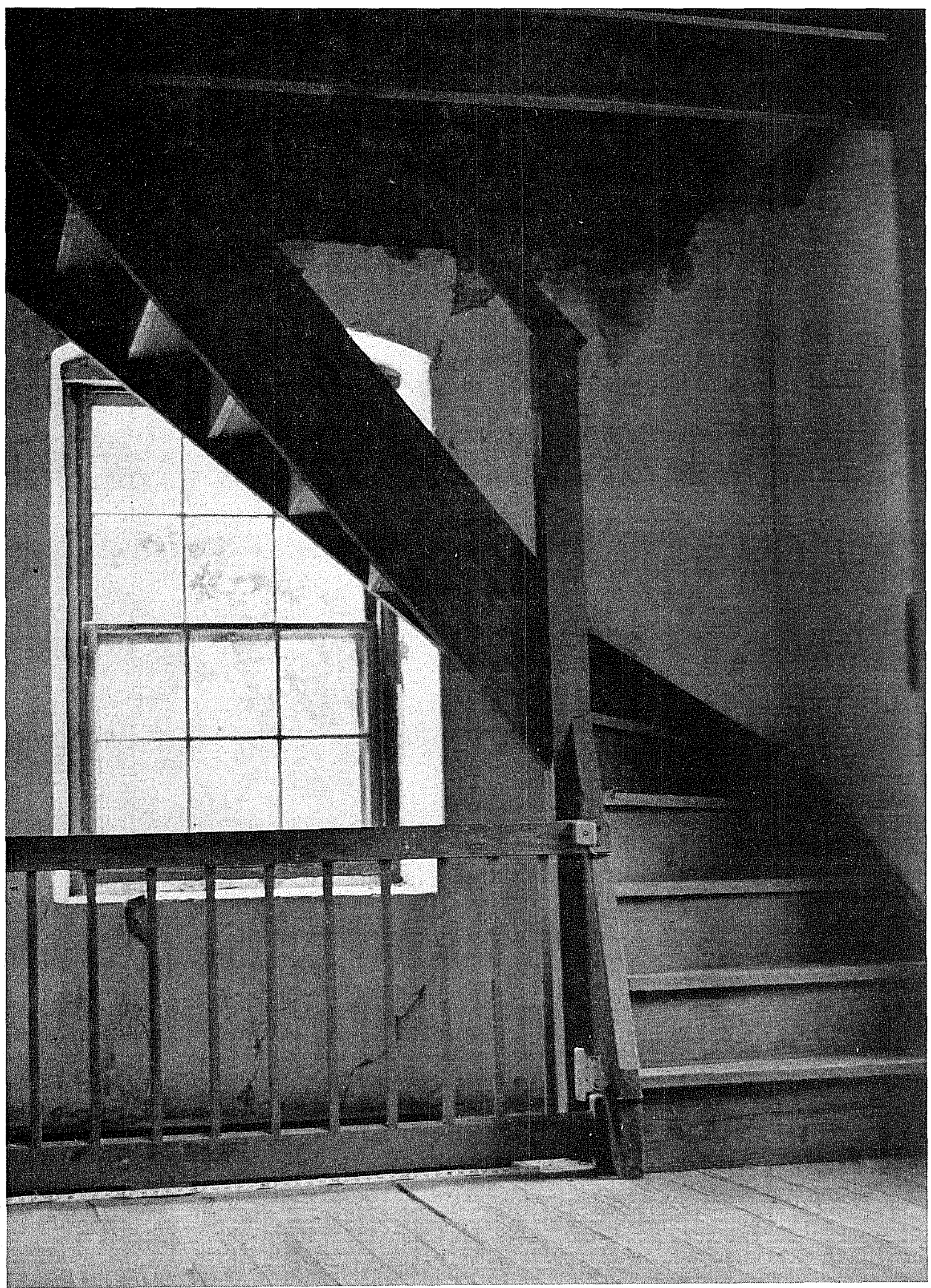

Figure 11. Interior Stairs, Second Floor. 


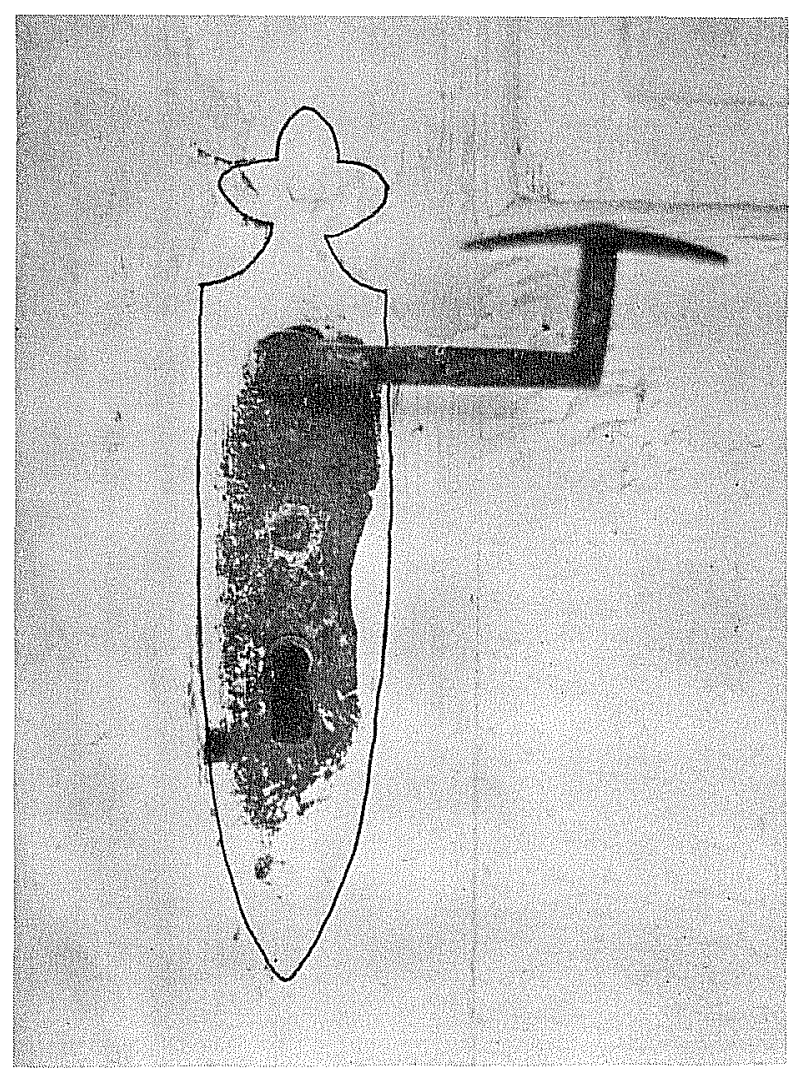

a

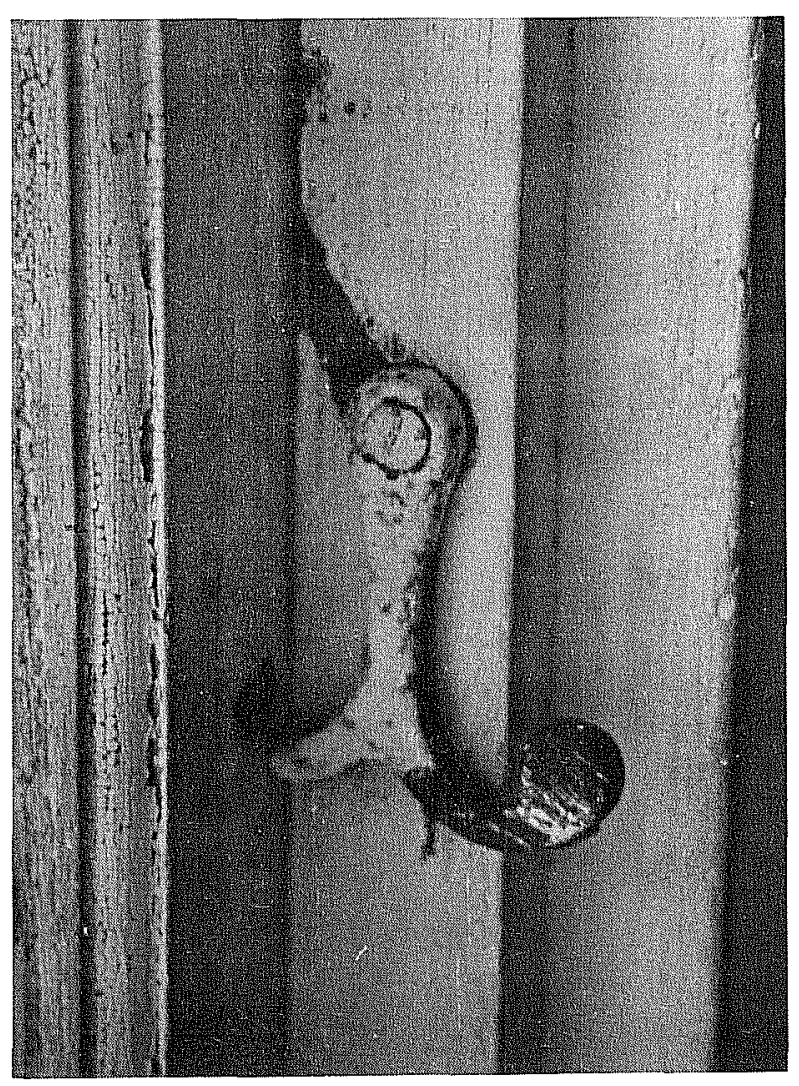

C

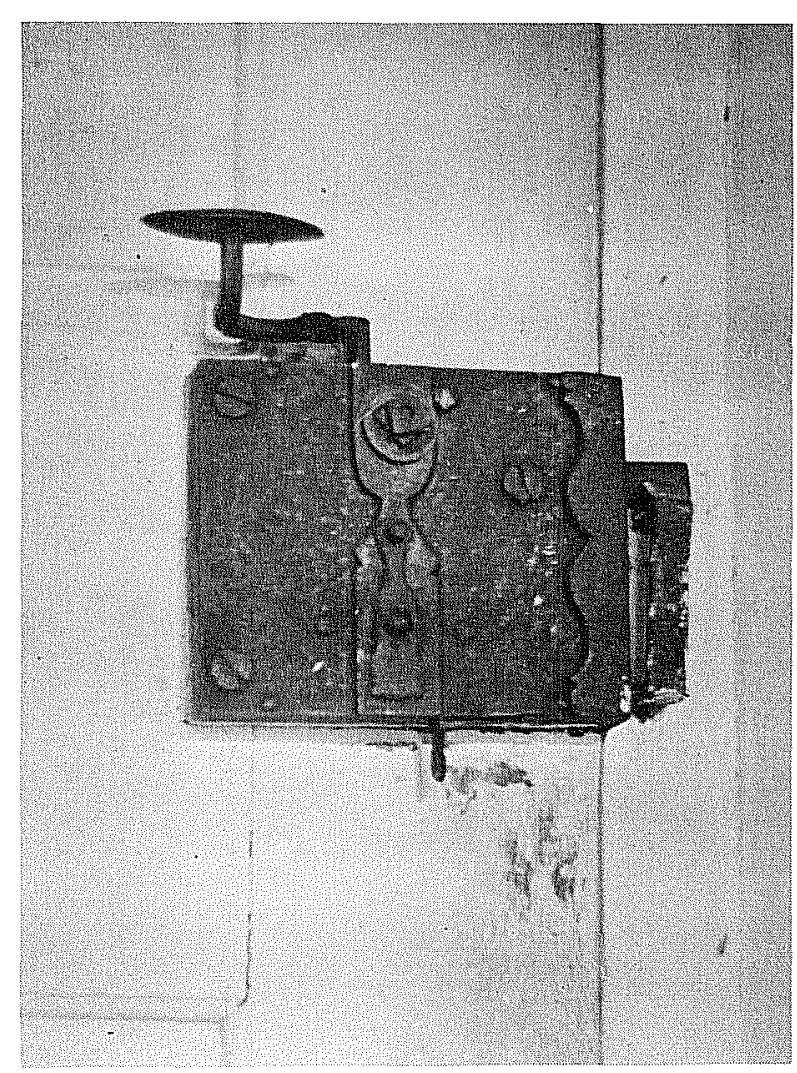

b

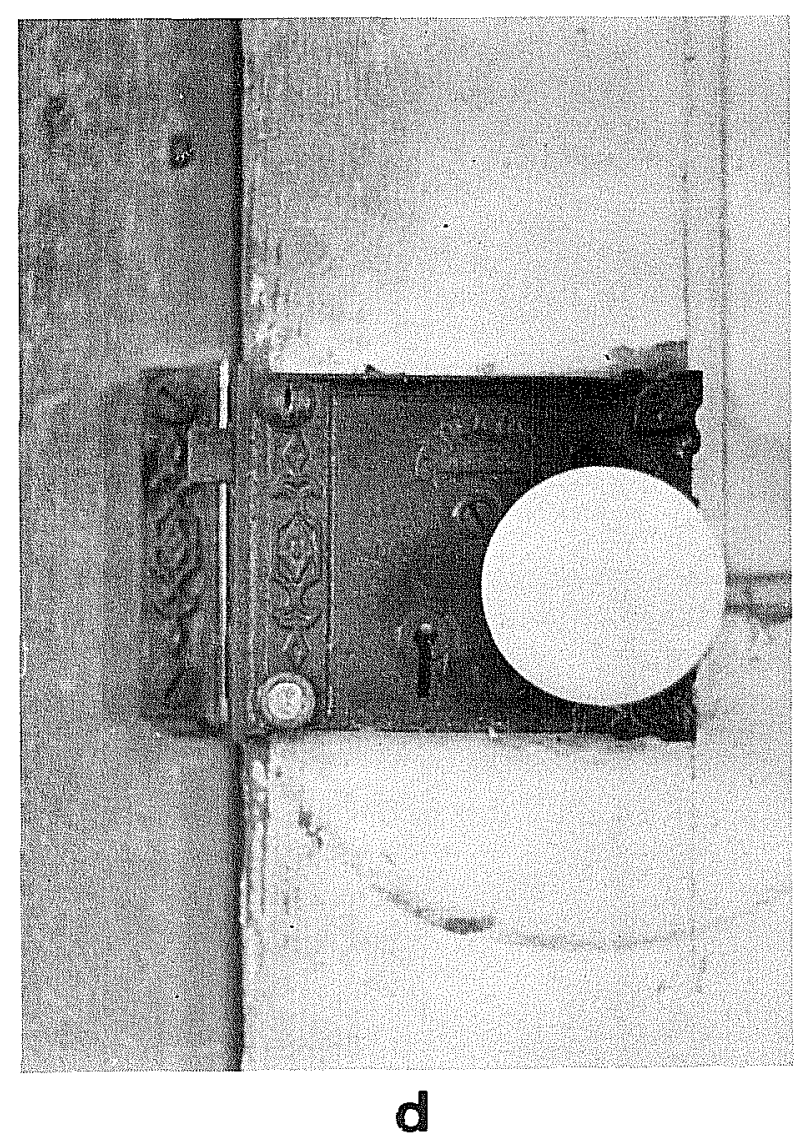

Figure 12. Hardware. a, front door latch, from exterior, 7-3/4 inches long; $b$, front door latch, interior; $c$, device to hold open bottom sash of the window; d, typical door lock. 


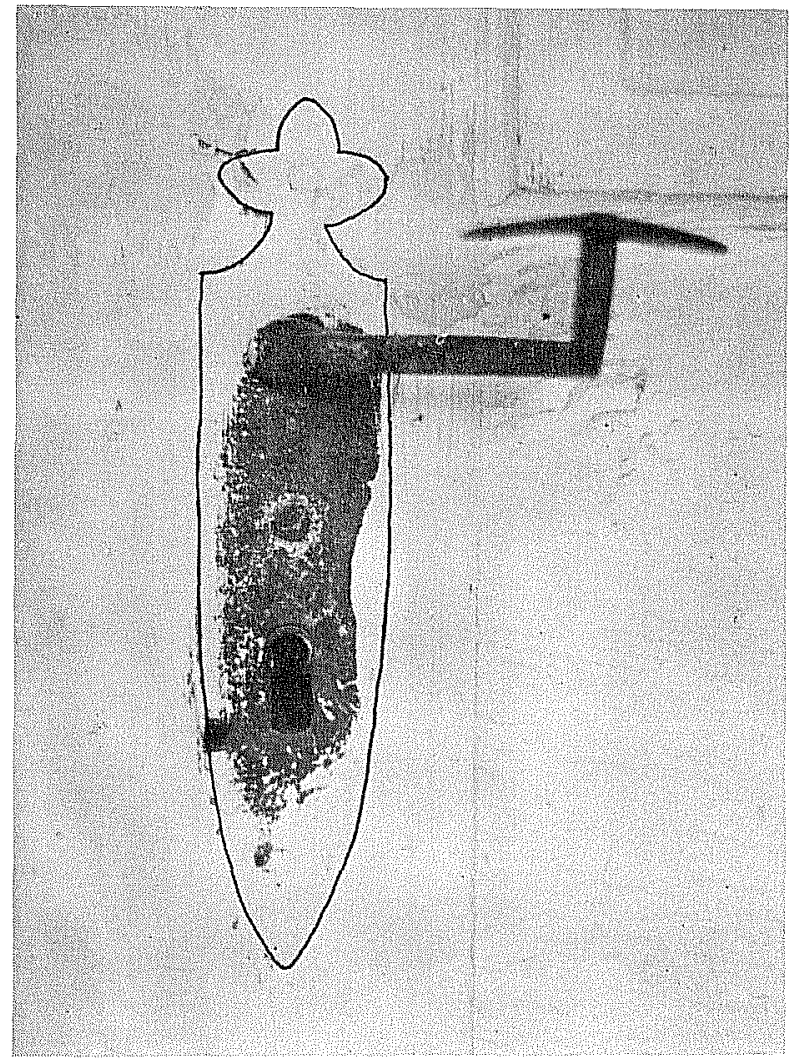

a

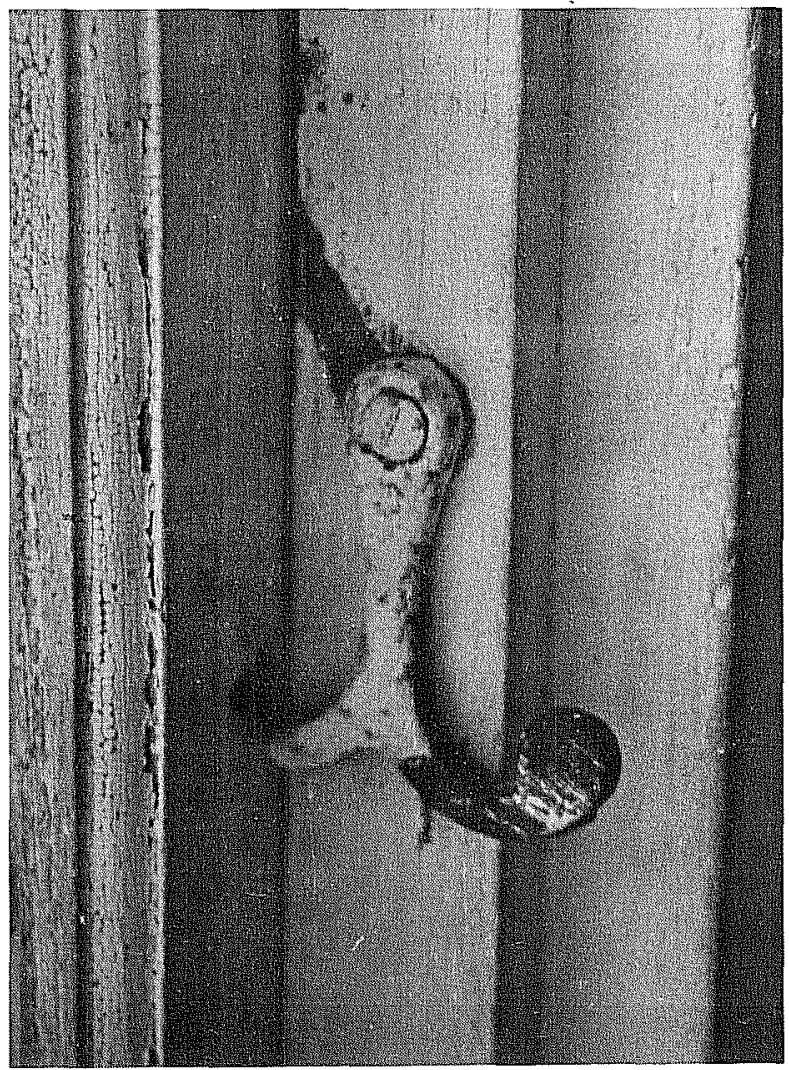

C

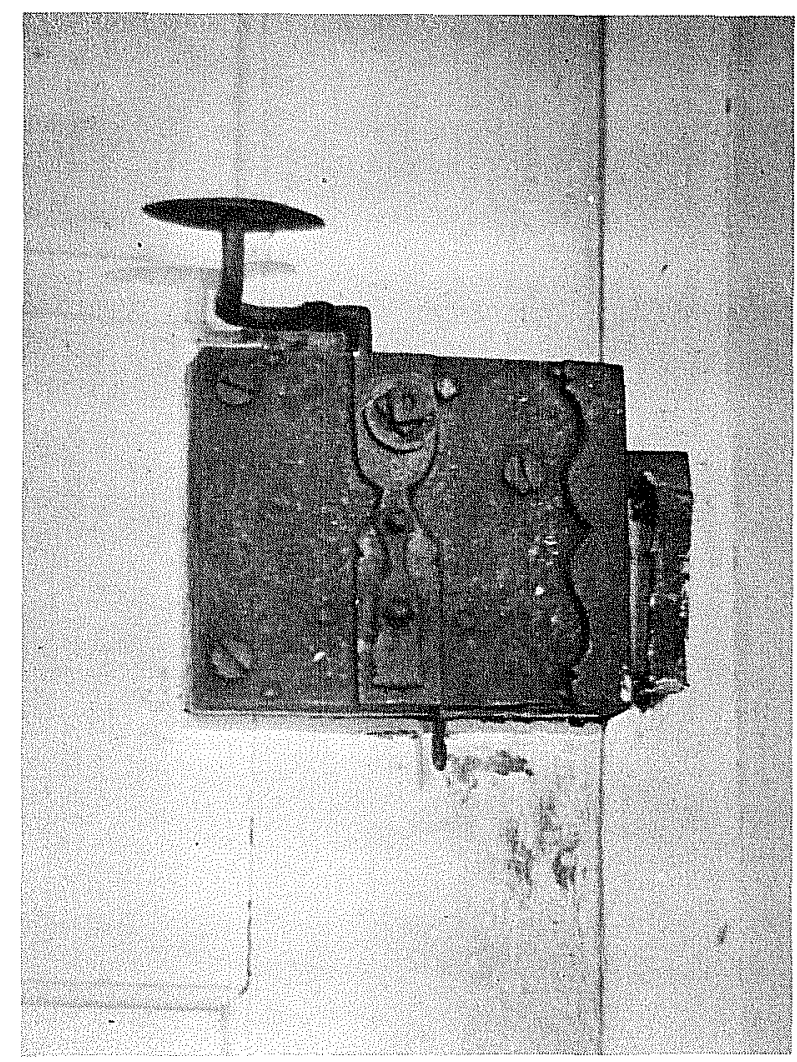

b

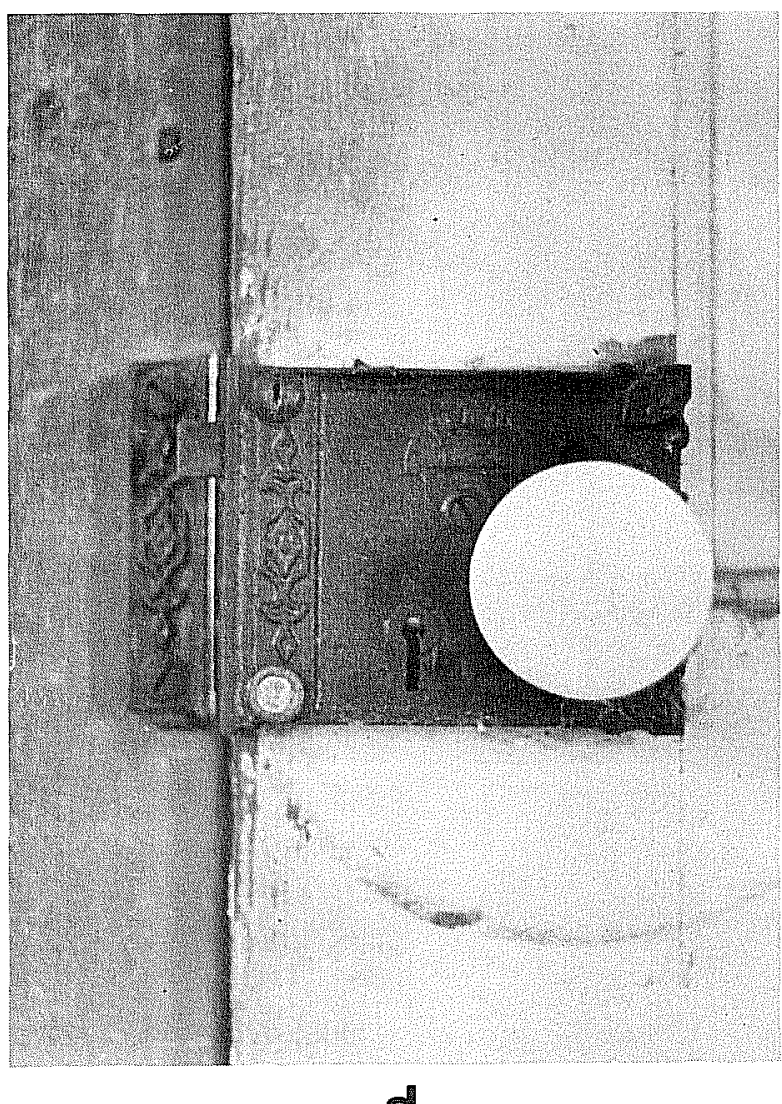

Figure 12. Hardware. a, front door latch, from exterior, 7-3/4 inches 1ong; $b$, front door latch, interior; $c$, device to hold open bottom sash of the window; d, typical door lock. 


\section{Kitchen}

The board and batten structure attached to the northeast side of the stone house was used as the kitchen. It measures approximately $16 \mathrm{ft} 2$ in $\times 14 \mathrm{ft} 7$ in. Underneath the board and batten exterior is a minimal frame of hand-hewn members which appear to have been reused from another structure.

It is not clear whether the kitchen was always attached to the stone house or if at one time it was set away from the house. Family traditions differ in opinion on this. In any case there is agreement that it was attached to the house after 1886, four years after completion of the stone house.

One of the two entrances into the kitchen is located at the front porch. The door at this entrance was constructed from two window shutters taken from a store owned by A. Goldman, Schob's brother-in-law. The back entrance on the northwest facade of the kitchen was modified during the 1968 remodeling. Two six-over-six windows exist on the southeast facade. The sash lights measure $8 \times 10$ inches and are smaller than those used in the stone house; they may have been salvaged from the Steiner house and reused in the kitchen (Fig. 13,a).

There was no interior boarding until ca. 1911 when the ceiling and interior wal1boards were installed. Until that time the framing was exposed to the interior. The flooring is $3-1 / 4 \times 3 / 4$ inches, matched.

On the northeast side of the kitchen stood a stone chimney used in conjunction with a wood-burning stove for cooking. For informal dinners the family ate in the kitchen on a large table with benches.

\section{Outbuildings}

The Schobs moved some of the buildings previously located at their old homestead to function in conjunction with the new stone house. The Steiner residence, as discussed previously, is one such building; the log structure and the guinea house may have been relocated as well.

The double log structure consisted of two rooms or "pens" separated by an open hall or "run" and was used at the new homestead for storage of corn. Each room measured approximately $12 \times 8 \mathrm{ft}$ and the hall was $10 \mathrm{ft}$ wide. The structure was supported on sandstone piers. The logs were joined at the corners with a half-dovetail notch. It is unknown whether or not this structure was moved up from the Steiner site. High winds that accompanied the 1942 hurricane heavily damaged one pen and the other was virtually destroyed. The logs in the room that is still standing appear to have been restacked at some time (Fig. 14).

Family tradition relates that the small building last used as a guinea house was the smokehouse that had been brought up from the Steiner site. The archaeologists uncovered foundations that roughly approximate the size of the existing smokehouse; however, a connection between the two cannot be ascertained. The existing smokehouse had its shingled roof removed and a flat roof installed ca. 1969 (Fig. 4,a). 


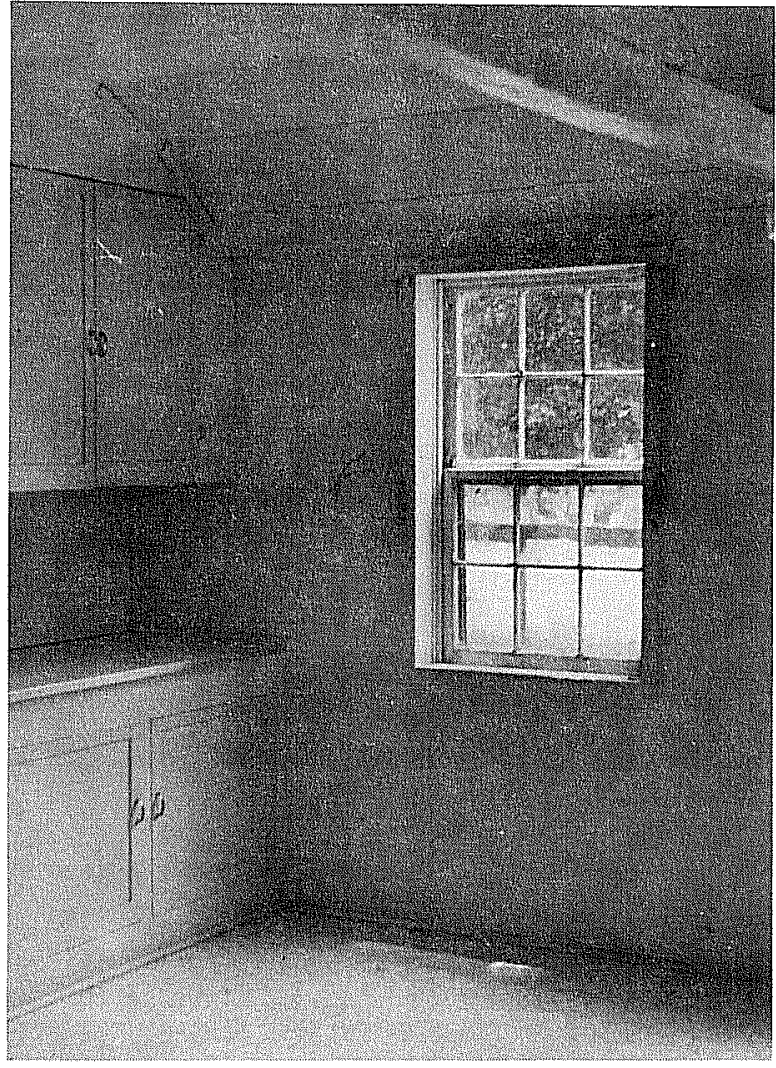

a

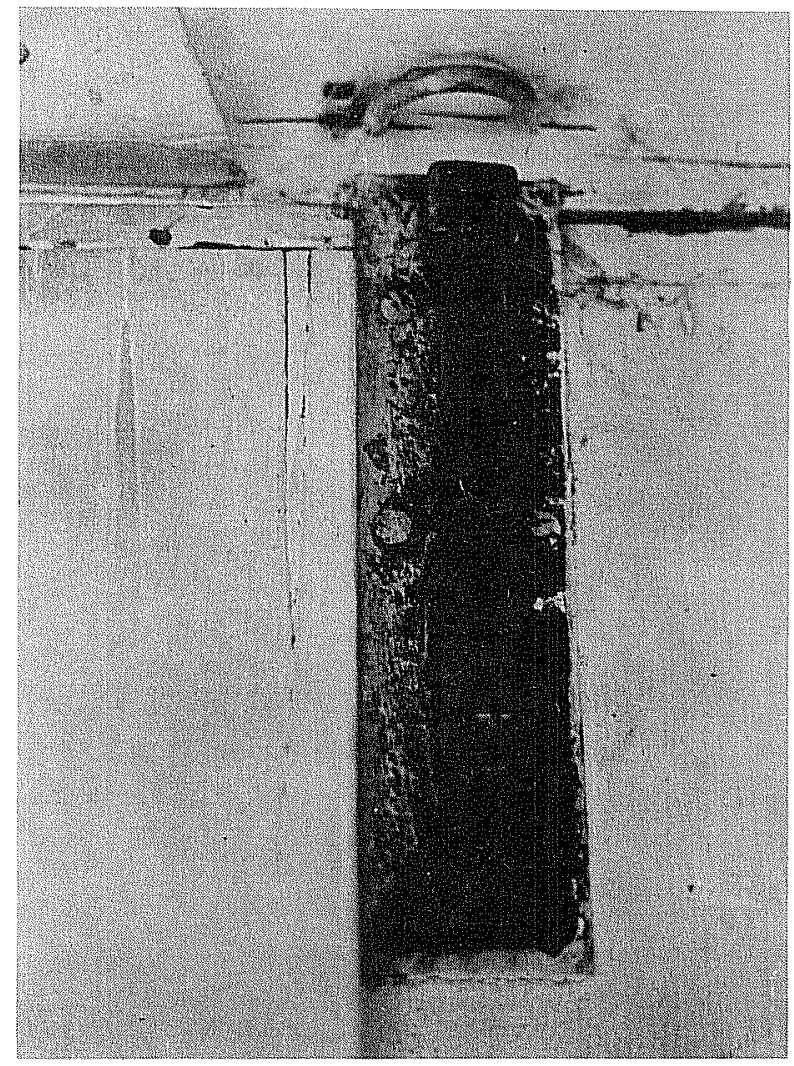

b

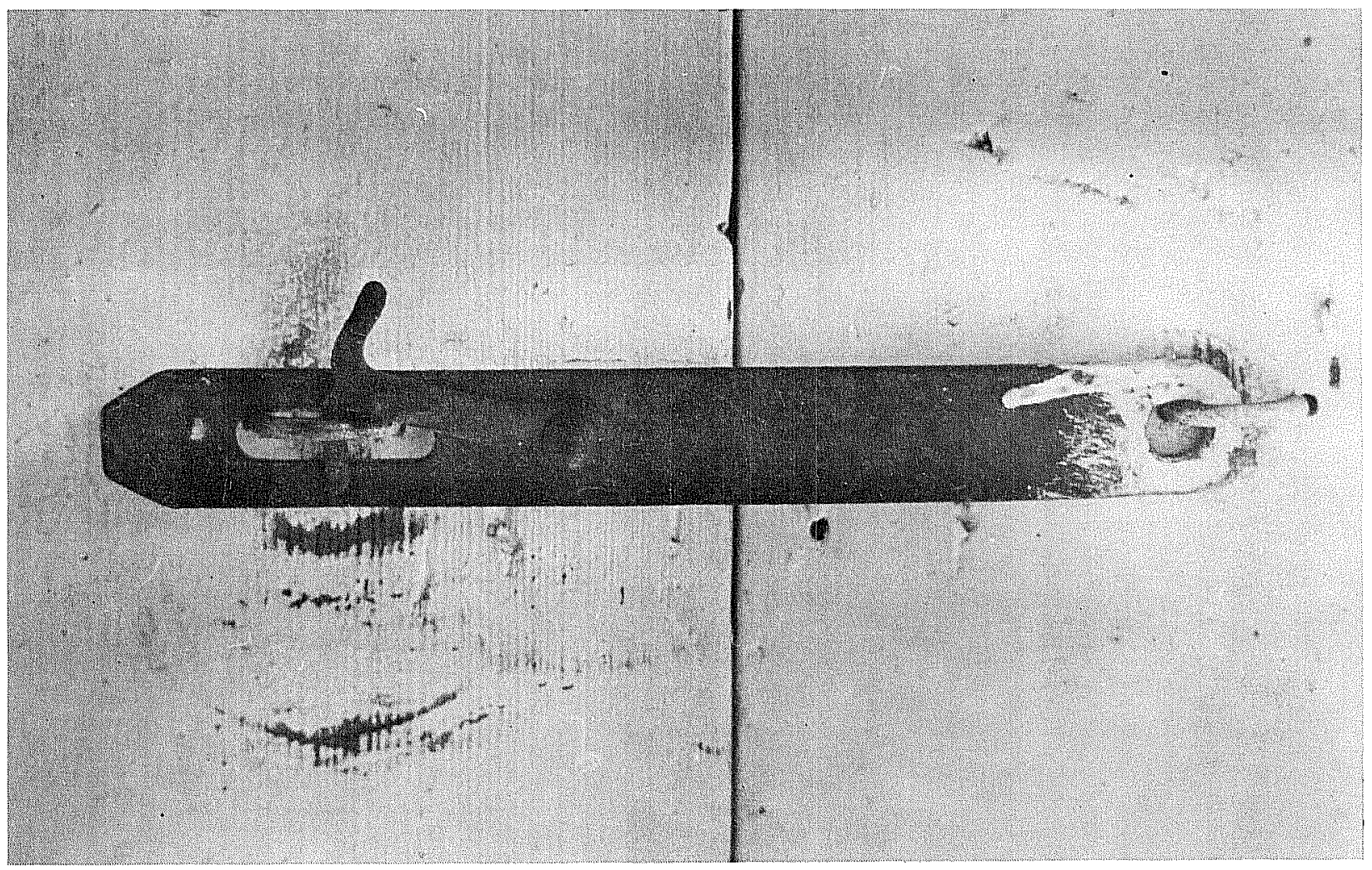

c

Figure 13. Kitchen Details. a, interior view of kitchen; b, 8 inch latch on interior of kitchen door; $c, 8$ inch latch on exterior of kitchen door. 


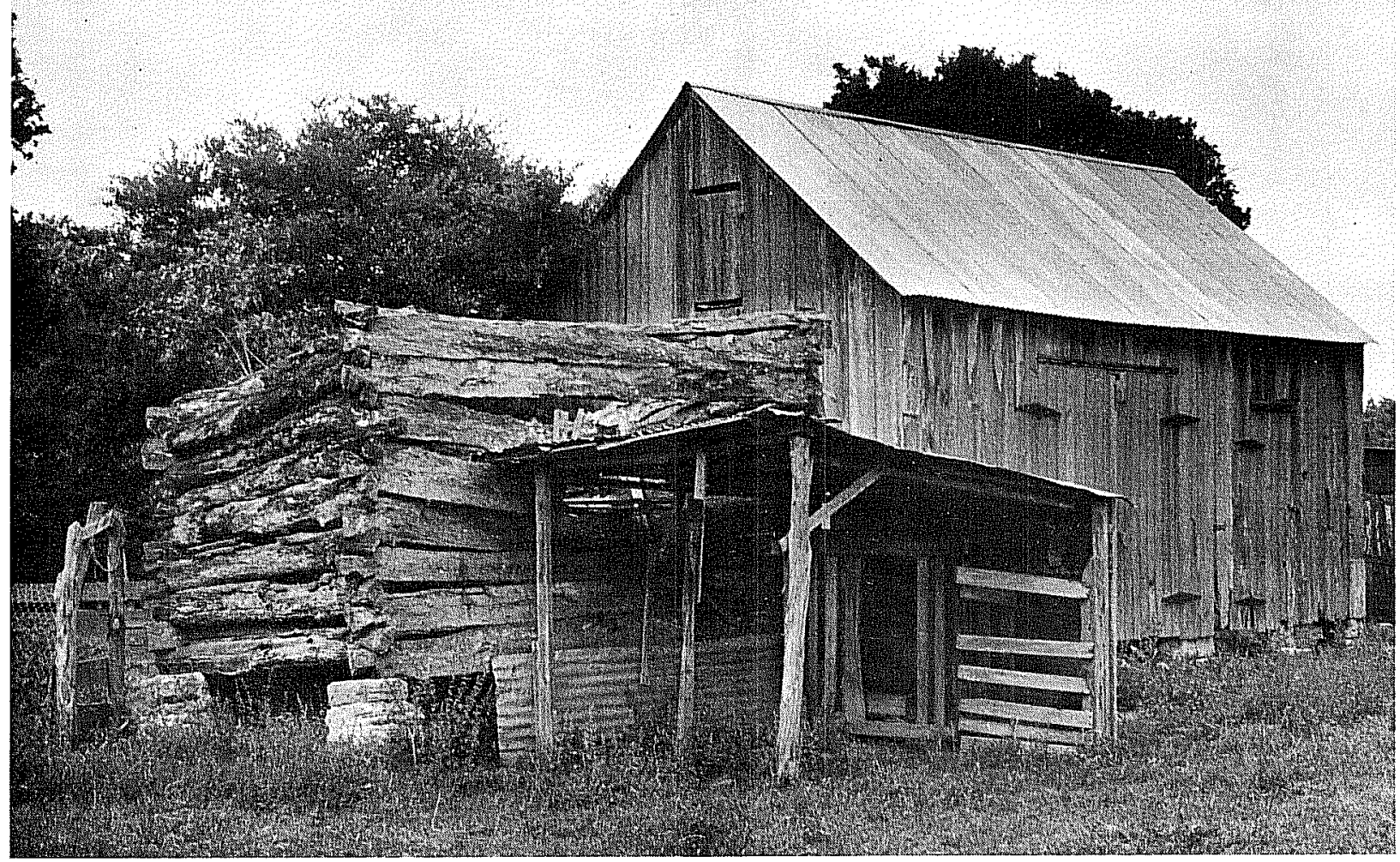

a

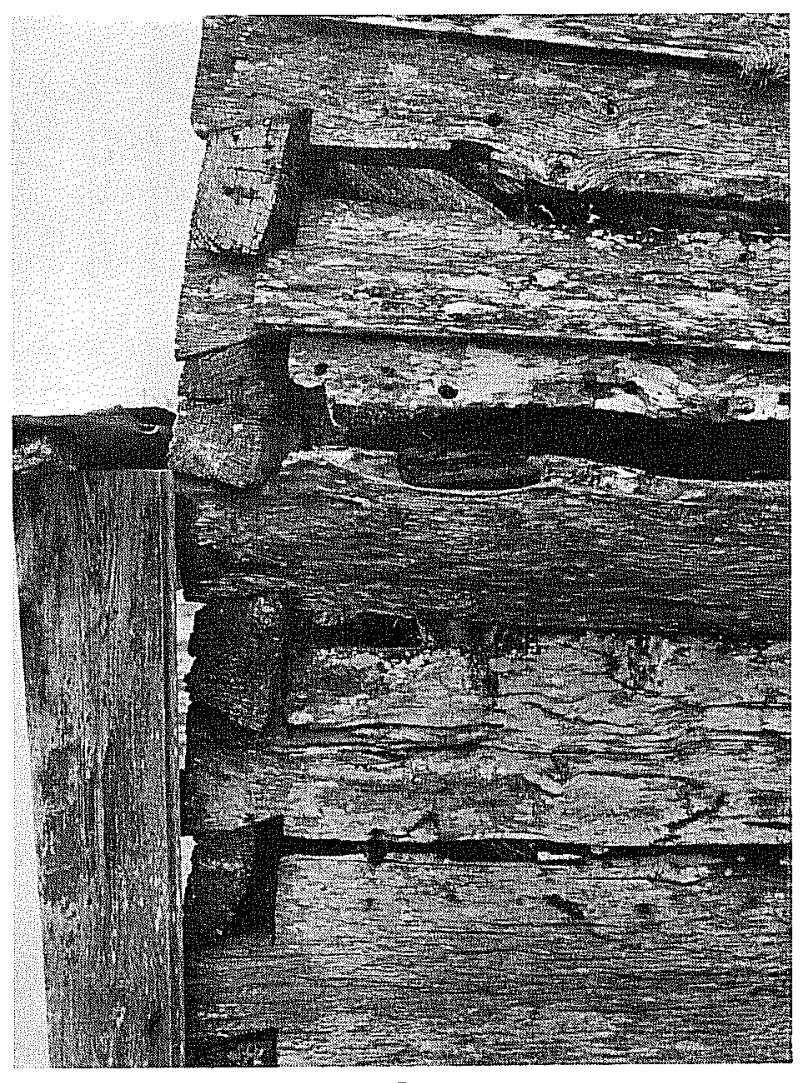

b

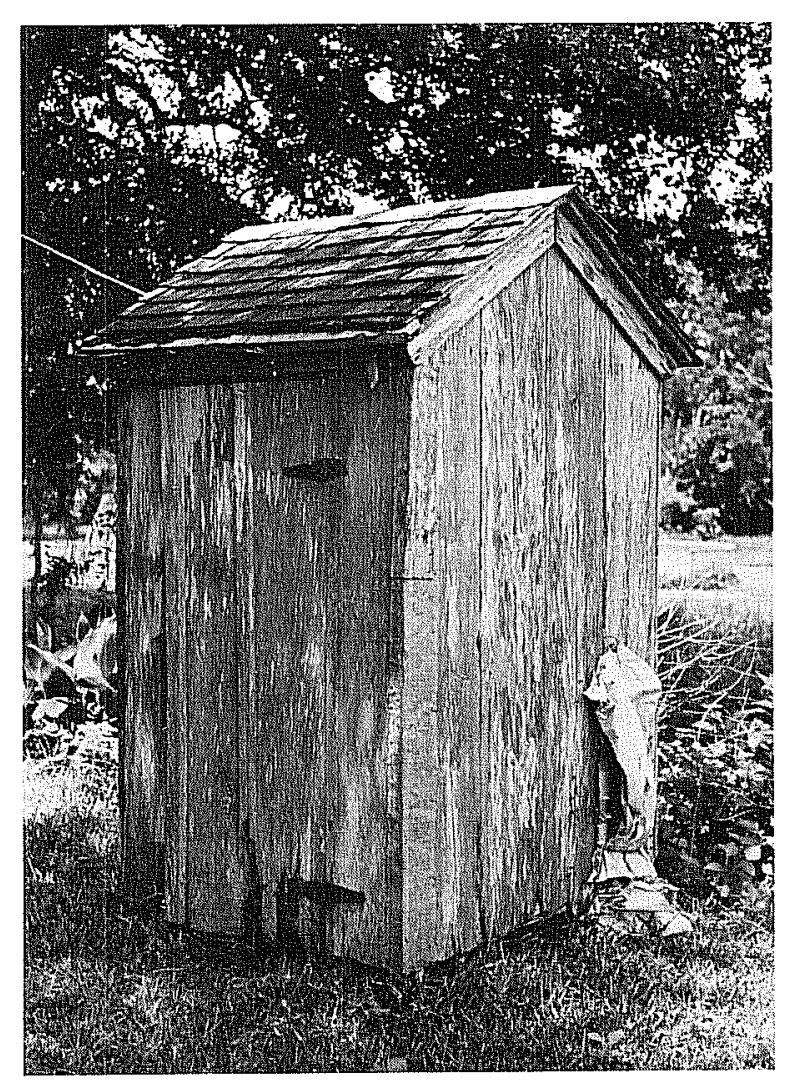

C

Figure 14. Outbuildings. a, remainder of double log structure with Schob barn in rear; b, detail of log notching; $c$, outhouse. 


\section{0ther Improvements}

Water for the homestead was furnished by a dug well 1 ined with sandstone. Mrs. Sandhop reported that at one time a well house stood over the well and contained a bucket and pulley system to raise the water.

In the 1940s a steel windmill and tank for cattle were installed.

An outhouse was located southwest of the house. During the 1967 renovation this structure was moved up close to the kitchen and housed a washing machine (Fig. 14,b).

A tall rail fence surrounded the house proper. This fence is shown in photographs dating from the turn of the century. Family tradition relates that inside the fence the yard was kept bare, except for a few rows of tobacco planted by the kitchen. The vegetable garden was planted north of the house near a slight depression in the ground that held water for irrigation purposes. A garage building was built southwest of the house.

\section{Recent Renovation}

The farm buildings were vacated during the 1940s and remained empty until 1967 when Mr. and Mrs. Charles Sandhop decided to renovate the buildings for their use. Much effort was required to return the structures to working condition.

The stone house had no plumbing or electrical fixtures. A shed room, $10 \mathrm{ft} 8 \mathrm{in}$ $\times 14 \mathrm{ft} 4 \mathrm{in}$, was added off the kitchen to house the necessary plumbing. The interior wall surfaces on the first floor were replastered and painted white.

Over the years the shingle roofs on the kitchen and many of the outbuildings had deteriorated, resulting in heavy damage to the ceilings below. Mr. Sandhop put a new sheet metal roof on the kitchen and installed acoustical tile over the tongue and groove ceiling boards. In remodeling the kitchen he also added new cabinets and a sink. He removed the chimney for the cooking stove and installed a window in that location.

The roof on the barn was replaced with a new sheet metal one; the old rafters were reinforced with new lumber; and the old wooden garage was torn down and the lumber used to build a small storage shed. From time to time, metal barns were added as needed to care for the cattle that grazed the land. 


\section{ARCHAEOLOGICAL INVESTIGATIONS}

\section{INTRODUCTION}

Archaeological research at the Steiner-Schob complex was carried out during May 1977 by a crew of six archaeological students and graduate archaeologists under the direction of the author. During the planning phase of the project, reports from archaeological excavations completed on other German sites were consulted, and numerous publications on the German settlers in Texas were read. From this research the following objectives were formulated for the project, in addition to the main objective---to reconstruct a plan of each site as it was originally built and occupied.

The project should accomplish the following:

1. Contribute significantiy to a reconstruction of life on a south Texas German immigrant's farm from 1850 to 1920.

2. Determine, if possible, in what manner and at what rate acculturation was accomplished, as reflected in the archaeological record.

3. Examine artifactual content and distributional patterns, wherever possible, for comparison with other excavated 19th century sites.

\section{PREVIOUS ARCHAEOLOGICAL WORK}

Comparatively 1ittle professional archaeological work has been published on 19th century German sites in Texas. Most prominent publications have been on the work at LBJ State Park (Tunne 11 and Jensen 1969), which recorded homesteads dating to the 1860s and 1870s near Stonewal1 in the Texas Hill Country, and the Biegel settlement (Carter and Ragsdale 1976), done at homesteads built in the 1850s near La Grange in Fayette County.

Archaeological investigation has been conducted at 19th century Anglo-American sites in the Victoria area, notably those historic sites within the Palmetto Bend Reservoir (Ma1louf, Fox and Briggs 1973) and the Cuero I Reservoir (Fox et al. 1974). Excavations at Presidio La Bahia at Goliad produced a collection containing a large 19th century component, but unfortunately a report of these excavations has not yet been published. A collection of ceramic sherds from 41 VT 14, a house site north of Victoria on the Guadalupe River occupied between ca. 1840 and 1860, is in the author's possession.

\section{METHODOLOGY}

Standard archaeological procedures were followed throughout the project. Excavation was done with shovels and trowels, with soil passed through 1/4-inch screens, except where this was deemed unnecessary. A daily log was kept, and standard excavation forms were used. In addition, numerous detailed excavation drawings and photographs were made, and maps of each site were drawn with the aid of an alidade and plane table. The overall base map of the complex was kindly 
provided by the Guadalupe-BTanco River Authority. A11 measurements were made in feet and inches, after it was determined from comparative dimensions of buildings that the Steiner and Schob houses had been built in that mode. Artifacts were cleaned and catalogued at the Archaeology Laboratory of the Center for Archaeological Research. A11 original maps, records and drawings are on file at the Center.

\section{THE SCHOB SITE}

In planning the archaeological work at the Steiner-Schob complex (Fig. 15), it was decided to begin at the Schob site, where a number of structures were standing which reputedly had been moved from the Steiner site. In this way, overa 71 measurements and methods of construction of existing buildings could be observed and recorded before the task of locating and identifying foundations of similar or identical structures was begun. This proved to be a fortuitous decision, as will be seen below.

\section{Site Description}

When the project was begun, the Schob site consisted of a two-story stone house with frame kitchen wing, set in a grassy yard shaded by large anaqua trees and surrounded by a wire fence (Fig. 16). To the southwest stood a number of 19 th century farm buildings, most of which were probably moved from the original farm site when the house was built. Beyond these structures to the south and east were modern metal barns and other later structures not part of the original complex. The task of the archaeological team was to reconstruct the layout of the farm as it was first built in the late 19th century.

\section{Kitchen}

Archaeological work was begun at the site with an attempt to find the location of the 1881-82 kitchen, which some family members say was built separate from the house, as was customary at that time. After the kitchen was damaged by a hurricane in 1886, Mr. Schob moved it over and attached it to the house, where it remains. The family tradition places the first kitchen somewhere directly northeast of its present location, within the fenced yard.

A series of test trenches was laid out over the area (Figs. 17,a and 18,a) and two-inch levels were excavated with trowels, screening ail soil through 1/4inch mesh to obtain maximum recovery of artifacts. In this manner it was hoped to discover any remaining traces of drip lines from the roof, or architectural features such as pier bases or post holes, steps or walks, or a chimney foundation. Artifact distribution could also be plotted to determine possible location of the building through concentrations of small articles and fragments which would have fallen through cracks in the floor of the kitchen.

As work progressed, no architectural features were found, although an area of gravel in Unit $D$ may possibly be faint indications of a drip. Tine. Judging from artifact concentrations alone, it appears that the original site of the kitchen could have been approximately 20 feet to the northeast and more or less 


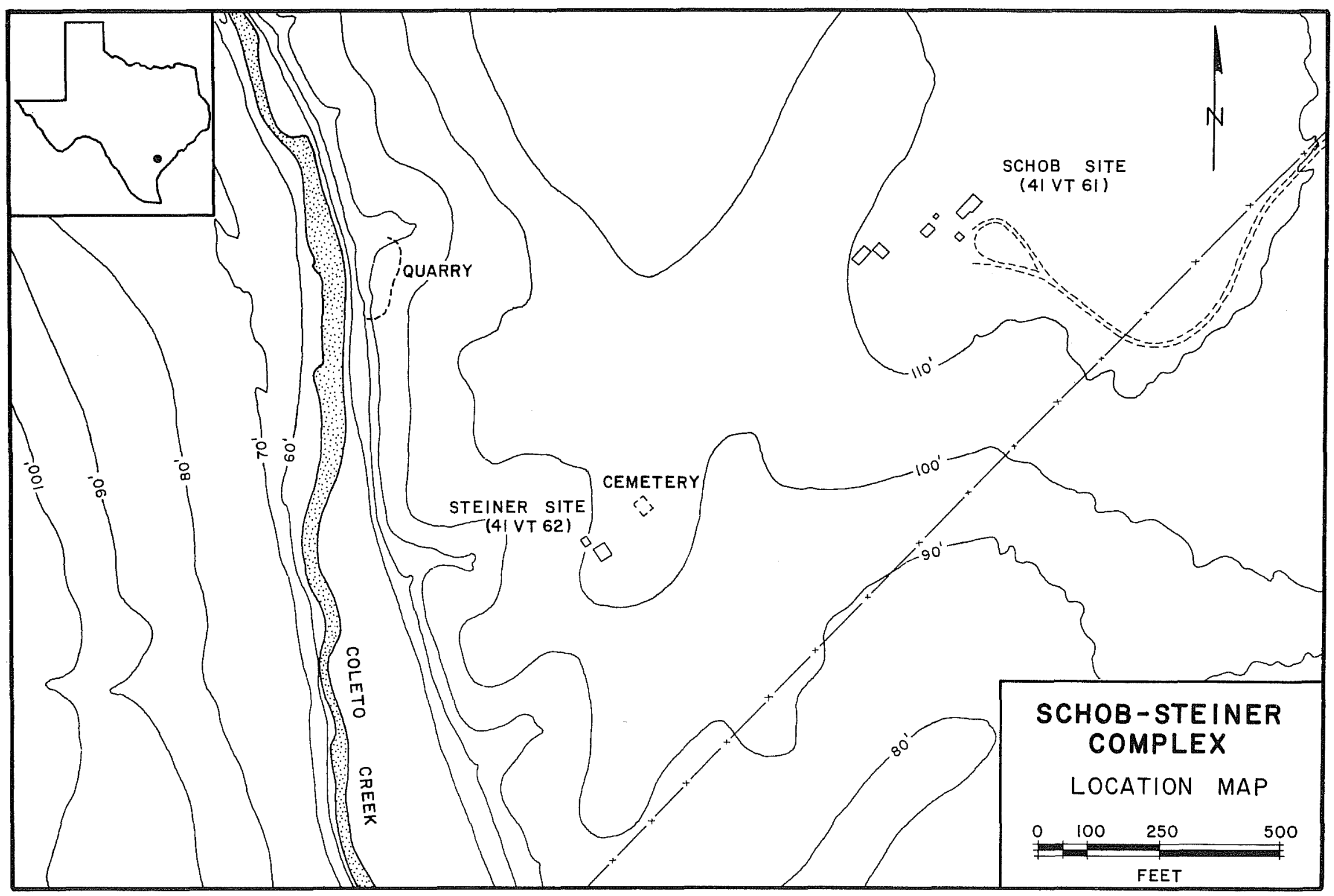

$\cong$

Figure 15. Schob-Steiner Complex Location Map. 


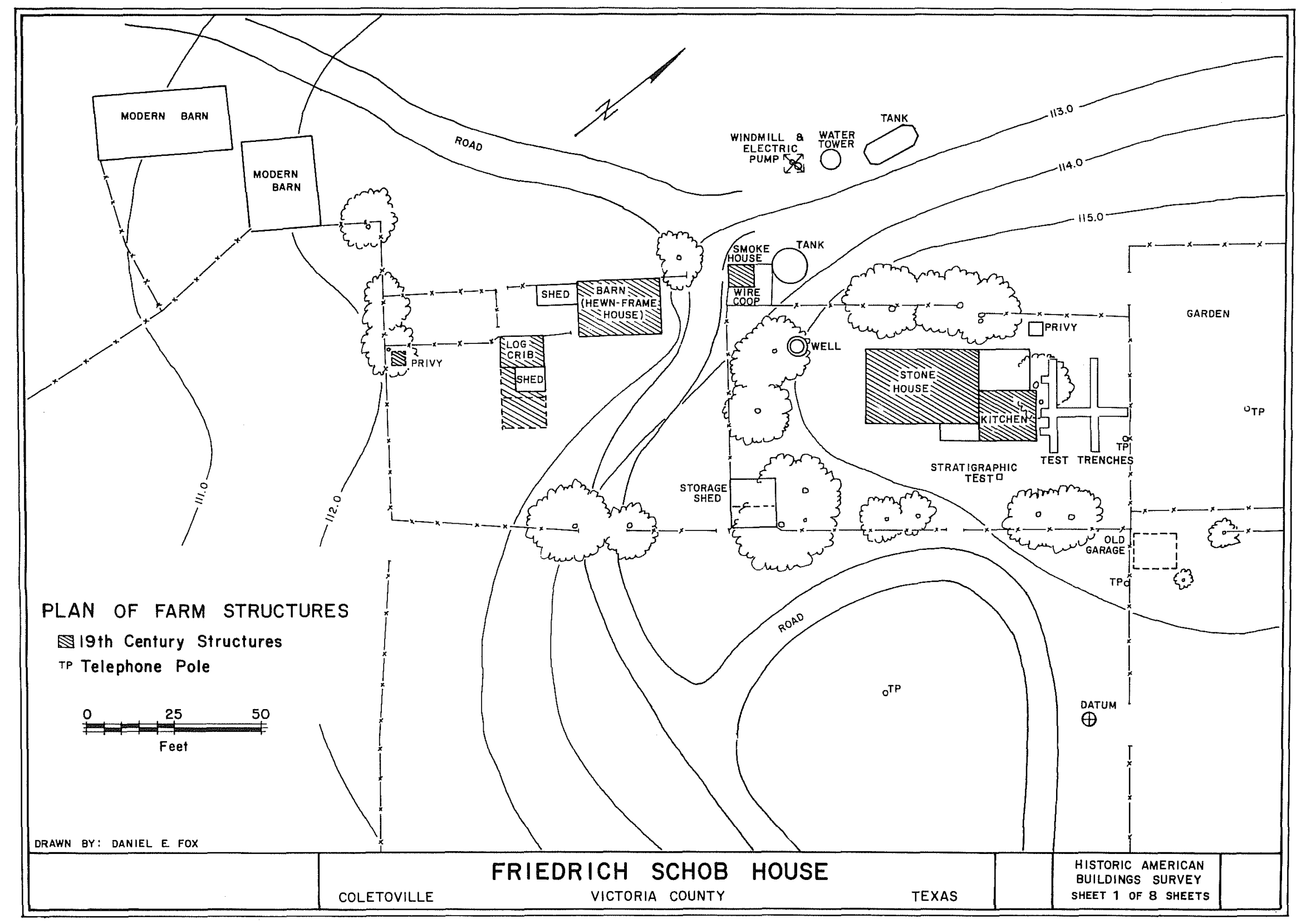

Figure 16. Friedrich Schob House, Plan of Farm Structures. 


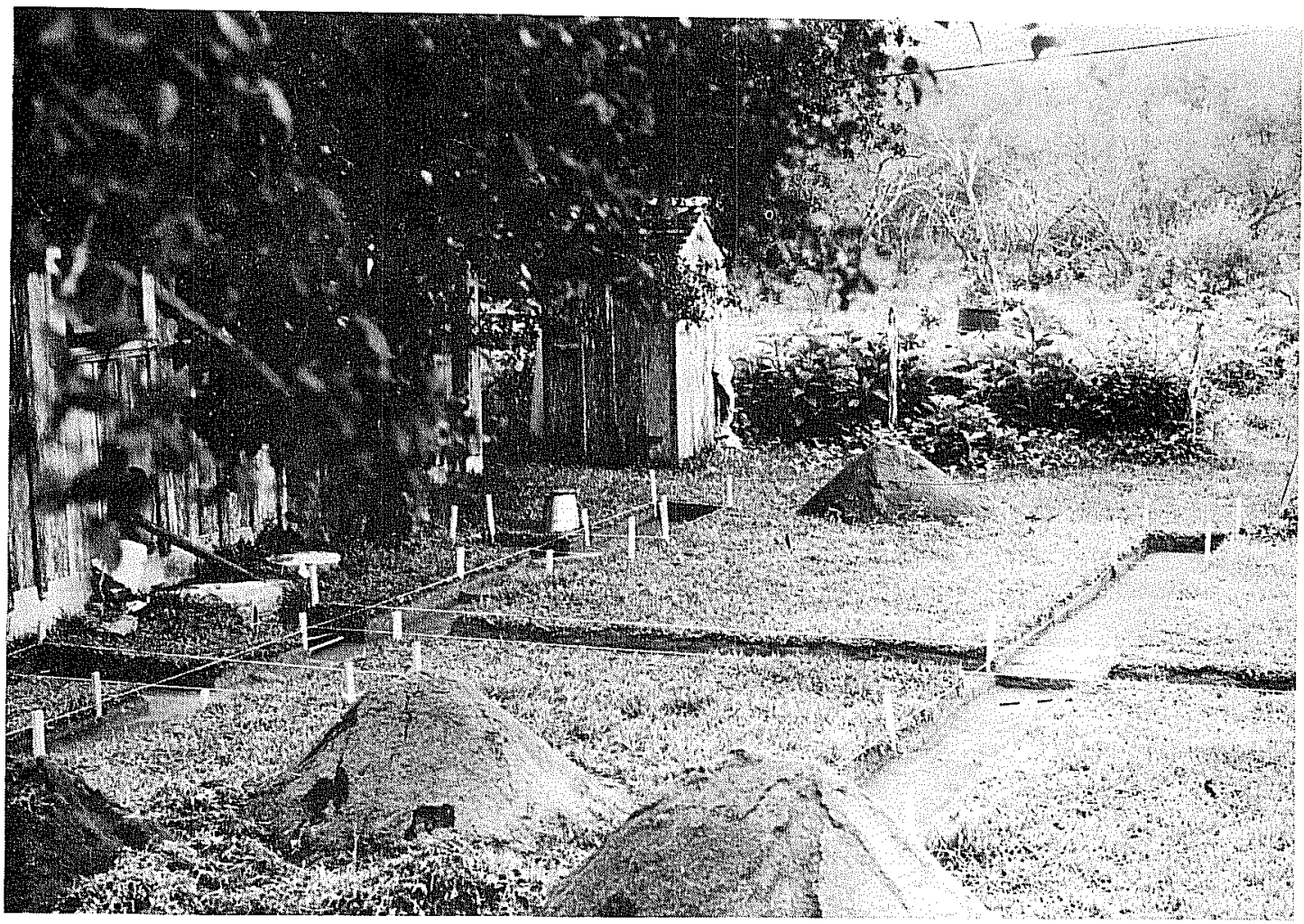

a

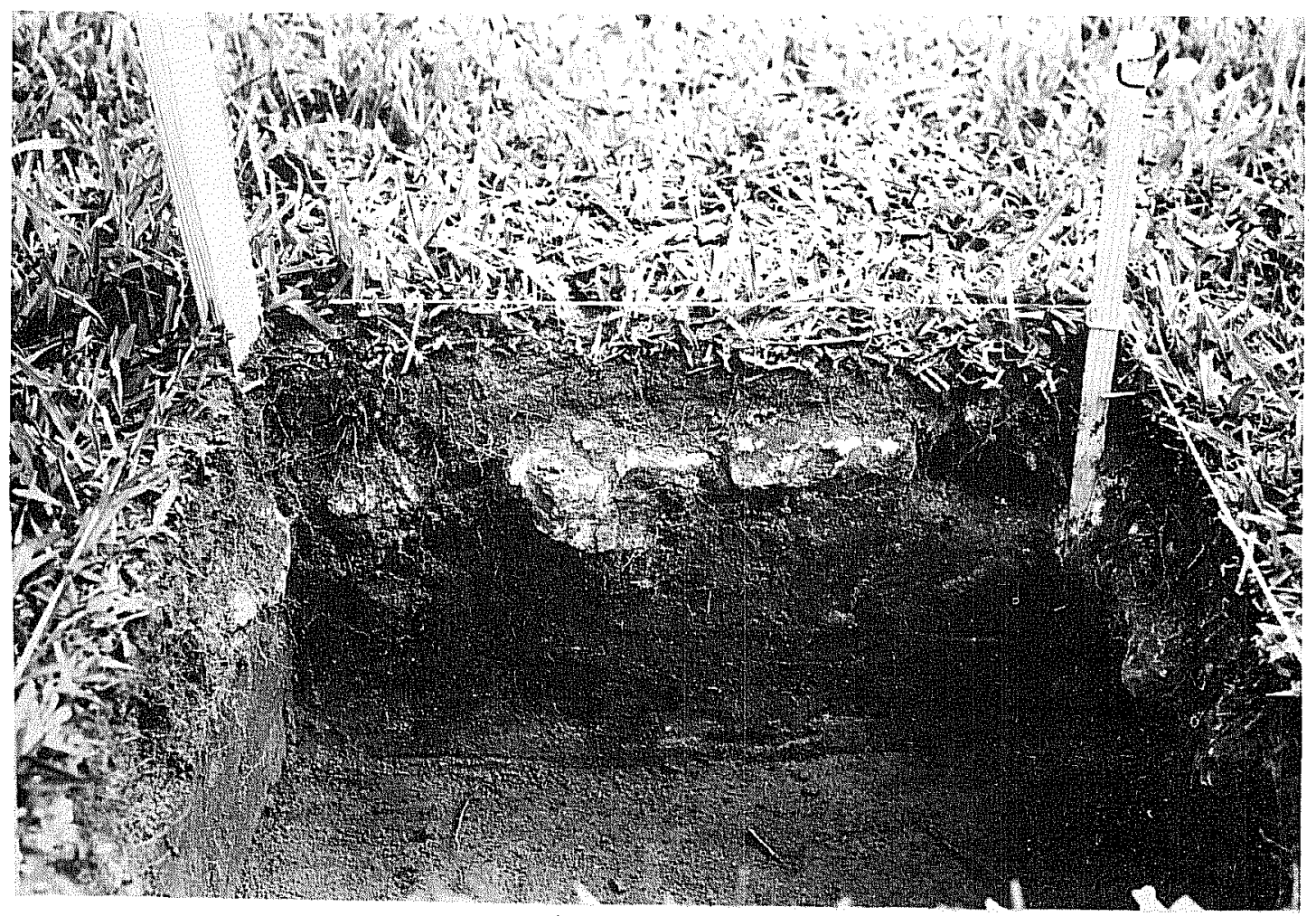

b

Figure 17. Excavations at the Schob House, Photographs. a, test trenches in kitchen area, outhouse-tool shed in background, present kitchen to left; b, stratigraphic test in front yard, showing cobblestone paving beneath the grass. 


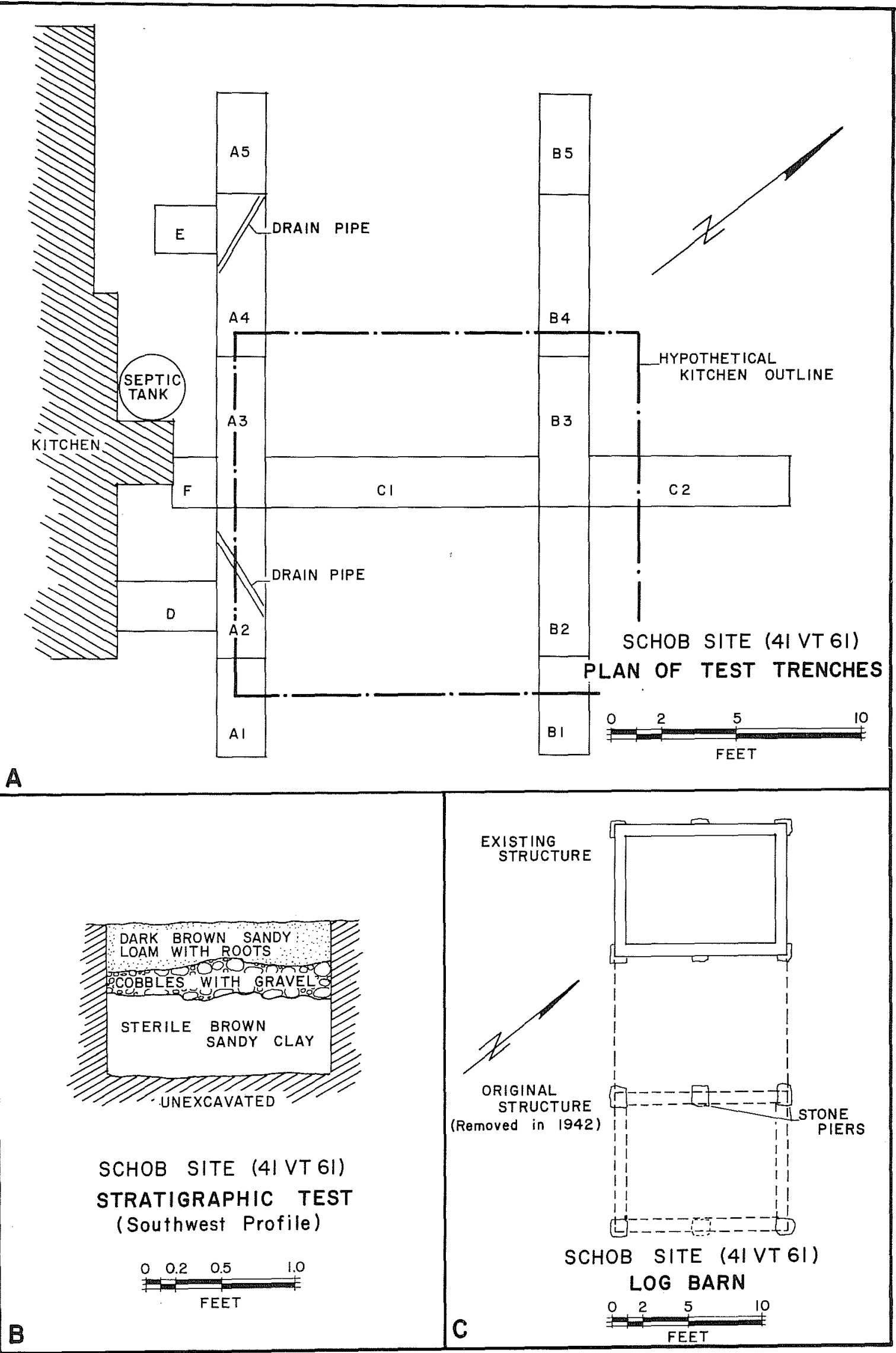

Figure 18. Excavations at the Schob Farm, Drawings. 
in 1 ine with the present kitchen (Fig. 18,a). However, there could be other explanations for the debris in this particular spot, and the location is conjectura 1 .

Taking into consideration the location of the only door to the house, the postulated kitchen site seems feasible, allowing maximum utilization of the kitchen in relation to the house while at the same time avoiding the danger of igniting the house should the kitchen burn. This was not an infrequent problem in the days of wood- or coal-burning stoves and wooden structures, with the only firefighting equipment available being the well and a bucket brigade.

Architectural evidence was probably removed when the structure was moved, and all traces later obscured by cultivation of the tobacco patch which family members recall was next to the kitchen. The only visible disturbances in the area were plastic pipes from the 1968 septic system (Fig. 18,a).

Examination of the beams which support the kitchen revealed that the frame was constructed of reused, hewn members similar to those in the frame of the Steiner house/barn. Evidently the reuse of such timbers was customary practice by German farmers in Texas, as Carter observed the same practice at the Biegel settlement in Fayette County (Carter and Ragsdale 1976:22).

Artifacts recovered (Table 1), with a few notable exceptions, are those one would expect to find on any late 19th century farm site. The fragments are nearly a11 too small to allow identification of individual objects. Plain white earthenware and "ironstone" predominate the ceramics, with fragments of banded and transfer-decorated wares which match patterns present in the collections from the earlier Steiner house. Fragments of fine, white porcelain resemble similar articles handed down in the famiTy. The glass containers represented are also typical, including wine bottles, medicine bottles and canning jars. Buttons and other personal items are the usual 19th century types (Fig. 19).

Construction materials such as window glass and cut and wire nails reflect the stages of construction and remodeling which occurred in the vicinity, and perhaps the destruction of the 1886 hurricane. The original board sheathing of the kitchen was applied with cut nails (Fox, personal observation), but later remodeling efforts used wire nails. Also present were roofing tar and electrical wiring fragments from the 1968 additions.

Perhaps the most interesting artifacts found in the excavations in the kitchen area are a spark coil, terminal and numerous fragments of a battery cell from a Model T Ford automobile (Fig. 20). Such a car was acquired by Amelia Hohman in 1918, at which time a sma11 shed or garage was built just outside the southeast corner of the perimeter fence (Fig. 16).

Cobblestone Pavement

A test excavation just southeast of the present kitchen revealed a layer of cobblestones at four inches below the surface, beneath which the soil was sterile (Figs. 17,b and 18,b). In a subsequent interview, Mrs. Augusta Sandhop recalled that a large portion of the yard around the house had been paved in this manner. (A similar custom can still be observed in the older German settlements in the 


\begin{tabular}{|c|c|c|c|c|c|c|c|c|c|c|c|c|c|c|c|c|c|c|c|c|c|c|c|c|c|c|c|c|c|c|c|c|c|c|c|c|c|c|c|c|c|c|c|c|c|c|c|c|c|}
\hline & & & & & & & & & USER & HOL & $D \quad 1$ & TEM & & & & & & & & & & & ERSONAL & LITEN & & & & & & & DING & MAT & BIAL & & & & & & SCEL & LANEC & & & & & NIMA & LS BO & & & \\
\hline 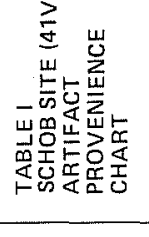 & & & 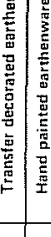 & 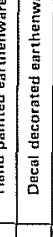 & & & & 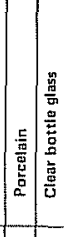 & & & 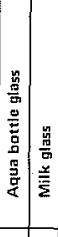 & 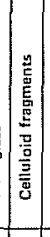 & 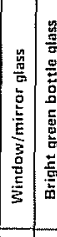 & 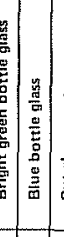 & 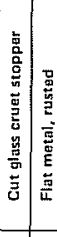 & 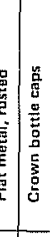 & $\frac{}{\overline{0}}$ & & & & & & 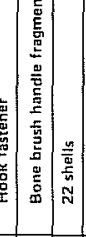 & & & 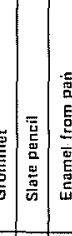 & & & & 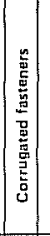 & & & 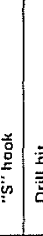 & $\overline{5}$ & 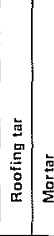 & & & & $\mid$ & & 竞 & & 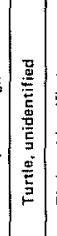 & 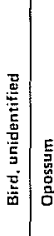 & $\frac{x}{2}$ & 践 & 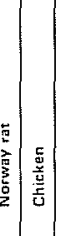 & & ل) \\
\hline A1 to 3 . Level 1 & & & & & & & & & 1 & & & & 1 & & & 3 & & & & & & & & & 1 & & & & & & & & & & 2 & & 5 & & 1 & & & 2 & & & & & 1 & & 320 \\
\hline A1. Level 2 & 5 & & & & & & & 1 & 1 & 1 & 1 & & 41 & & & & 1 & & & & & & & & & & & \begin{tabular}{|l|l|}
6 & 13 \\
\end{tabular} & & & 5 & & & & 7 & 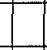 & 4 & & & & & 1 & & & & 1 & 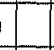 & 12 & 29 .119 \\
\hline A2. Level 2 & 4 & & & 1 & 1 & 5 & & $B$ & \begin{tabular}{|l|l|} 
& 2 \\
\end{tabular} & 2 & 12 & & 114 & & 6 & 1 & & & 1 & 1 & & & 5 & 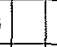 & 2 & & & \begin{tabular}{|l|l|l|}
20 & 26 & 2 \\
26
\end{tabular} & & & 53 & 1 & & & 1 & 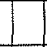 & & & 3 & & & $\mathrm{~g}$ & & & & 7 & 1 & & $477_{275}$ \\
\hline A3 - Lavel 2 & 3 & & & & & 1 & 1 & & 6 & & & & 11 & 1 & 13 & 1 & & 1 & & & & & 3 & 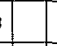 & & & & \begin{tabular}{|l|l|}
8 & 3 \\
\end{tabular} & 2 & & 2 & & 1 & & 1 & T & & & 2 & & 1 & 1 & & & & & 1 & 11 & 1157 \\
\hline A3. Lovel 3 & & & & & & 12 & & 11 & 11 & 1 & & & 6 & & 70 & \begin{tabular}{l|l|}
01 \\
\end{tabular} & & 1 & & & & & 1 & it & & 1 & & \begin{tabular}{|l|l|}
4 & 22 \\
\end{tabular} & 1 & & 21 & & & & & 1 & & & & & & 10 & & & & & 1 & 33 & $399_{123}^{123}$ \\
\hline A4 - Luvel 1 & & & & & & & & 1 & 1 & & & & 2 & & 3 & & & & & & & & 1 & 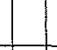 & & & & + & & & ] & & & & 9 & & 6 & & & & & & & & & & & & \begin{tabular}{|l|l}
5 & 27 \\
\end{tabular} \\
\hline Aa - Level 2 & & & 1 & & & & & \begin{tabular}{|l|l|}
1 & 1 \\
\end{tabular} & 1 & & & & & & 20 & & & 1 & & 1 & & & . & & 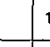 & 1 & 1 & \begin{tabular}{|c|}
12 \\
\end{tabular} & 1 & 2 & 6 & & & & 1 & & 2 & & 2 & & & & & & & & & & $\begin{array}{ll}29 & 91 \\
\end{array}$ \\
\hline A5. Level 1 & & & & & & & & L & 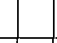 & & & & 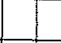 & & 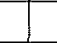 & & & & & & & & 1 & t & 1 & & & 2 & & 1 & 1. & & & & & & & & & & & 1 & & 1 & & & & & \begin{tabular}{l|l}
1 & 9 \\
\end{tabular} \\
\hline A5 - Level 2 & & & & & & & & 3 & \begin{tabular}{l|l|l|} 
& 1 \\
\end{tabular} & 1 & 1 & & 4 & & 2 & & & & & & & & & & & & & \begin{tabular}{|l|l|}
5 & 4 \\
\end{tabular} & & & 21 & & & & & & & & & & & & & 1 & & & & & $2 3 \longdiv { 5 1 }$ \\
\hline B1 to 2-Lovel 7 & & & & & & & & 1 & 1 & & 1 & & 5 & & 7 & 1 & & 1 & & & & 1 & & & & & 1 & \begin{tabular}{|l|l|}
1 & 4 \\
\end{tabular} & & & 5 & & & & & & & & & & & 2 & & 1 & & & & & $\begin{array}{ll}11 & 37 \\
\end{array}$ \\
\hline B1- Lave I 2 & & & & & & & & 3 & 3 & & 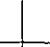 & & 7 & & 9 & 1 & 1 & 2 & 1 & & & & & & & & & \begin{tabular}{|l|l|}
7 & 10 \\
\end{tabular} & & & 4 & & & & & & & \begin{tabular}{l|l}
7 & 2 \\
\end{tabular} & & & & & 1 & & & & & & $23 \quad 75$ \\
\hline 82 - Level 2 & & & & & & & & 1 & 1 & & 1 & & 9 & & 19 & 1 & & & 1 & & & & & & & & & \begin{tabular}{|l|l|}
7 & 8 \\
\end{tabular} & 1 & & 2 & & & & & & & & & & & 2 & & & & & & & 31. \\
\hline B2. Lovel 3 & & & & & & & & 1 & & & & & 2 & & 13 & & & & & 1 & & & 1 & & & & & \begin{tabular}{|l|l|}
6 & 17 \\
\end{tabular} & & & 6 & & & & & & 2 & 2 & & & & 1 & & & & & & & \begin{tabular}{|l|l}
2 & 83 \\
\end{tabular} \\
\hline B3 10 5. Level 1 & & & & & & 4 & & 6 & 6 & & & & 3 & & 17 & & & & & 1 & 1 & & & 1 & & & & \begin{tabular}{|l|l|}
7 & 14 \\
\end{tabular} & 2 & & +1 & & & & & & & & & 2 & & & 1 & & & & & & $41 \quad 100$ \\
\hline в3 - Level 2 & & & & & & & & 4 & 4 & 1 & & & & & 12 & & & 2 & & & & & & & 1 & 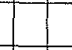 & & \begin{tabular}{|l|l|}
2 & 7 \\
\end{tabular} & & & 2 & & & & & & 5 & 5 & & & & & & & & & & & 1854 \\
\hline B4-Level 2 & & & & & & & & 5 & 5 & & & 2 & & & в & & 1 & 1 & & & & & & & & & & 24 & & & 4 & & & & & & & & & 1 & & & 1 & & & & & & 3057 \\
\hline B5 - Level 2 & & & 1 & & & & & 1 & 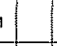 & & 1 & & 1 & & 6 & & & 1 & & 1 & & & & & 1 & & & \begin{tabular}{|l|l|}
1 & 3 \\
\end{tabular} & 1 & & 1 & & & & & & & & & & & & & 1 & & & & & 2948 \\
\hline c1 - Level 1 & & & & & & 1 & & 7 & 7 & 2 & & & 5 & & 8 & & & 3 & & & & & & & & & & 711 & & & 1. & & & & & & & & & & & & & & & & & 210 & $64 \mid 114$ \\
\hline C1 - Leval 2 & 3 & & & & & 1 & & 9 & 1 & 1 & & 1 & 20 & & 41 & & 1 & & 1 & 1 & & & 2 & & & 1 & & \begin{tabular}{|l|l|}
10 & 16 \\
\end{tabular} & & & $\begin{array}{ll}5 & 1 \\
\end{array}$ & & & & & & & & & & & & & & 1 & & 1 & 2 & 41161 \\
\hline C2 - Level 1 & & . & 1 & & & 1 & 1 & 7 & d) & & & & \begin{tabular}{|l|l}
3 & 1 \\
\end{tabular} & & 9 & & & 1 & 4 & 1 & & & 11 & & & 1 & & \begin{tabular}{|l|l|}
5 & 12 \\
\end{tabular} & 1 & & 3 & & & 1 & & & & & & 4 & & & & & & & & & 1165 \\
\hline C2 - Level 2 & & & & & & & & 8 & 3 & & & & 1 & & 32 & & 2 & 1 & 1 & 1 & & & & & & & & \begin{tabular}{|l|l|}
9 & 16 \\
\end{tabular} & 1 & & 9 & & & & & & 2 & & & & & & 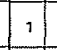 & 2 & & & & 16 & $60 \quad 247$ \\
\hline D- Level 1 & 1 & & & & & & & 2 & 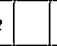 & & & & 2 & & 18 & & & 1 & & & & & & & & & & 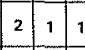 & & & 19 & & & & & & & & & 2 & & & & & & & & & 40 \\
\hline D- Levol 2 & & & & & & & 1 & 11 & 1 & 1 & & & 19 & & 20 & 1 & & & & & & & 2 & & & & & \begin{tabular}{|l|l|}
6 & 6 \\
\end{tabular} & & & 14 & & & & & & & & & & & 9 & & & & & 1 & & $\begin{array}{ll}16 & 98 \\
\end{array}$ \\
\hline E- Level 1 & & & & & & & & & & & & & & & 2 & 1 & & & & & & & & & & & & 1 & & & 7 & & & & & & 1 & & & & & & & & & & 1 & & 29) 35 \\
\hline E. Level 2 & & & & & & 1 & & 2 & 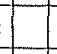 & & & & 3 & & & 1 & & & & & & & & & & & & \begin{tabular}{|l|l|}
1 & 5 \\
\end{tabular} & & & 2 & & & 1 & & & & & & & & 2 & & & & & & & 18 \\
\hline F. Lavel 2 & & & 1 & & & & & & 1 & & & & 1 & & & & & & & & & & & & & & & \begin{tabular}{|l|l|}
3 & 1 \\
\end{tabular} & & & & & & & & & & & & & & 2 & & & & & & & $\begin{array}{lll}7 & 16 \\
\end{array}$ \\
\hline F- Level 3 & 1 & & & & & & & 2 & 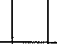 & & & & 1 & & & & & & & & & & & & & & & & & & & & & & & & & & & & & & & & & & & & 4 \\
\hline F. Leval 4 & & & & & & & & 1 & 1 & & & & & & 2 & & 1 & & & & & & & & & & & 2 & & & & & & & & & & & & & & & & & & & & & \\
\hline & 19 & & & & & & & & 7. 9 & & & & & & & & & & & & & & & & & & & & & & & & & & & & & & & & & & & & & & & & 300] \\
\hline
\end{tabular}



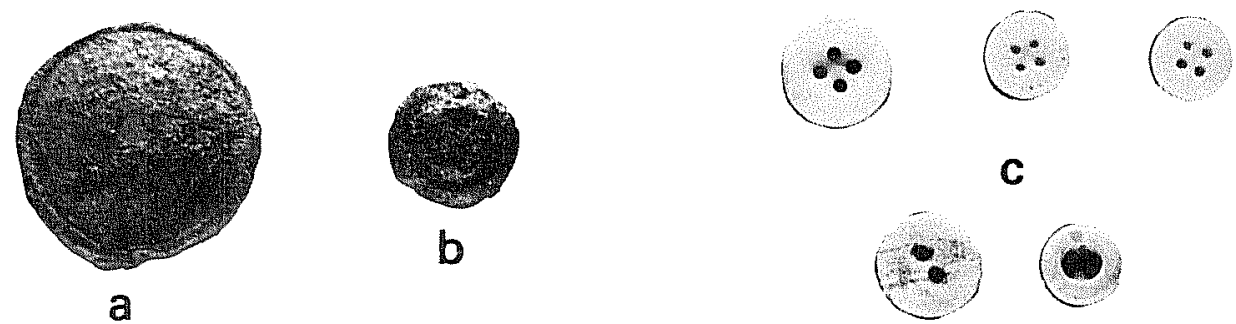

c

a
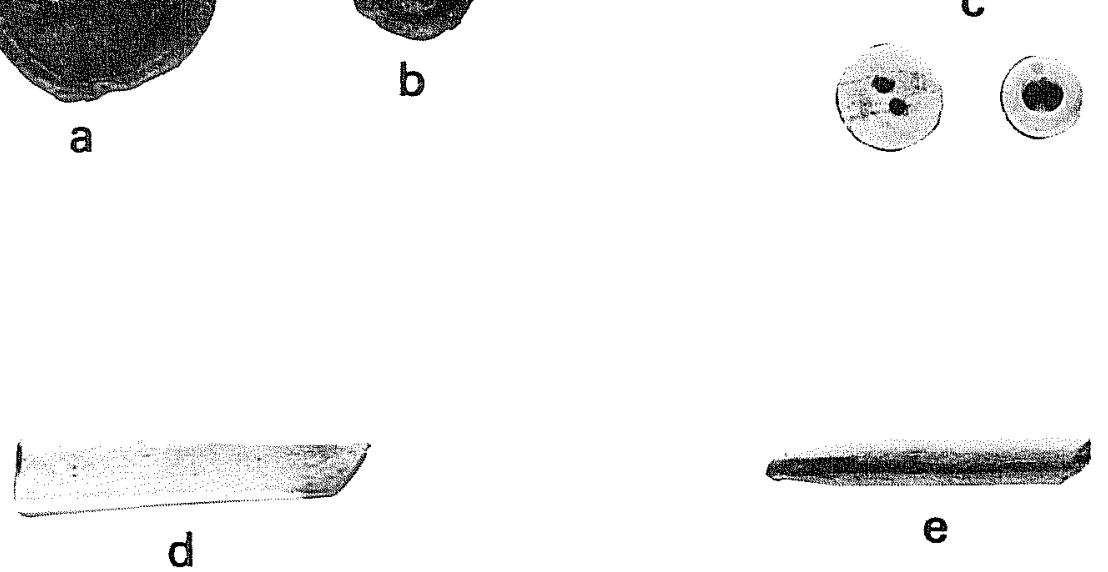

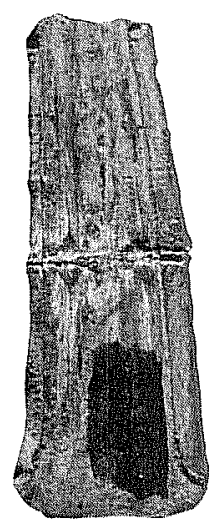

g
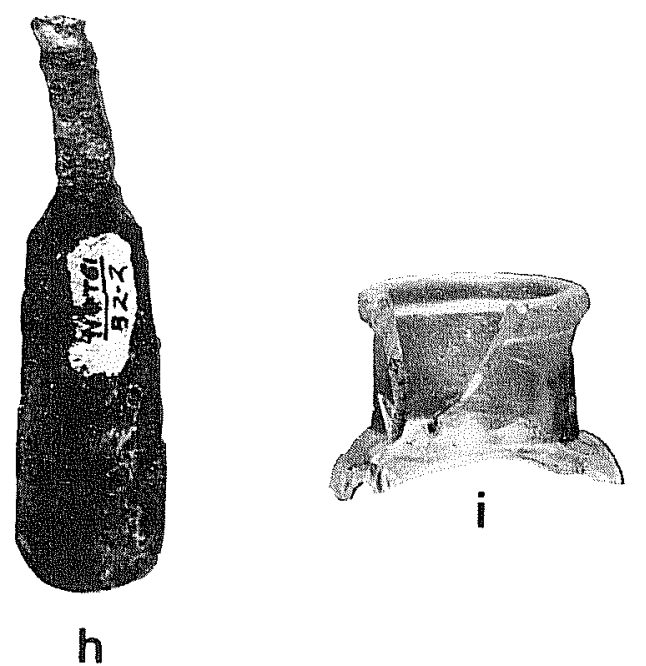

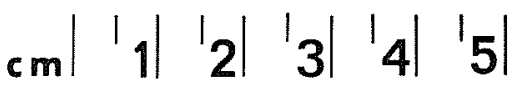

Figure 19. Artifacts from Schob Kitchen. a, compound metal button; $b$, metal gripper; c, glass and shell buttons; $d$, brush handle incised "France"; e, slate pencil; $f$, jar lid liner; $g$, spoon handle; $h$, spoon handle; $i$, bottle neck, hand tooled; $j$, glass stopper. 


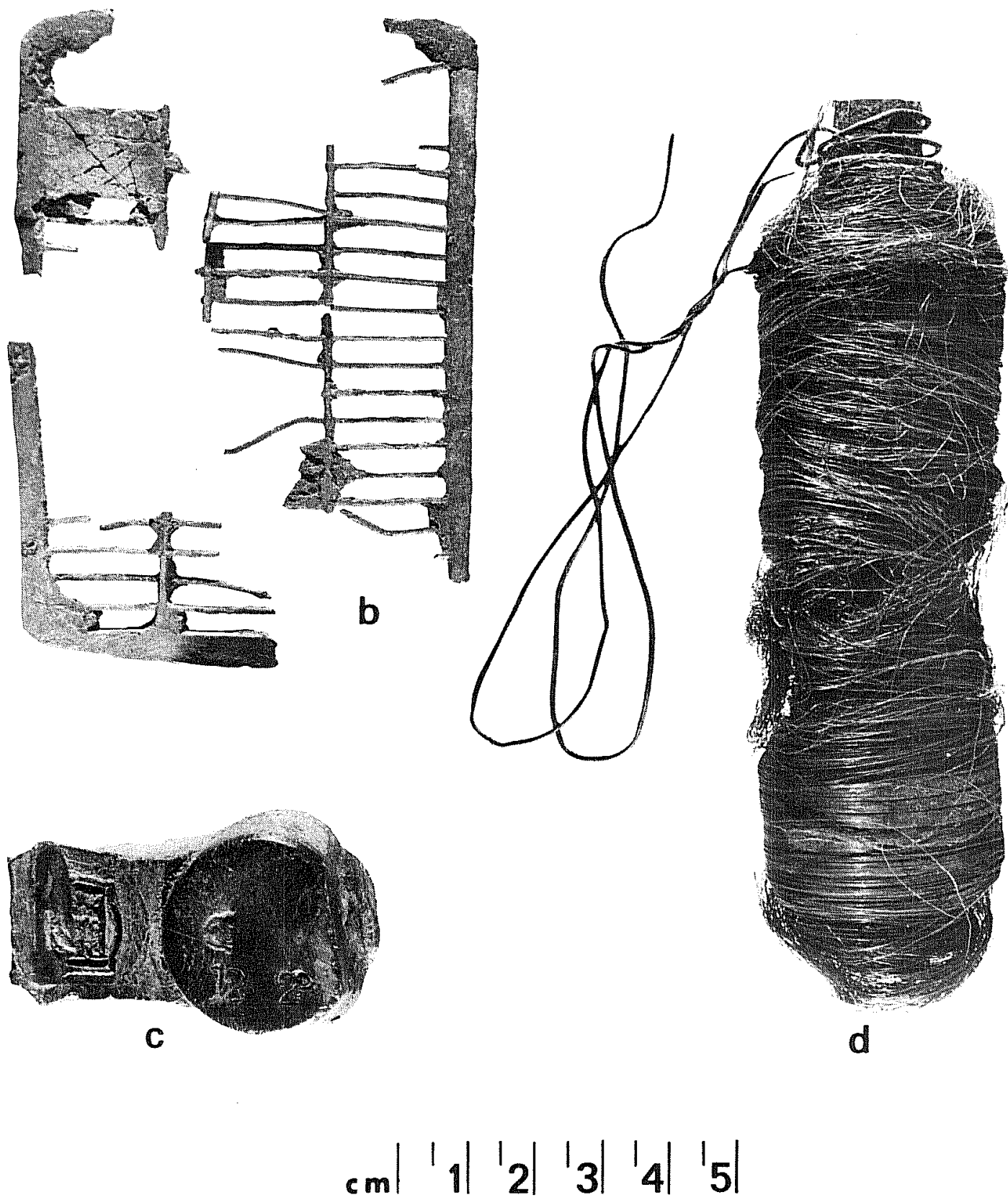

Figure 20. Metal Artifacts from Schob Kitchen. a, unidentified metal object; b, battery fragments; c, battery cap; d, spark coil. 
Texas Hil1 Country. An area around the house is kept entirely free of grass or weeds and, in some instances, is paved with gravel.) Probing with a steel rod revealed that the pavement extended around the stone house, varying in width from 17 feet across the front to 8 feet across the back. The pavement stopped abruptly at a point one foot east of the line of the present east wall of the kitchen; what this might imply about the first location of the kitchen is hard to say. It probably delineates the tobacco patch which was once located next to the kitchen.

We11

The original well to the west of the house is presently 58 feet deep. The lining is sandstone, cut in wedge-shaped blocks to form the curve of the circular structure, which has an inner diameter of three feet and an outside diameter of five feet. No indication remains of the superstructure remembered by Mrs. Sandhop.

Privy

A small structure near the north corner of the stone house is reputed to be the original outhouse or privy, which, according to the memories of Mrs. Augusta Sandhop, was located behind the log barn (see Fig. 16). Apparently the structure was moved to its present location during the remodeling in 1968 and converted into a tool shed and wash house.

Hewn Frame Barn

Due to the detailed study being done by the architect, archaeological efforts on this structure were limited to measurement of overall dimensions and general observations on possible room orientation and use, for reference in determining its placement on the foundations at the Steiner site.

\section{$\underline{\text { Log Barn }}$}

As it presently stands, this barn consists of a log crib approximately $8 \times 12 \mathrm{ft}$ with a wooden shed attached to the southeast side. Family tradition holds that this is the remaining portion of a double-crib barn with dog run in the center which was partially destroyed by a hurricane in 1942. It is also said to have been moved from the original Steiner farmstead (Mrs. Johns, personal communication).

The construction of the barn of hewn logs with half-dovetail corner notching bears witness to its mid-19th century origin (Jordan 1972:59-76). Identica1 construction has been found on other early German sites in Texas, such as the Legler and Polasek sites in Fayette County (Carter and Ragsdale 1976:33-34, 37). It seems likely that this was one of the first buildings on the Steiner place and was, indeed, moved to $i$ ts present site at a later date.

Probing of the area to the southeast of the remaining crib revealed the presence of stone pier bases similar to the ones supporting the remaining crib. Minimal 
excavation exposed a pattern of piers at the corners and mid-points of the 12-foot walls (Figs. 18, c and 21), confirming the original double-crib construction. Unfortunately time did not allow a search for the first location of the $\log$ barn at the Steiner site.

Smokehouse/Guinea House

A small structure made of vertical logs at the west corner of the yard is reputed to be the old smokehouse, brought up from the Steiner site. The building measures 7 feet 6 inches $\times 6$ feet 6 inches, and its construction appears to date to the mid-19th century. Careful probing in the earthen floor revealed no firebox or other features often associated with smokehouse utilization (Noel Hume 1969:139; Sloane 1967:84), and no charcoal or other physical signs of burning were present.

\section{Observations}

Judging from family traditions, archaeological investigations and observations of other German farm sites in Texas, it appears that the following sequence of events occurred at the Schob site.

In 1880 Friedrich Schob began to construct a new home, hauling large sandstone blocks up from the creek bank quarry one at a time on his horse-drawn wagon and dressing them on the site (Ed Berger, personal communication). The house was patterned after one he knew in Germany (Mrs. Geraldine Johns, personal communication). He worked slowly and meticulously, as was his custom, taking two years to complete construction. A frame kitchen was built separate from the house; food was prepared and the family often ate their meals in this kitchen.

Once the house was completed, those structures at the old site which were still in good condition were moved up to become the outbuildings for the new farmstead. These included the original house frame (which with new siding and doors became a barn), the old log barn and the smokehouse. Other than necessary relocation of the kitchen in 1886 and construction of a few auxiliary sheds, the layout of the Schob farmstead probably remained essentially the same until the death of the Schobs in the 1920s.

\section{THE STEINER SITE}

The archaeological crew then moved to the Steiner homestead (Fig. 22). When work began, the site was completely overgrown by trees, underbrush and grapevines. As clearing progressed, it became evident that there were other structures in the immediate area in addition to the house and well. A low mound to the northwest of the cellar hole (Fig. 22, Structure 2) contained fragments of cut stone which appeared to be still in place. Also, a small clearing about 50 feet to the west of the house contained a patterned arrangement of stone set solidly into the ground (Fig. 22, structure 3 ). 


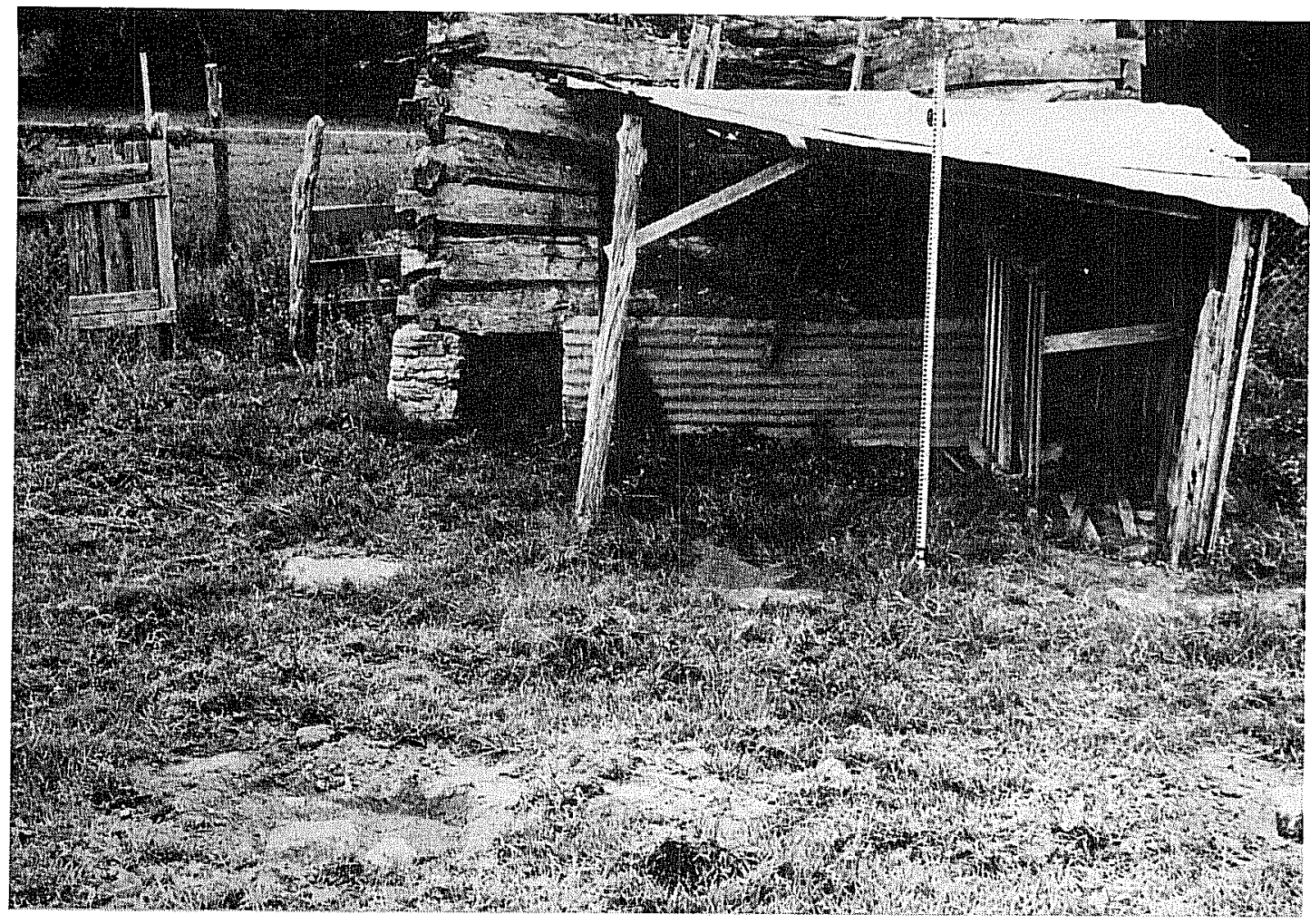

a

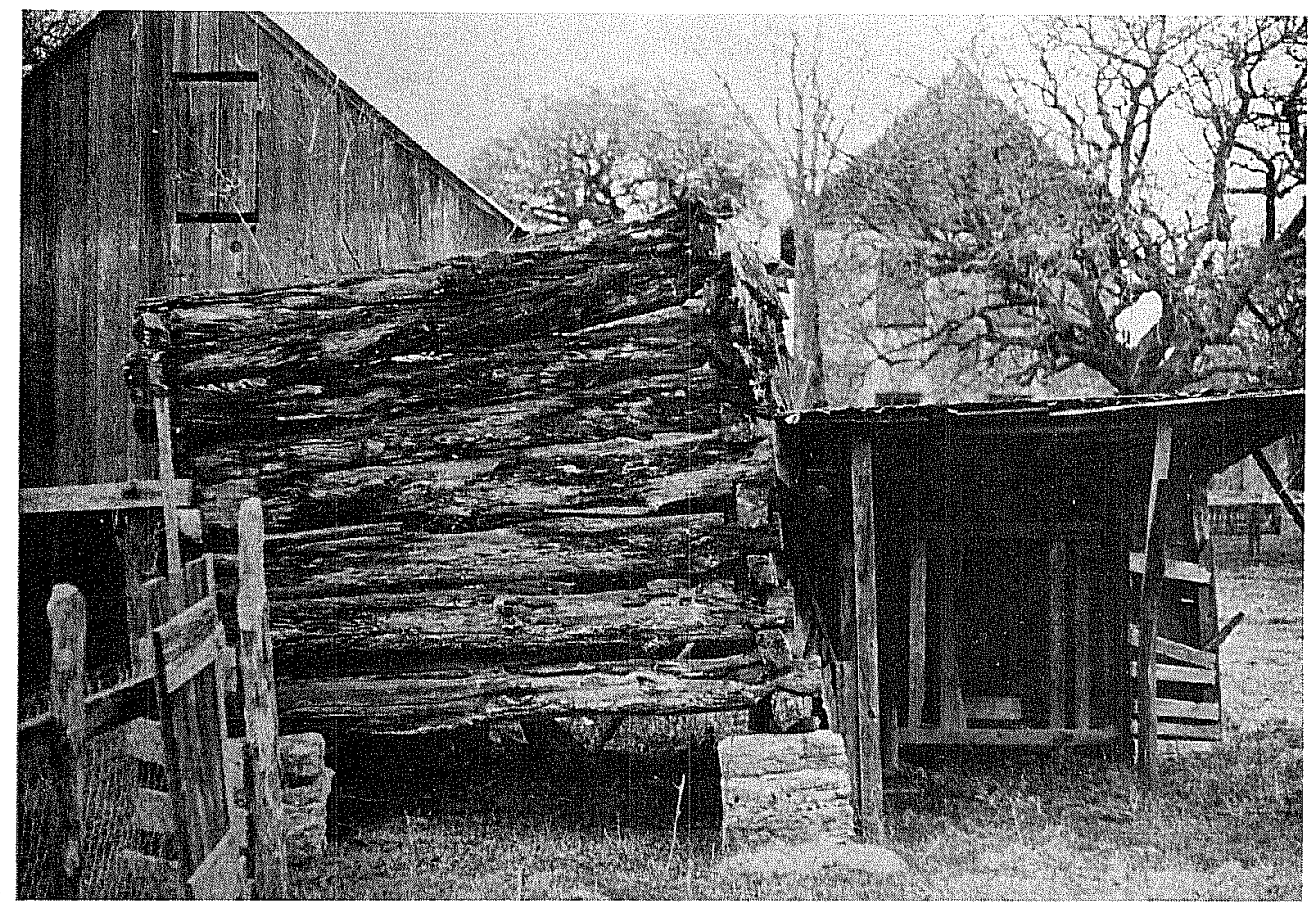

b

Figure 21. Log Shed at Schob Farm. a, shed from southeast, showing locations of stone piers for the missing section in foreground; $b$, shed from southwest, note half-dovetail notching. Barn made from Steiner house to the left. Schob house in the background. 


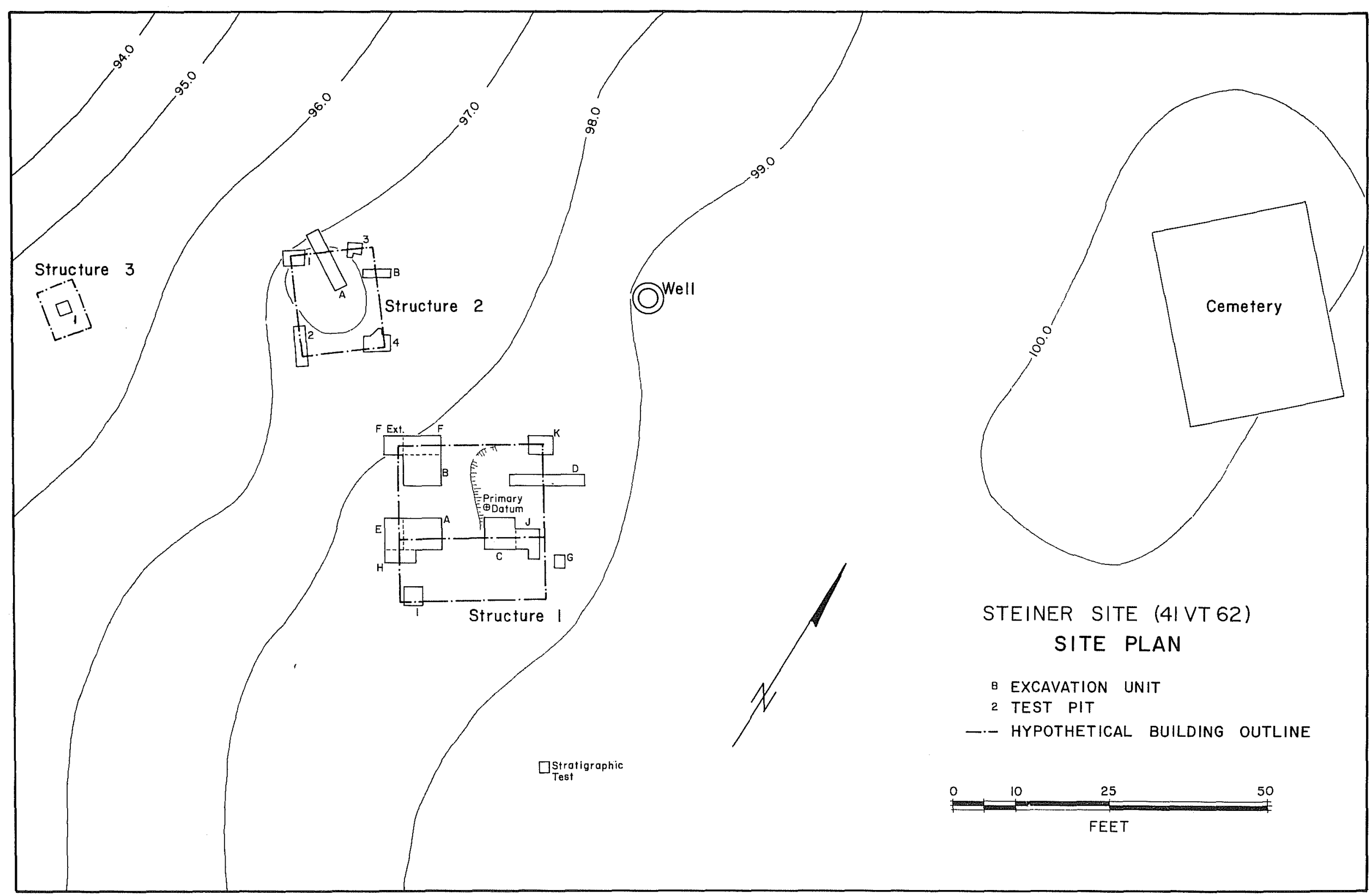

Figure 22. Steiner Site (41 VT 62), Site Plan. 
Structure 1- House

The general house layout was more easily seen after the underbrush was removed. The cellar hole was an irregular depression on the east side, and traces of foundation walls showed here and there above the ground surface to the west. It was immediately apparent that the house originally had a porch across the southeast side, a detail not unusual on early Texas farmhouses (Alexander 1966:14; Roemer 1935:55).

The first problem in beginning excavations was to determine the precise orientation of the walls of the collapsed cellar in order not to waste time in exploratory excavations. To accomplish this, the crew worked with trowels to clear the cellar surface of debris and loose rocks, making a controlled artifact collection and continual observations of the wall lines as they appeared. Within a short time, the line of the southwest cellar wall began to emerge (Fig. 23,a).

At this point, a datum was created by driving a large nail into a tree in the center of the site, which was arbitrarily designated the $100 \mathrm{ft}$ elevation. A grid was then laid out over the house foundations, including the cellar hole and a low mound to the southwest over which the house appeared to extend (Fig. 23,b). Since time was limited and the inmediate problem was to locate foundation walls to determine the orientation and layout of the original house, the grid lines were laid out so as to yield a maximum amount of structural information with a minimum amount of excavation. A two-foot-square stratigraphic test was excavated just southeast of the house area to a depth of three feet in order to determine the natural soil conditions at the site.

A controlled surface collection was made from the entire gridded area. Units $A$ and $B$ were then excavated with trowels through tan, sandy clay loam to a depth of 24 inches below datum, revealing the inner edges of the stone house foundation. In Unit $A$, approximately 20 inches below datum, a dark brown Tayer appeared (Fig. 24), above which were found mid-19th century artifacts. This dark stratum contained chert flakes and cores indicating the presence of a prehistoric site in the area long before the house was built. This same deposit occurred in all excavation units at the site, except for the cellar hole and stratigraphic test. An additional 15-inch-square test to 30 inches in the northeast corner of Unit $A$ revealed sterile red clay at 24 inches and indicated that the prehistoric deposit averaged 6 inches in thickness.

After the inner line of the west wall was located in Units $A$ and $B$, additional units (see Fig. 25) were troweled to approximately 27 inches to determine the width and method of construction of the foundation. The wall averaged two feet in width and was constructed of two parallel rows of rough sandstone filled in the center with rubble and caliche. It appeared to sit on, and slightly into, the dark brown layer, with no footings below. No traces of piers or posts were found, and the wal1 appeared to run continuously across the north and west wal1s and across the front of the porch. There was no indication of a wall across the front of the house where the porch joined the structure (Unit A). Unit I was excavated to reveal the location of the corner of the porch foundation.

On the eastern portion of the house, careful observation suggested that the rock fall in the center of the east wall of the cellar hole was more than just a collapsed section of the cellar wall. Unit D, excavated across this area, 


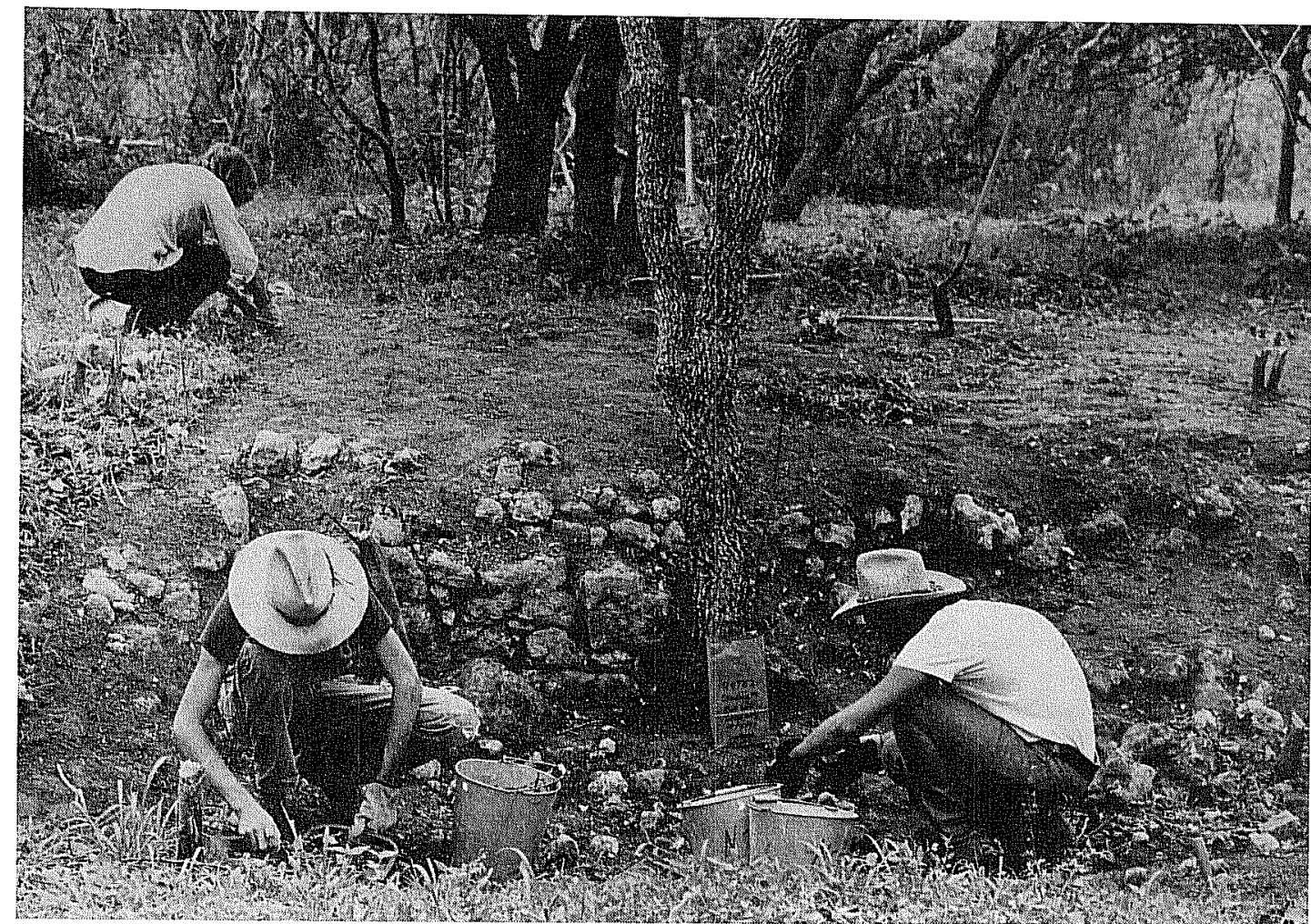

a

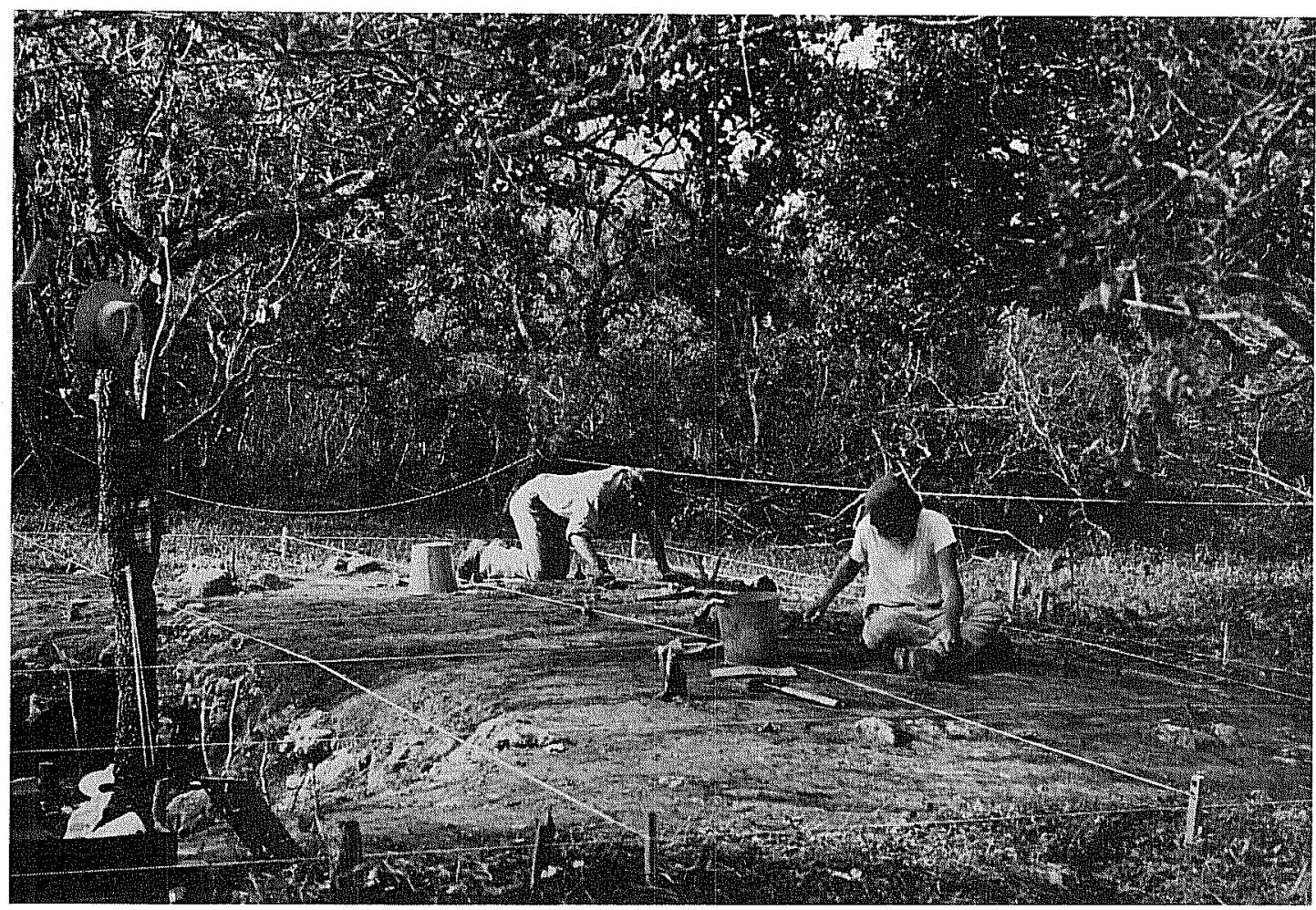

b

Figure 23. Excavations at Steiner House, Structure 1. a, cleaning the surface in preparation for laying out the grid. Cellar depression is in the foreground; $b$, start of excavation within grid units. 


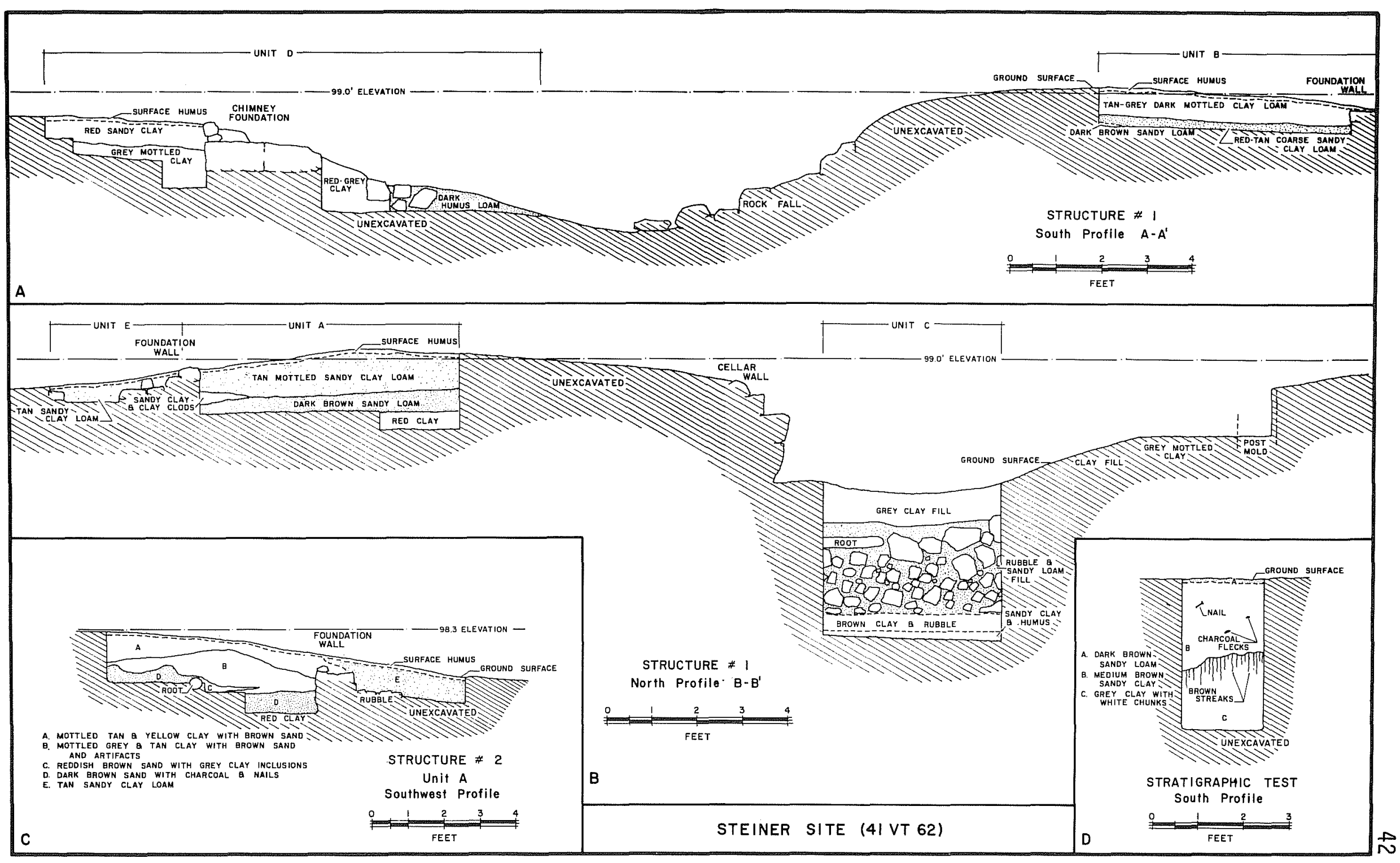

Figure 24. Steiner Site (41 VT 62), Excavation Profiles. 


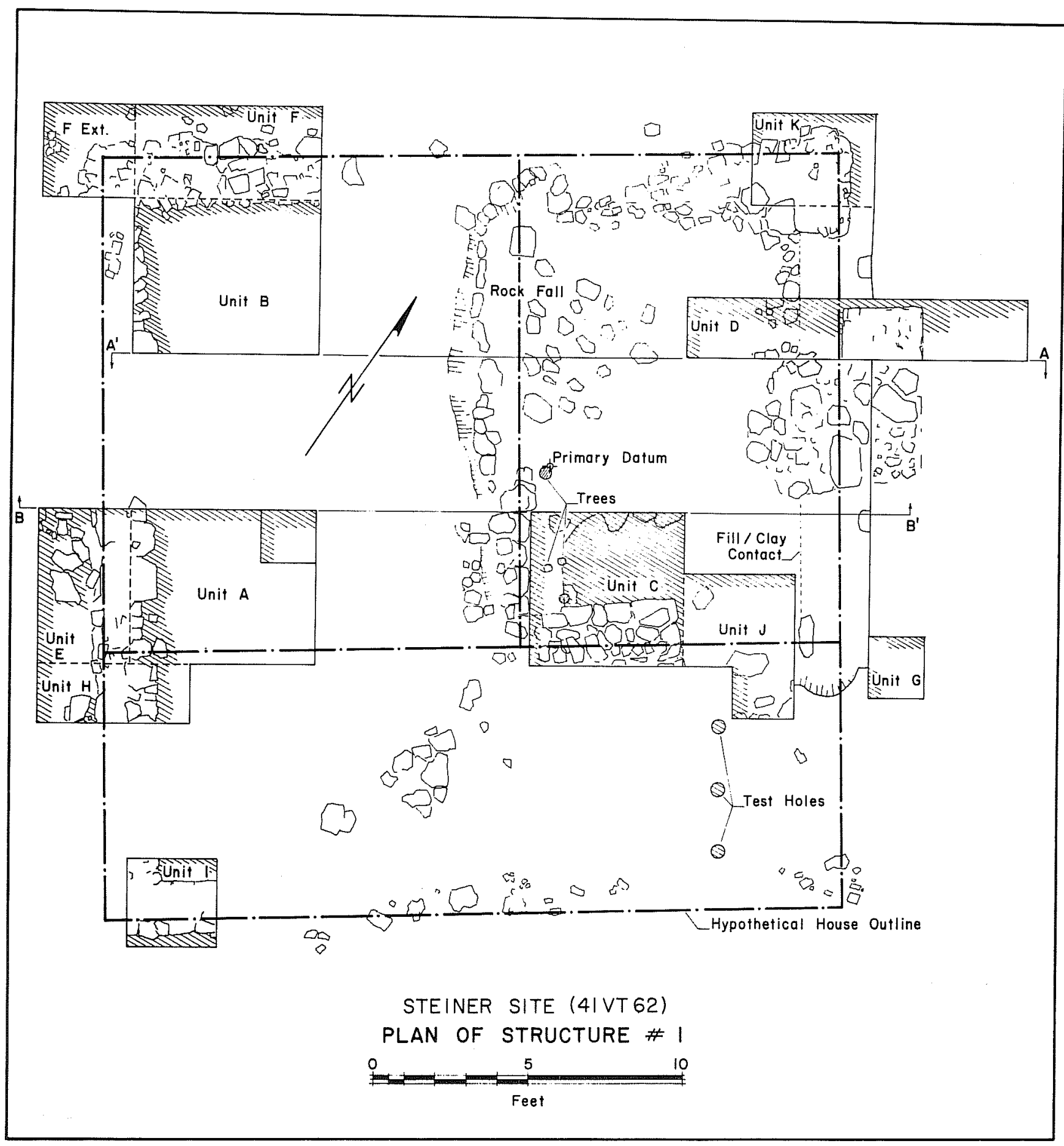

Figure 25. Steiner site (41 VT 62), Plan of Structure 1. 
revealed the base of a chimney made of cut sandstone blocks set into the basal clay just outside the line of the basement excavation (Figs. 24,a and 25). The bottom of the chimney foundation was 40 inches below datum.

No stone lining for the east wall of the cellar hole was found in this excavation unit, but the edge of the hole dug for the cellar was plainly visible in the profile (Fig. 24,a). The same situation was found to the south of the chimney when the surface was cleared. Two post holes were located, one on either side of the chimney base. These were probably from scaffolding used in construction of the chimney. It appears that the east wall of the cellar was not stone-lined.

In order to determine the depth and sample the fill of the cellar, Unit $C$ was excavated to the cellar floor at ca. 84 inches below datum (Fig. 26,a). The uppermost 10 inches, as might be expected, was composed of washed-in gray clay with a few late-19th century artifacts. The rubble fill below this appeared to consist of wall fall, chimney fall and broken bottles and other artifacts which were discarded after the site was abandoned. The bottom six inches was primarily dark brown sandy clay which would have accumulated both at the time the house was being moved and from that time until the walls began to slump. It contained fragments of broken wine bottles and sherds of a stoneware jug and preserve jar such as would have been stored in the cellar. The hardware fragments could also have come from objects stored or used in the cellar. The presence of a German coin dated 1844 near the bottom of this deposit suggests that at least a part of the bottom level was accumulated while the cellar was still in use.

The south wall of the cellar hole presented some unresolved questions at this point. There was a noticeable depression in this wall which could mean a stairway for access to the cellar. However, this did not seem likely since it would have run under the front porch. Also, family tradition holds that cellar access was through a trap door from the room above. Unit $\mathrm{J}$ was excavated into this area and revealed no sign of steps nor of structures to support them. Three test holes dug with a post hole auger to the south within the depression revealed clay immediately below the top soil, except in the northernmost hole which evidently caught the edge of the cellar hole excavation. Unfortunately, at this point a heavy rain filled the cellar excavations with water, preventing further investigation of the area within the time allotted.

It appears that the south wall of the cellar may have been deliberately pulled down or sloped into the cellar. It was not determined whether this was part of the original scheme, or whether it was done after the site was abandoned, perhaps to allow livestock to climb out of the hole.

Structure 2 - Kitchen

An area to the northwest of Structure 1 was designated Structure 2. When first cleared, this feature consisted of a low mound of earth (Fig. 27,a) in the surface of which were several groups of shaped sandstone blocks that appeared to be wall foundations. A trench designated Unit A (Fig. 28) was excavated into the center of the mound in hopes of locating a wall line and determining the content of the mound. After the surface humus was removed, a sterile yellow/tan clay deposit was encountered. Below this clay cap was a darker deposit of gray and tan clay containing numerous artifacts and animal bones. Near the north end of 


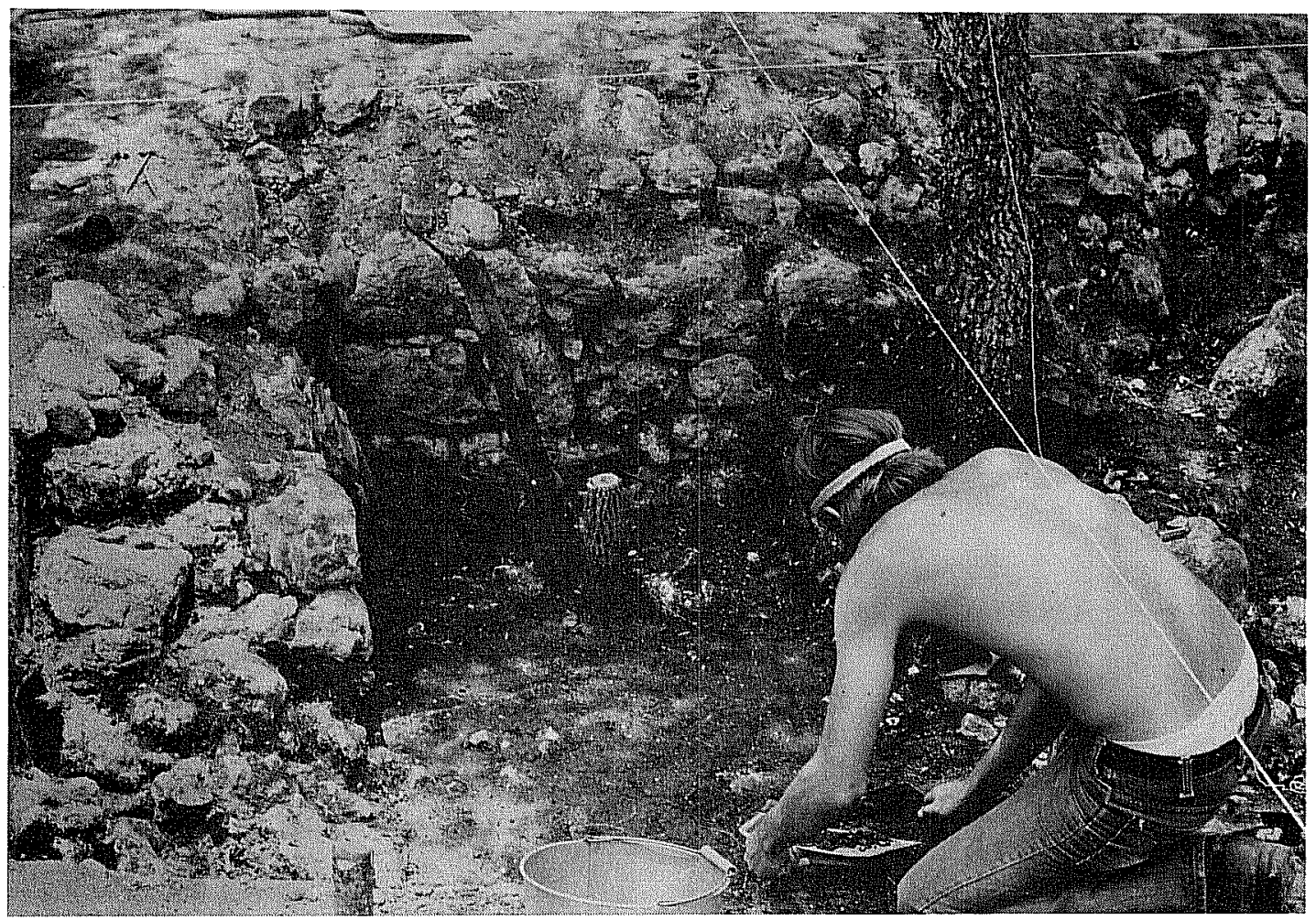

a

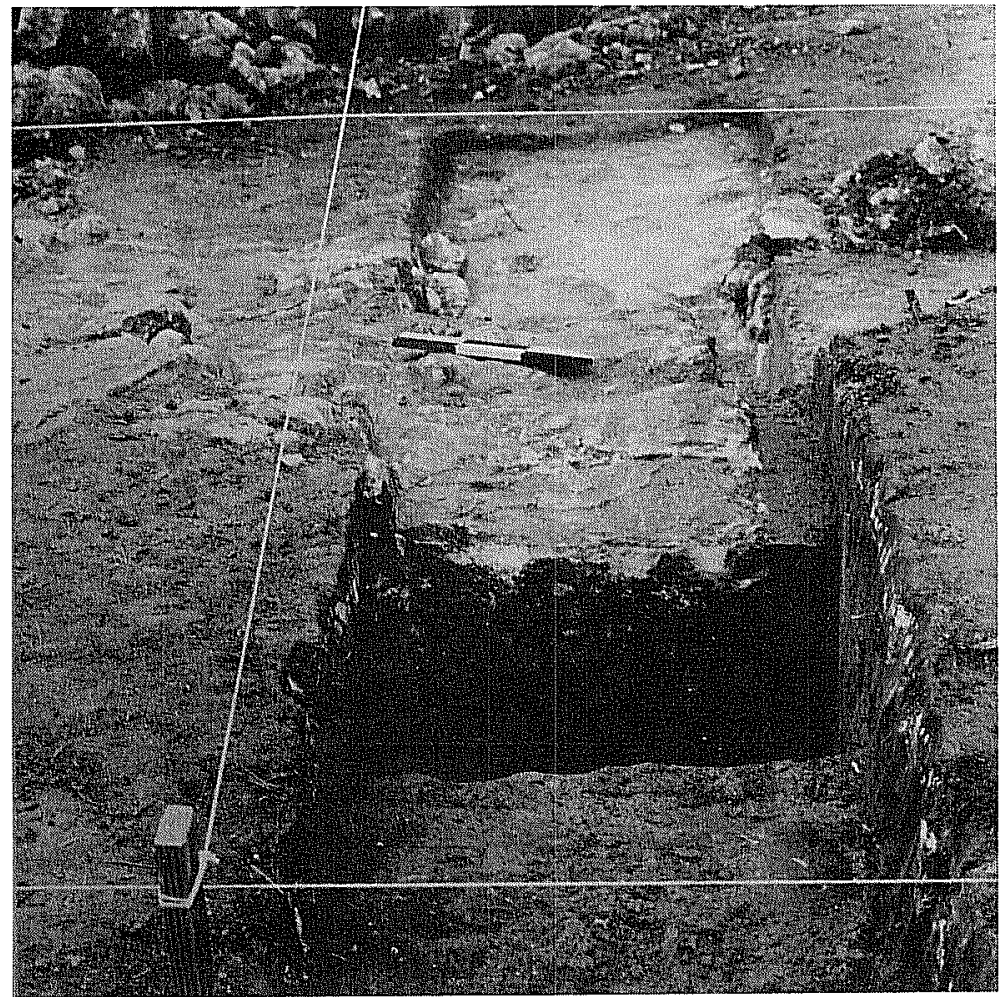

b

Figure 26. Excavations at Steiner House, Structure 1. a, Unit $C$ in corner of cellar; $b$, Unit $D$ from northeast, showing depth of chimney footing. 


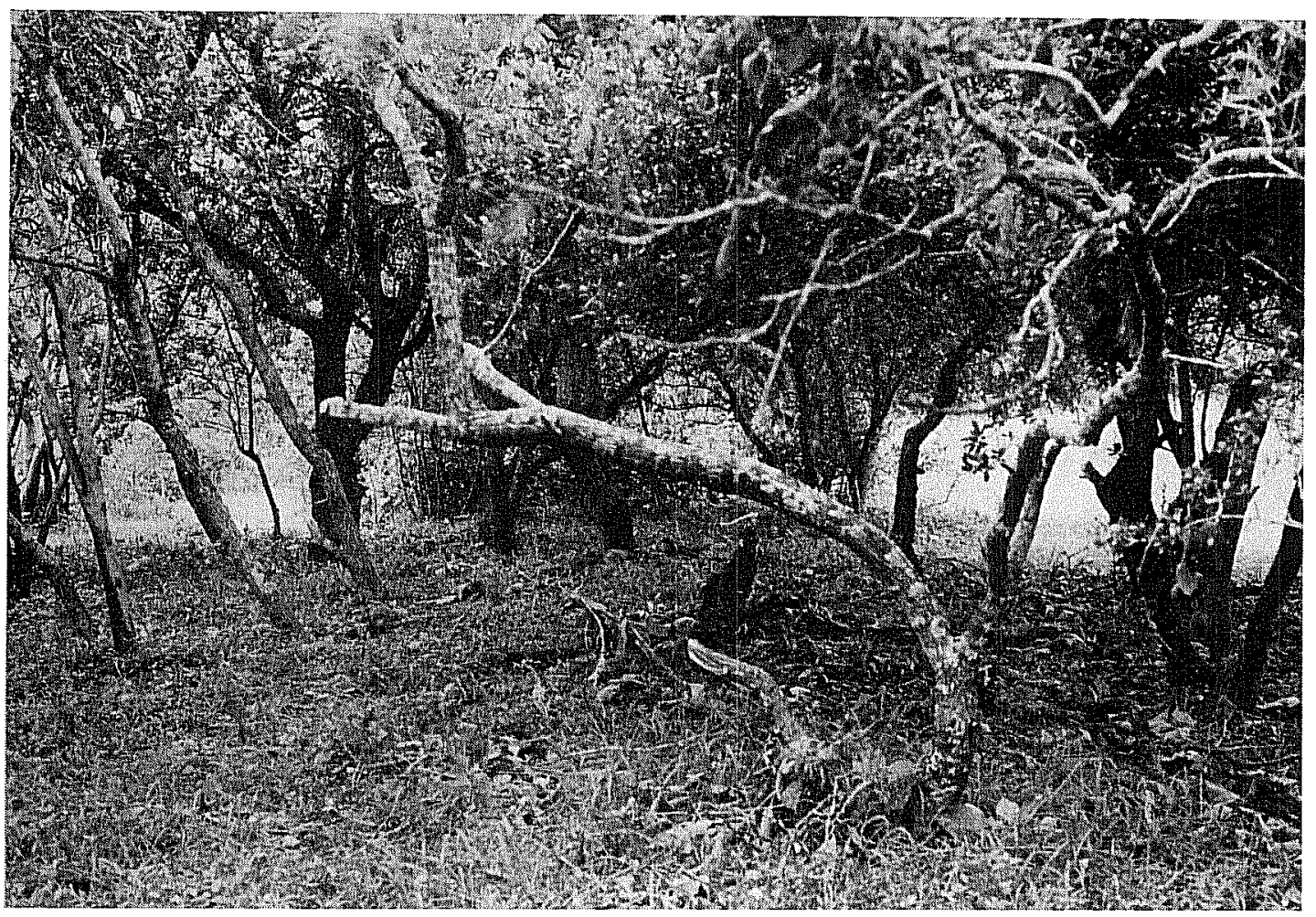

a

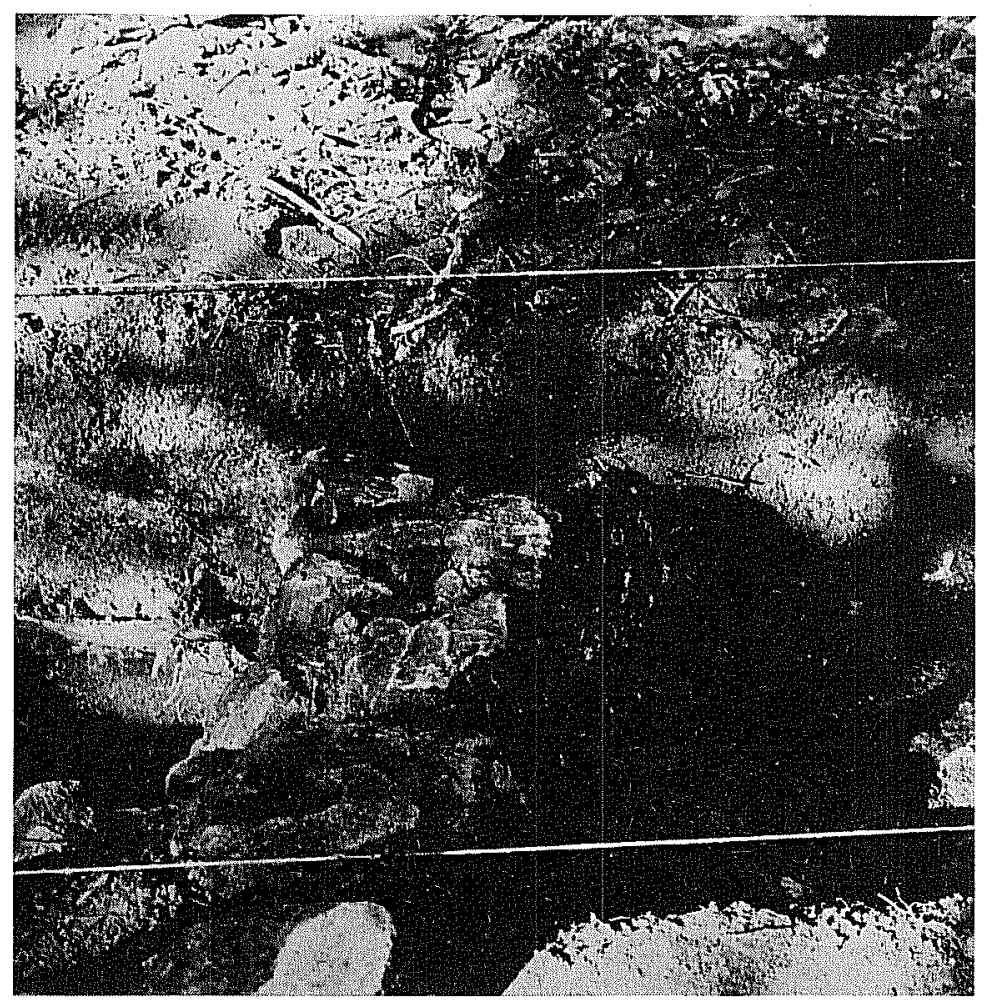

b

Figure 27. Excavations at Steiner Site, Structure 2. a, area before excavation, from the east; $b$, Unit $A$, showing construction of wall footing. 


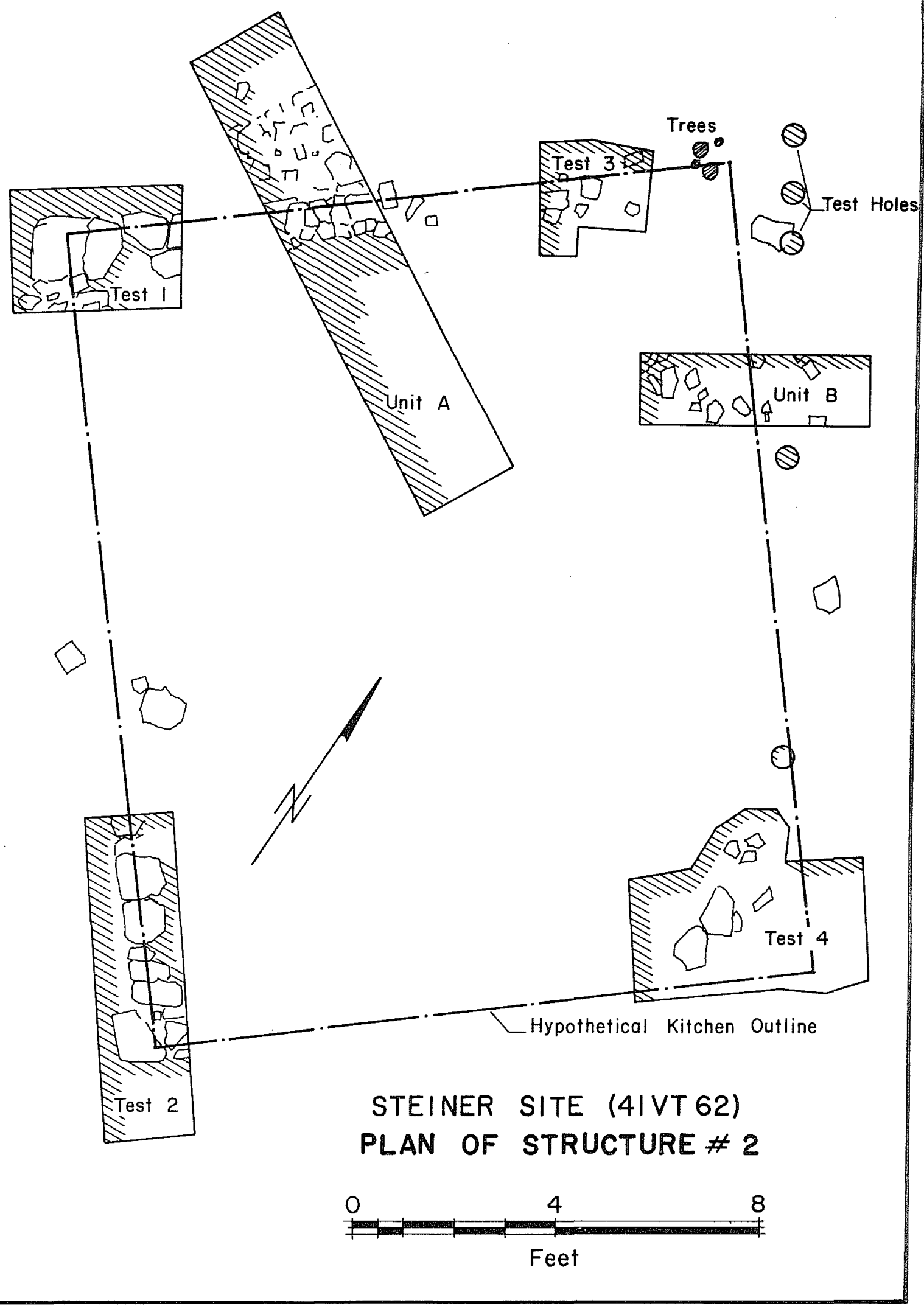

Figure 28. Steiner site (41 VT 62), Plan of Structure 2. 
the unit was a wall foundation consisting of sandstone chunks laid in a double row approximately one foot wide (Fig. 27,b). Most of the artifacts were found just inside this wall.

Beneath the gray clay layer was a deposit of dark brown sand containing rusted nails, large pieces of charcoal and a few artifacts. Beneath this at 27 inches was red, basal clay. Outside the wall the soil consisted of tan, sandy loam with chunks of wall rubble and occasional nails.

Once the width and location of the wall were established, other wall fragments (Tests 1-4) were cleared off to just below the top of the stones, in order to determine the shape and size of the structure. On the east side, where no wall fragments could be found on the surface, Unit B was excavated to a depth of 12 inches. No definite stone construction was present, but the trench profile revealed a change in the soil from the tan, sandy loam on the outside to the lighter tan clay on the inside of the structure at a point near the center of the unit. No indications of the southeast corner remained, but its location could be projected from known wall locations.

\section{Structure 3 - Possible Smokehouse}

In order to determine the size and shape of this structure, the topsoil was removed from an $8 \times 10 \mathrm{ft}$ area where stones could be seen set in place. Within this cleared area, a pattern of sandstone blocks could be discerned. As the soil was troweled from the surface and loose rocks were removed, groups of stones outlined a foundation approximately $7 \times 8 \mathrm{ft}$. Artifacts found in clearing the area included cut nails, animal bones and ceramic sherds. Part of a cast iron griddle (Fig. 29,b) was found outside the north wa 11. An 18-inchsquare excavation in the center of the structure taken to a depth of 12 inches produced no evidence of burning or a constructed fire pit (Fig. 30,a).

The absence of fire pits or burned earth within either of the structures tentatively identified as smokehouses does not preclude their use in that capacity. There could have been an ash bin such as described by Sloane (1967:84) or the fire could have been maintained in an iron pot, as described in Wiggington (1972: 201). The size and construction of the building at the Schob farm suggests that it could have been a smokehouse similar to those described by sloane as "nothing but an airtight little house with a dirt floor."

We11

An essential component of the Steiner farmstead was the we11, located just north of the house (Fig. 22). It was constructed of wedge-shaped sandstone blocks and was $15 \mathrm{ft} 6$ in deep, with an inner diameter of $3 \mathrm{ft} 6 \mathrm{in}$. There is presently no trace of the superstructure which once undoubtedly supported a device for raising water buckets from the well.

\section{Quarry}

A careful survey of the area between the Steiner site and the creek revealed no other surface indications of farm structures. However, in the creek bank 


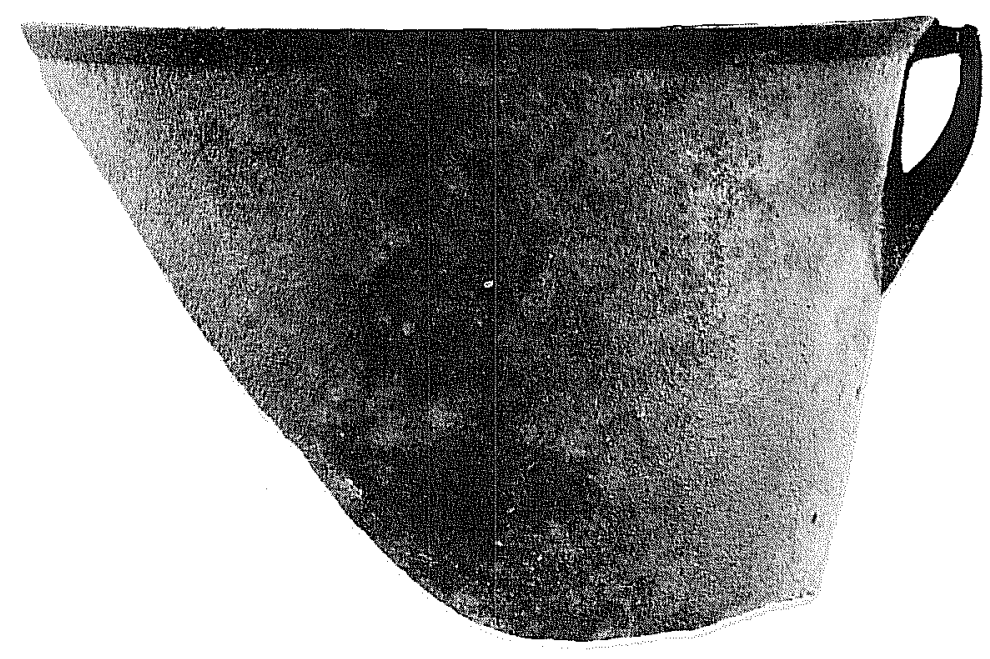

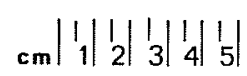

a

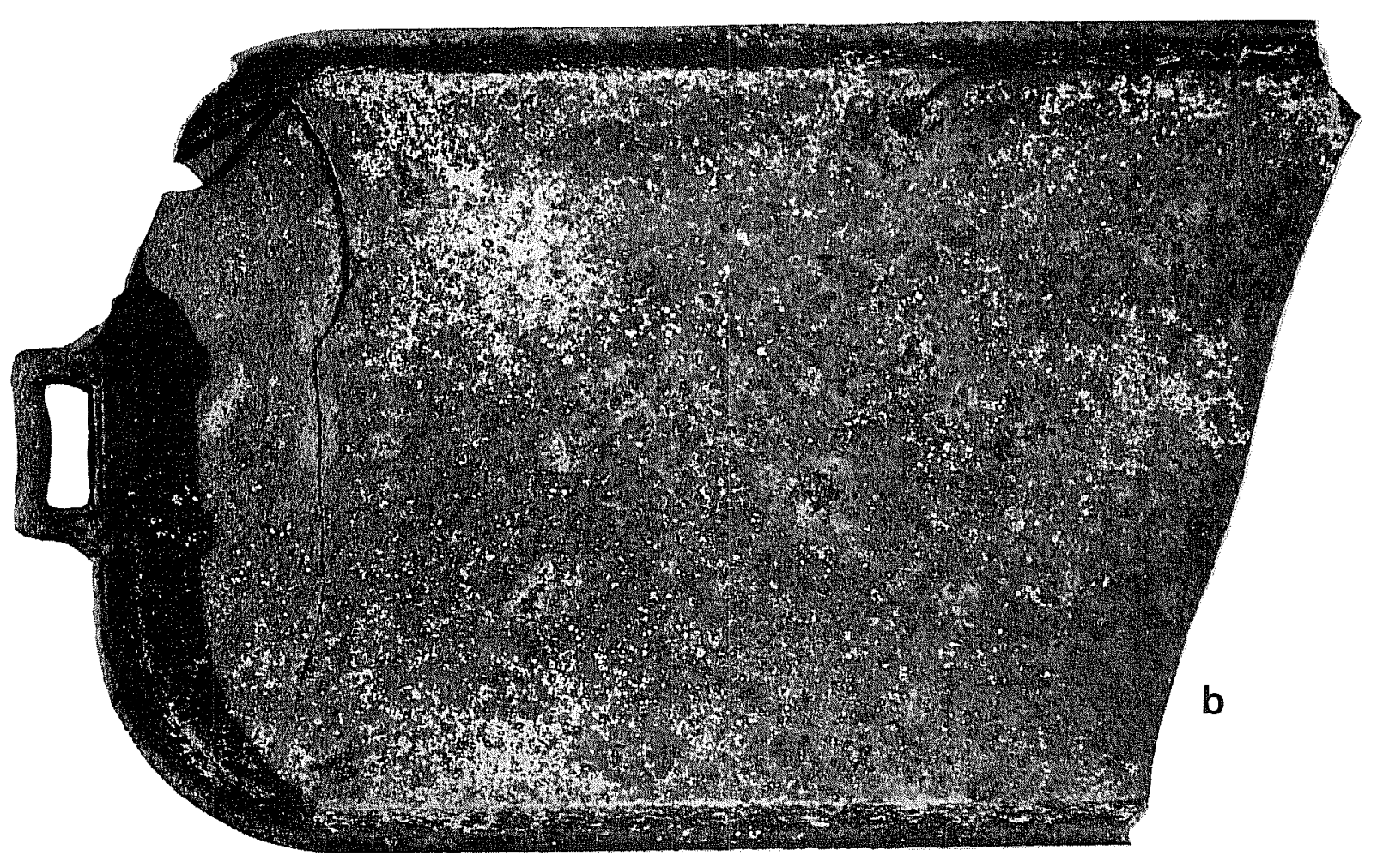

Figure 29. Cast Iron objects from Steiner site. a, cast iron kettle; b, cast iron griddle. 


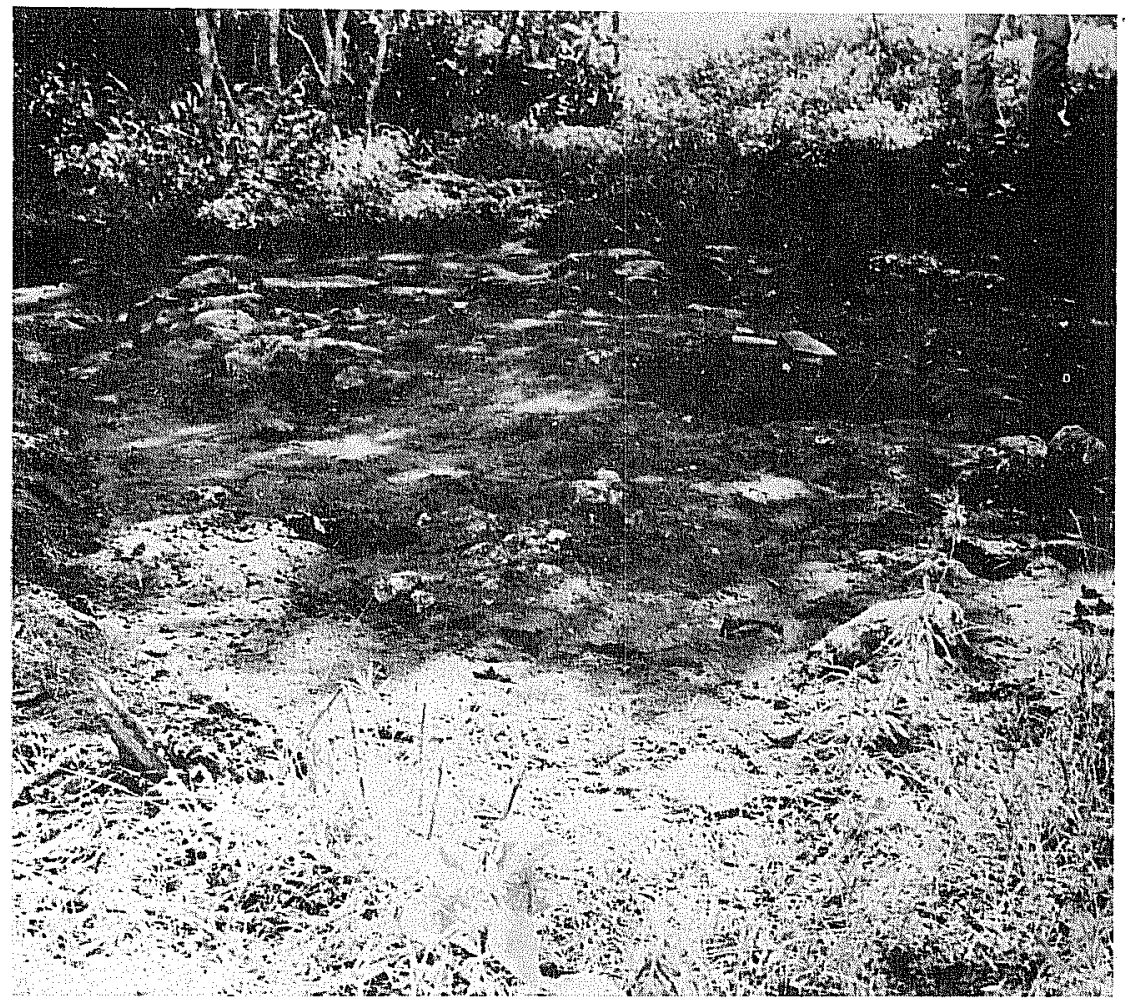

a

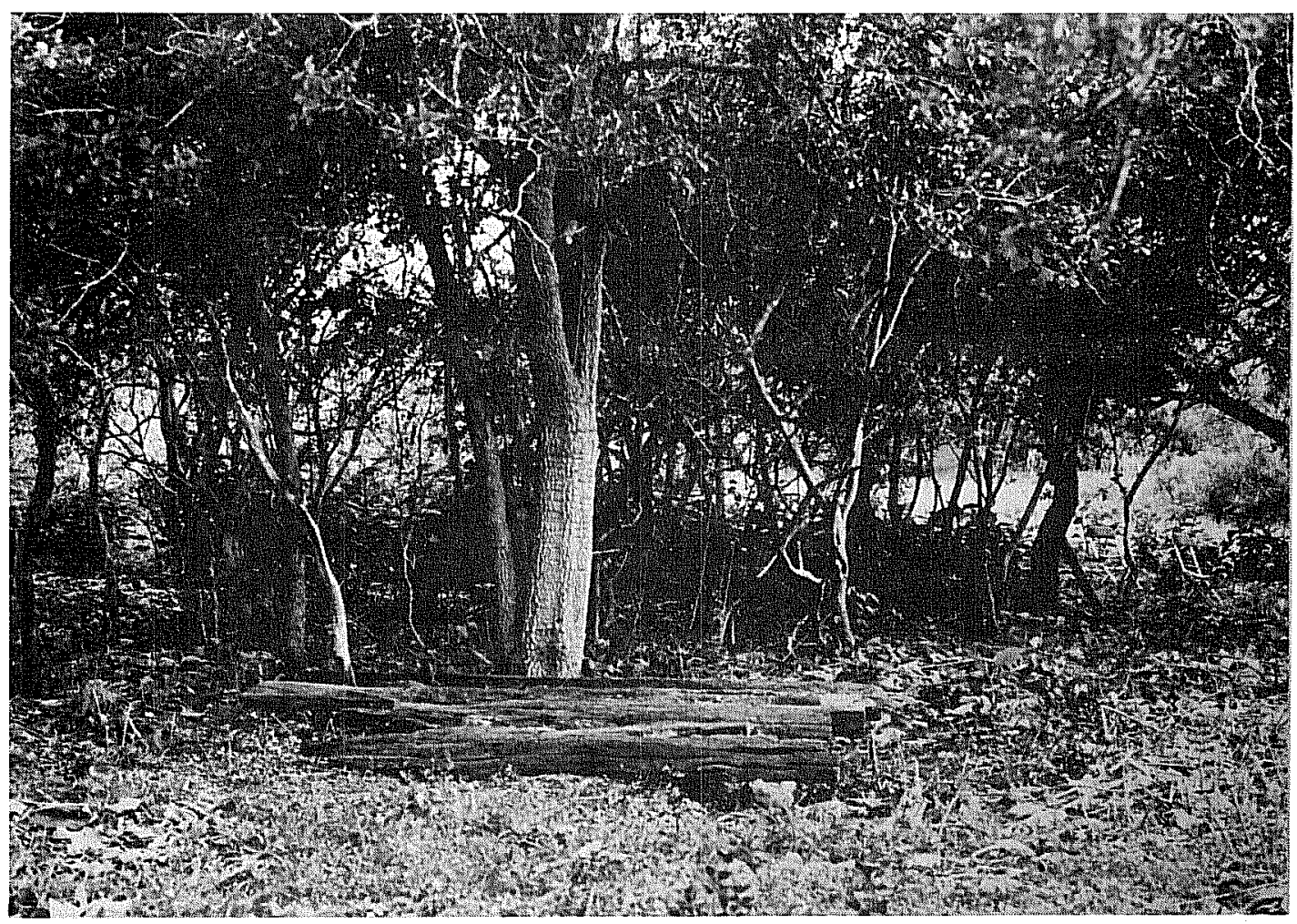

b

Figure 30. Views of Steiner Site Features. a, Structure 3, showing footing remnants and test pit in center; $b$, the we1 1 , covered with hewn logs from the old log barn; picture taken from the house site (Structure 1). 
approximately 700 feet northeast of the house there is an outcrop of tabular sandstone which appears to be the quarry from which the stone for the Schob house was obtained. This may also have been the source of stone for the foundations and chimney of the Steiner house.

\section{Observations}

The location of the Steiner farmhouse at some distance from the creek at first seems puzzling, when permanent water such as that available in the creek should have been an important consideration. However, by this time the earlier settlers had discovered that creek water, no matter how clear, was not necessarily wholesome (Fretel7iere 1934:89). Also, mists rising from the creeks were thought to bring on fevers and other i 17nesses (de Cordova 1969:26).

The farmstead appears to have been laid out in reference to the house, which faced the southeasterly breezes with the corners pointing to the cardinal points of the compass, as dictated by local custom (Crosby 1977:36-37). The chimney and foundations were constructed of local sandstone quarried from the creek bank and laid up with mortar made of creek sand and Time which may have been burned in a kiln nearby. The frame for the house was constructed on the site, hewn from trees obtained in nearby riverbottom lands (Linn 1883:13).

Milled lumber for siding, doors and window frames would have been produced in the coastal area by this time (Crosby 1977:27). However, roads were so poor and transportation so inadequate that settlers found it more economical to ship lumber in from Mobile via the port at Indianola (de Cordova 1969:39). Family tradition holds that the milled lumber for the Steiner house was brought from Indianola. $\mathrm{Nails}$ and window glass were brought in by wagon from coastal ports, probably also from Indianola. Hardware was made by a local blacksmith. Roofing was probably shingles, which were locally available at the time.

Any changes or additions to the house would have used similar materials, as there were few major advances in the technology of building between the time of construction of the house and its removal around 1880. When the house was moved, apparently the porch and siding were removed. It may be that the framing members were numbered at this time and that the entire frame was dismantled to be reconstructed on the new site. Deposition and subsequent disintegration of these materials on the west half of the house foundation would account for the mound over the area which contained layers of paint and numerous nails. A similar operation at the kitchen could account for the mound over that site as well. To reinforce this suggestion, fragments of a wine bottle were found in the same level as the paint fragments in Unit $B$; more pieces of the same bottle were found near the bottom of the cellar in Unit $C$. This suggests that the bottle's contents may have been consumed during the dismantling and removal of the house, and may have preceded or accompanied the piling of the residue onto the old foundation.

The kitchen to the northeast would probably have been built in a similar manner to the house, as this was the prevailing type of construction in the area at the time (Crosby 1977:39). Pieces of the frame of the old kitchen may have been reused in the later construction of the Schob kitchen, as framing timbers beneath that structure show signs of multiple reuse. The types of artifacts found 
beneath and around this structure--i.e., milk bowl, food containers, dishes, fork and tumbler (Table 2)--reinforce the family tradition that it was the kitchen. The comparatively early dates of manufacture of these items suggest that the kitchen was built at about the same time as the house.

The small structure to the west of the house and kitchen could have been the smokehouse. The size of the foundation would accommodate the present guinea house at the Schob site, if indeed that is the original structure. However, it may be that the size was merely found adequate for the purpose and an identical smokehouse was erected at the new site.

\section{The Artifacts}

Hous ehold I tems

Ceramics

Porcelain

Plain white, thin $\left(1 / 16^{\prime \prime}\right)$, plate (Fig. $\left.31, d\right)$

Plain white, heavy $\left(3 / 16^{\prime \prime}\right)$, cup (Fig. 31,e)

Hardpaste earthenware

Cream paste, lid $\mathrm{Ca} .4-3 / 4 "$ diameter and plate; inside of plate has numerous knife scars (Fig. $32, \mathrm{C}$ )

Pearlware

Purple transfer design, cup and plate (identical pattern to sherd found in Schob kitchen excavations, see Fig. 33,a)

No decoration, plate, pitcher

Purple floral handpainted design, bowl and plate (Figs. $31, g ; 33, f$ )

Red floral handpainted design, bowl ca. 4-1/4" diameter (Fig. 32,a)

Red, green and black floral handpainted design, plate (Fig. 32,b)

BTue and brown bands, bow1 6" diameter (Figs. $31, \mathrm{c} ; 33, \mathrm{i}$ )

Irons tone

Undecorated, includes heavy molded cups, plates and bowl or pitcher

(Figs. 3],f; 32,d,e; 33,d,e,g,h)

Stoneware

Cream paste with thin lead glaze inside only, one

Gal1on milk bowl, early 19th century shape (Fig. $36, \mathrm{~h}$ ) 


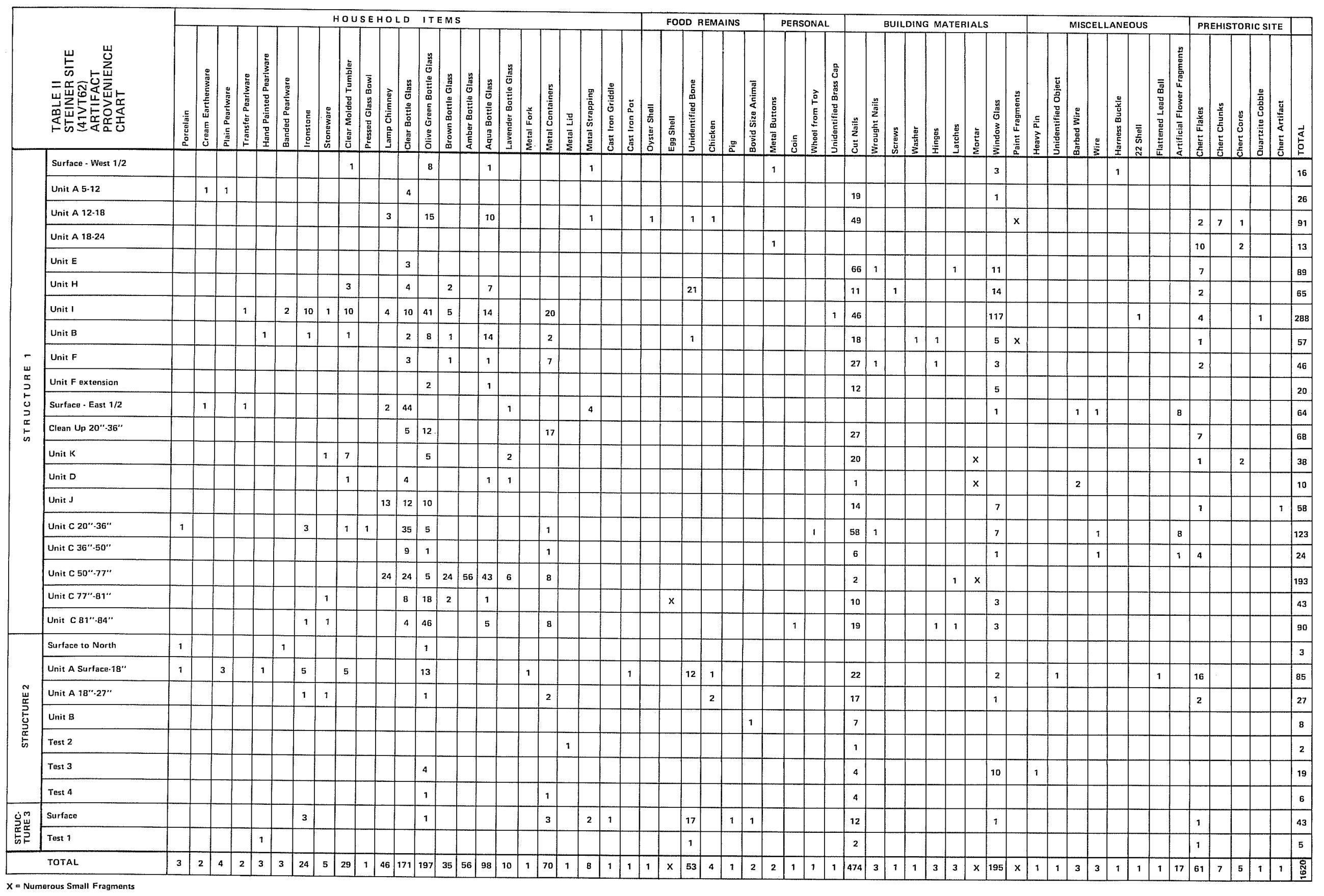



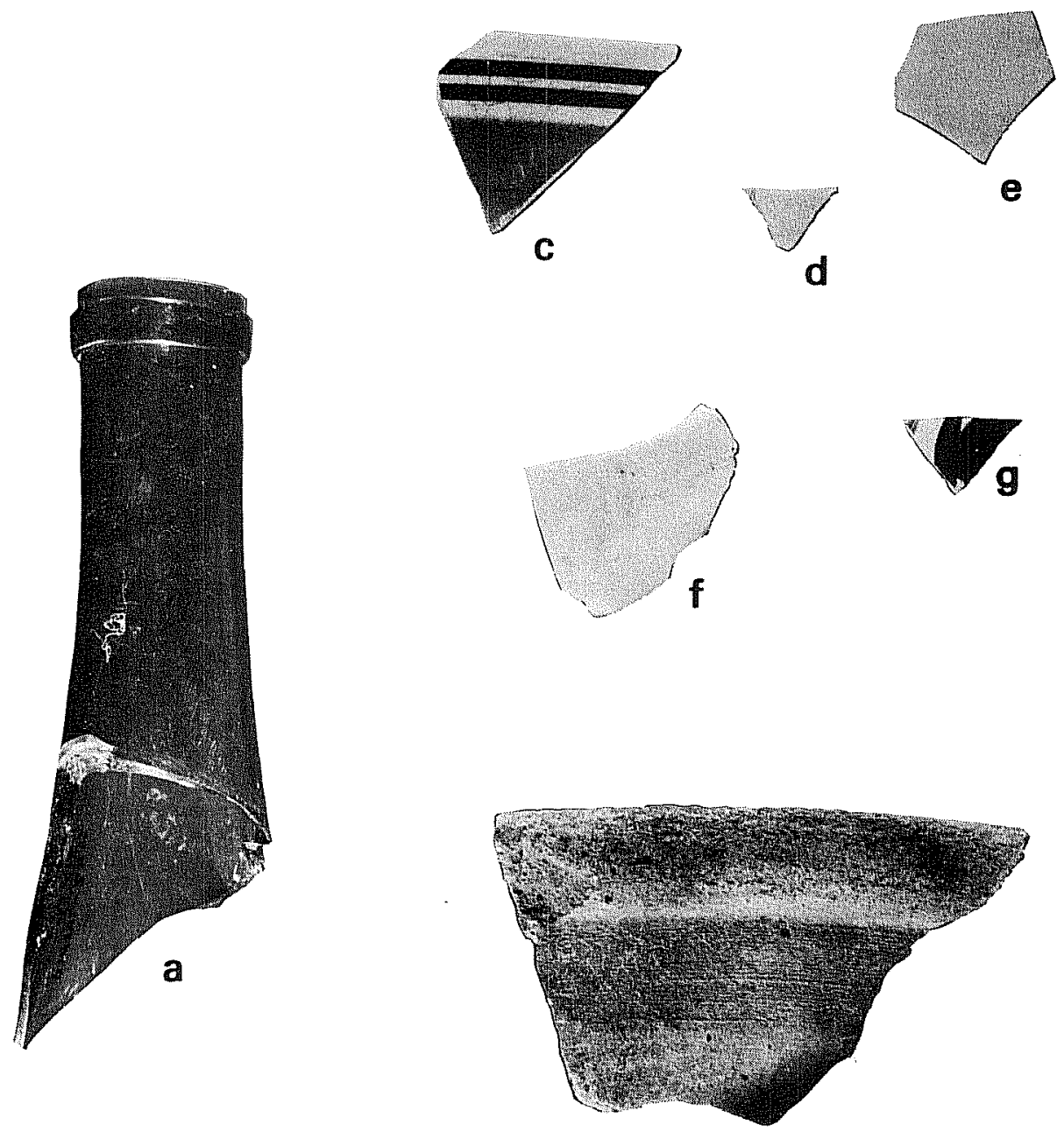

h
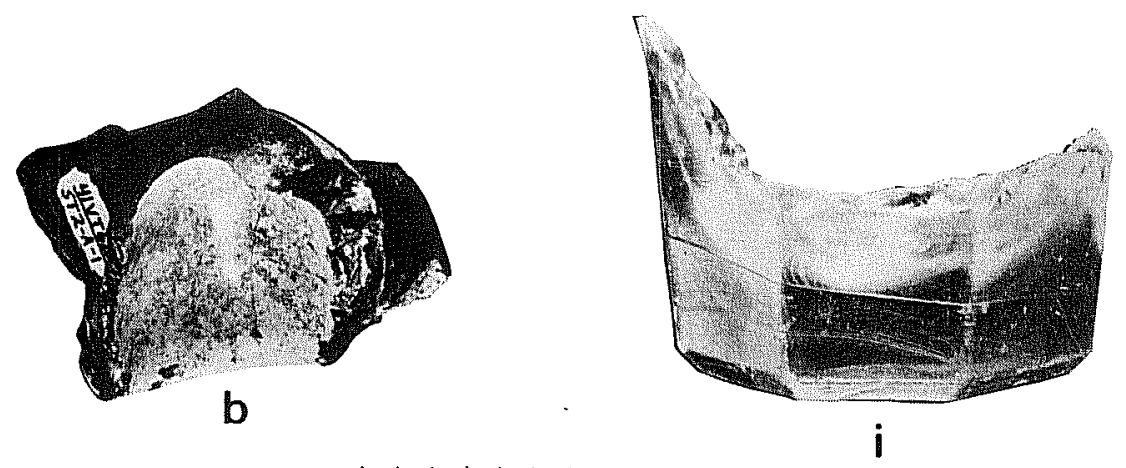

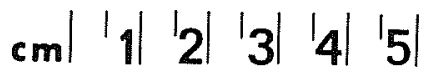

Figure 31. Glass and Ceramics from Steiner Site, Structure 2. a, 01ive wine bottle neck, sheared lip, applied ring; b, olive wine bottle base; $c$, banded pearlware bowl; $d$, thin porcelain plate; $e$, heavy porcelain cup; $f$, ironstone cup; $g$, purple handpainted pearlware cup or bowl; $h$, stoneware milk bowl; $i$, pressed glass tumbler. 


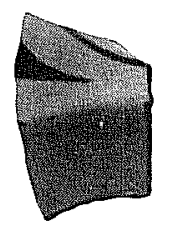

a

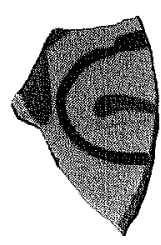

b

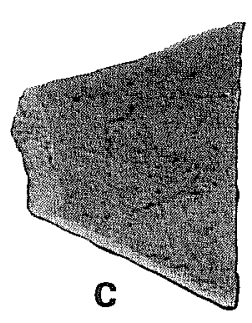

C
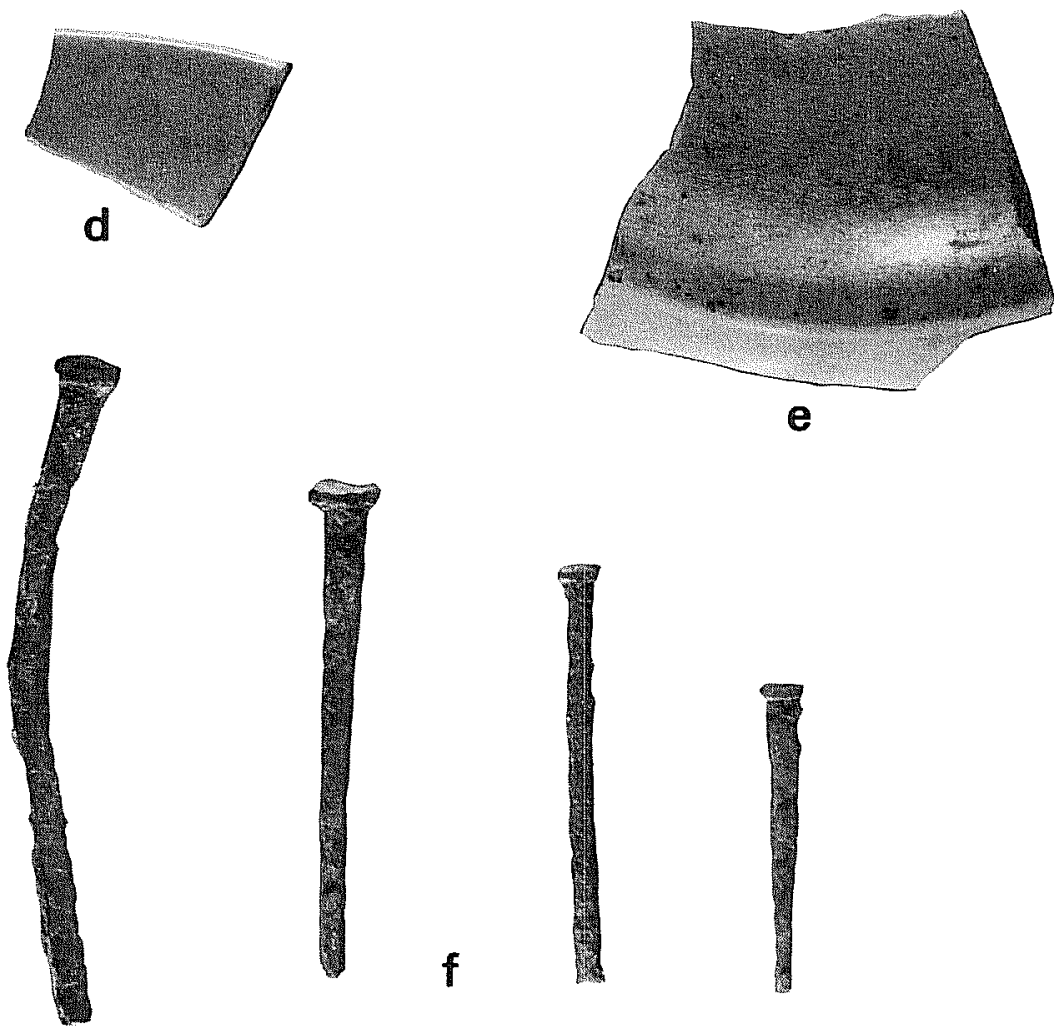

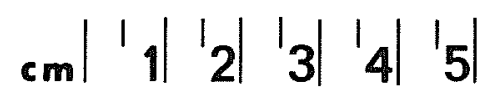

Figure 32. Artifacts from Steiner Site, Structure 3. a, red painted peariware bowl; b, red, black and green handpainted pearlware plate; c, cream earthenware plate; $d$, ironstone plate; e, ironstone pitcher base; f, cut nails. 

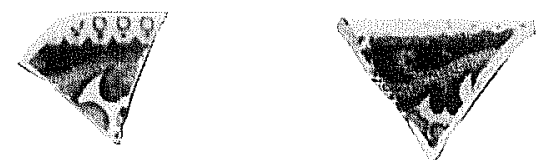

a

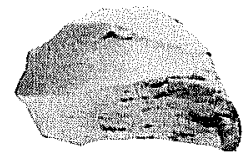

b
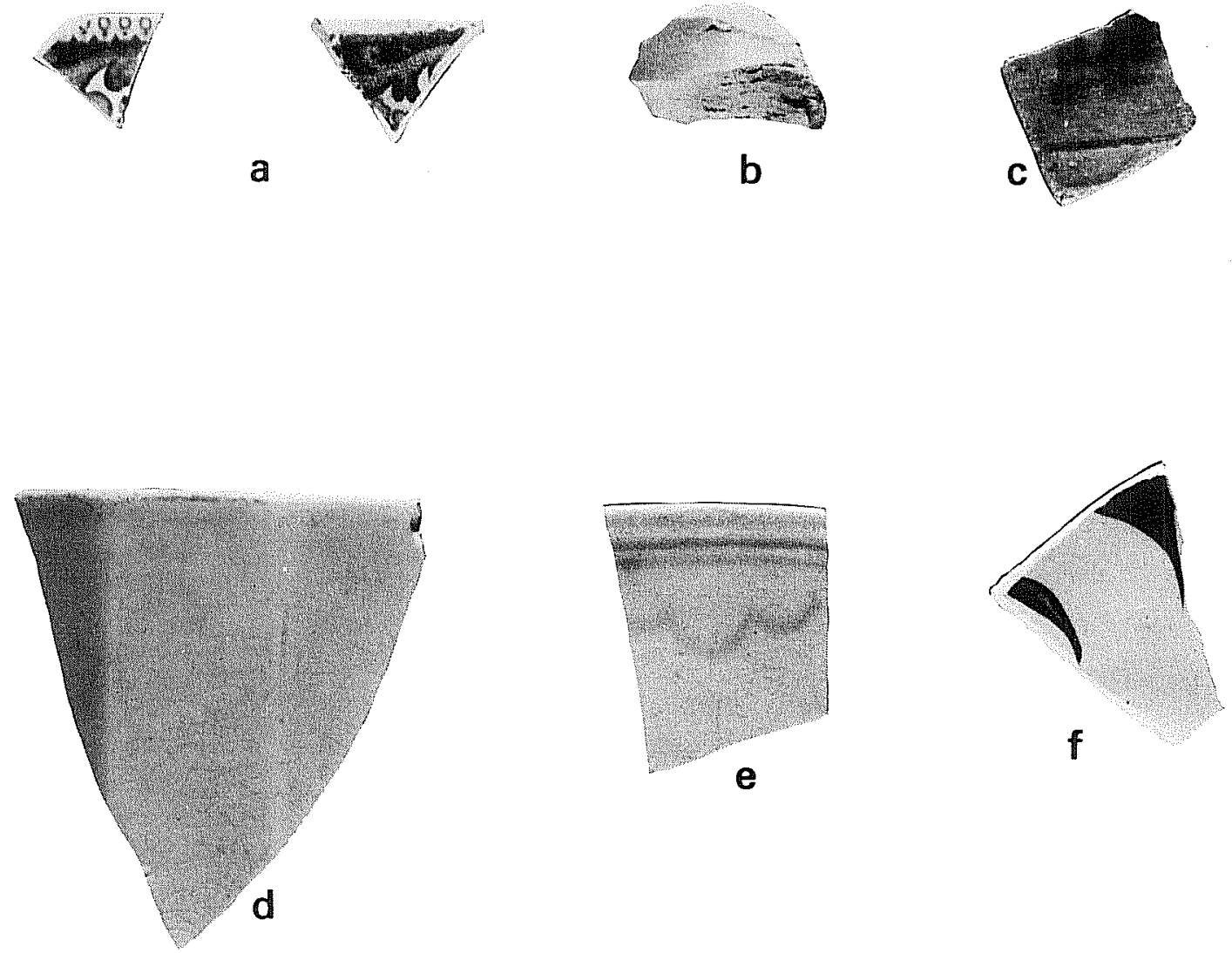

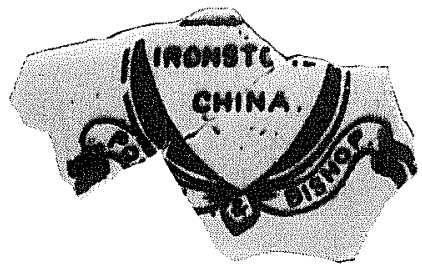

g

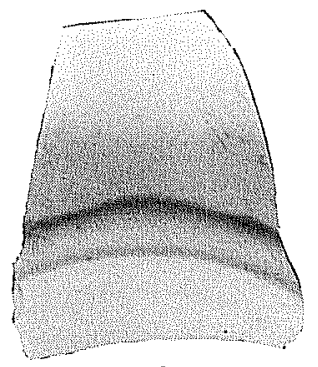

h

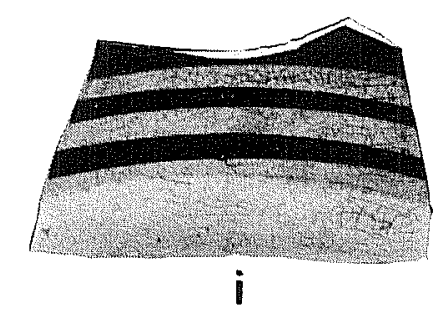

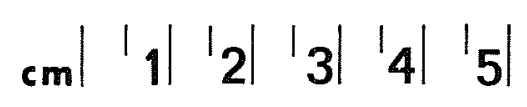

Figure 33. Ceramics from Steiner Site, Structure 1. a, purple transfer pear 1ware showing inside of plate rim (1) and outside of cup rim $(r) ; b$, stoneware jug neck; c, stoneware preserve jar; d, ironstone cup; e, ironstone cup or mug; $f$, purple handpainted pearlware plate; g, ironstone plate, marked "Powell \& Bishop"; $h$, ironstone cup base; $i$, banded pearlware bowl. 
Tan paste, Albany slip inside, pinkish tan glaze

Outside, jug neck, late 19th century (Fig. 33,b)

Gray paste, Albany slip outside, alkaline glaze inside, preserve jars, middle to late 19 th century (Fig. 33, c)

The types of ceramics found at the Steiner site were similar to those found at numerous other central and south Texas sites of the 1850-1880 period, probably reflecting the virtual monopoly of the few import houses supplying the coastal towns at that time (Carter and Ragsdale 1976:113). The imported wares, al1 made in England, included pearlware with various types of decoration which was popular in the south Texas area when the Steiners arrived in 1850, and ironstone which became the prevalent ware in use when the coastal ports reopened after the Civil War.

Stoneware utility vessels such as crocks, jugs and milk pans were made in Texas in the mid-19th century. The milk bow? rim sherd found under Structure 2 is particularly interesting because the shape of the rim is typical of vessels made in the early part of the century in the southeastern United States, and because of the presence of a lead glaze. The only currently-known potter making similar vessels in Texas was Abraham Babcock, who was operating on Mustang Creek in Jackson County between 1850 and 1860 (Georgeanna Greer, personal communication). However, a careful comparison of this sherd with samples from Babcock's kiln site has revealed that the paste and rim shape are subtly different from his work. This could be an indication that there was another potter working in the area at the same time, or that the vessel could have been brought in from a shipping point in the South, such as New Orleans. The other stoneware sherds present are typical of vessel shapes and glazes in use by Texas potters in the third quarter of the 19th century.

Glass

Tableware

Pressed glass tumblers, at least five different vessels represented (Figs. $37, i ; 34, g ; h$ )

Fragment of pressed glass bow1, too sma 11 to determine the pattern (Fig. 34, C)

The tumb Ters represented by fragments found in Structures 1 and 2 were a 11 similar in shape and size, in a pattern popular from 1840 to 1860 (McKearin and McKearin 1941:394-5).

Containers

Clear Glass

Neck and shoulder of heavy blown-in-mold jar with round neck and octagonal body, machine-finished rim. A similar documented jar is 7-1/8" high (Adams 1971:76), 1860-1880 (Fig. 35,b) 


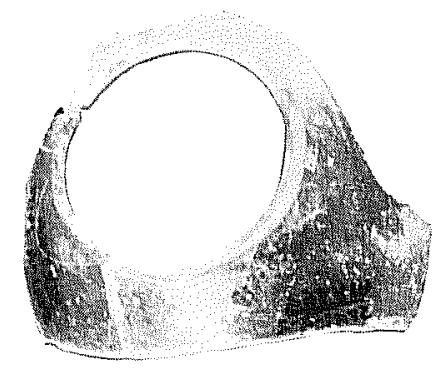

a
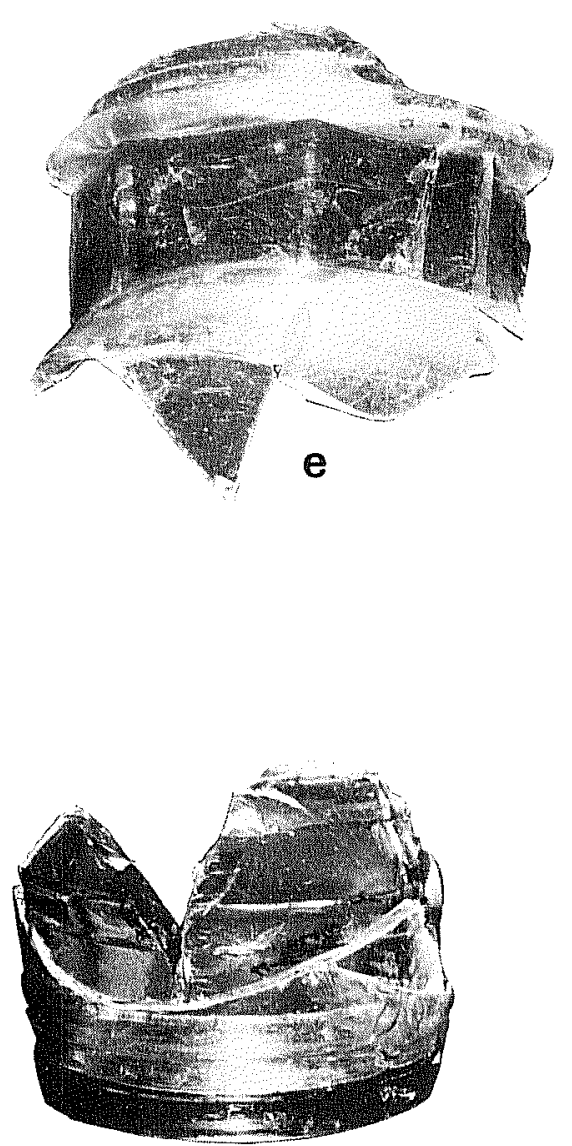

f
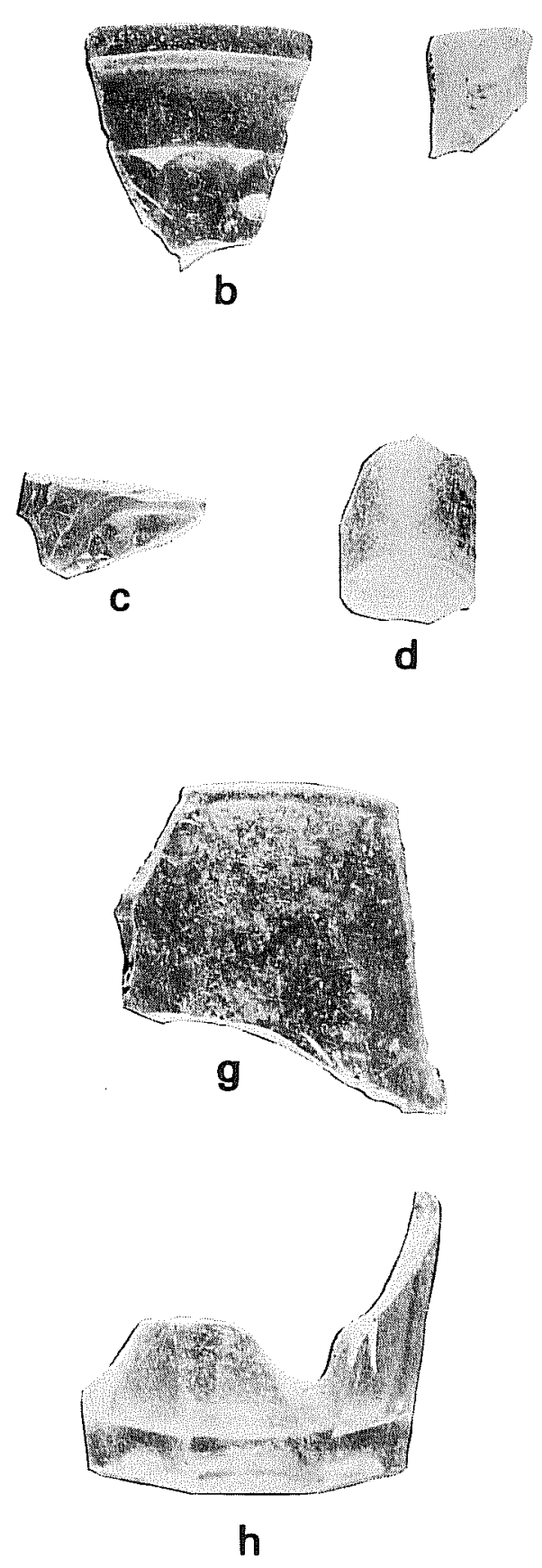

h

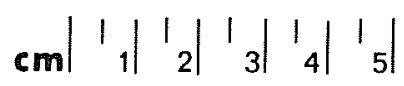

Figure 34. Glass from Steiner Site, Structure 1. a, lamp chimney or globe; $b$, molded container with rough rim; $c$, pressed glass bowl; d, small bottle with sheared lip; $e$, jar with faceted neck; $f$, mustard jar; $g$, pressed glass tumbler rim; $h$, pressed glass tumbler base. 


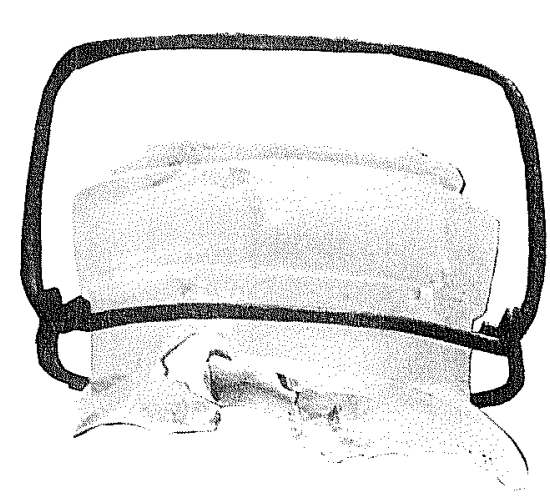

a

C

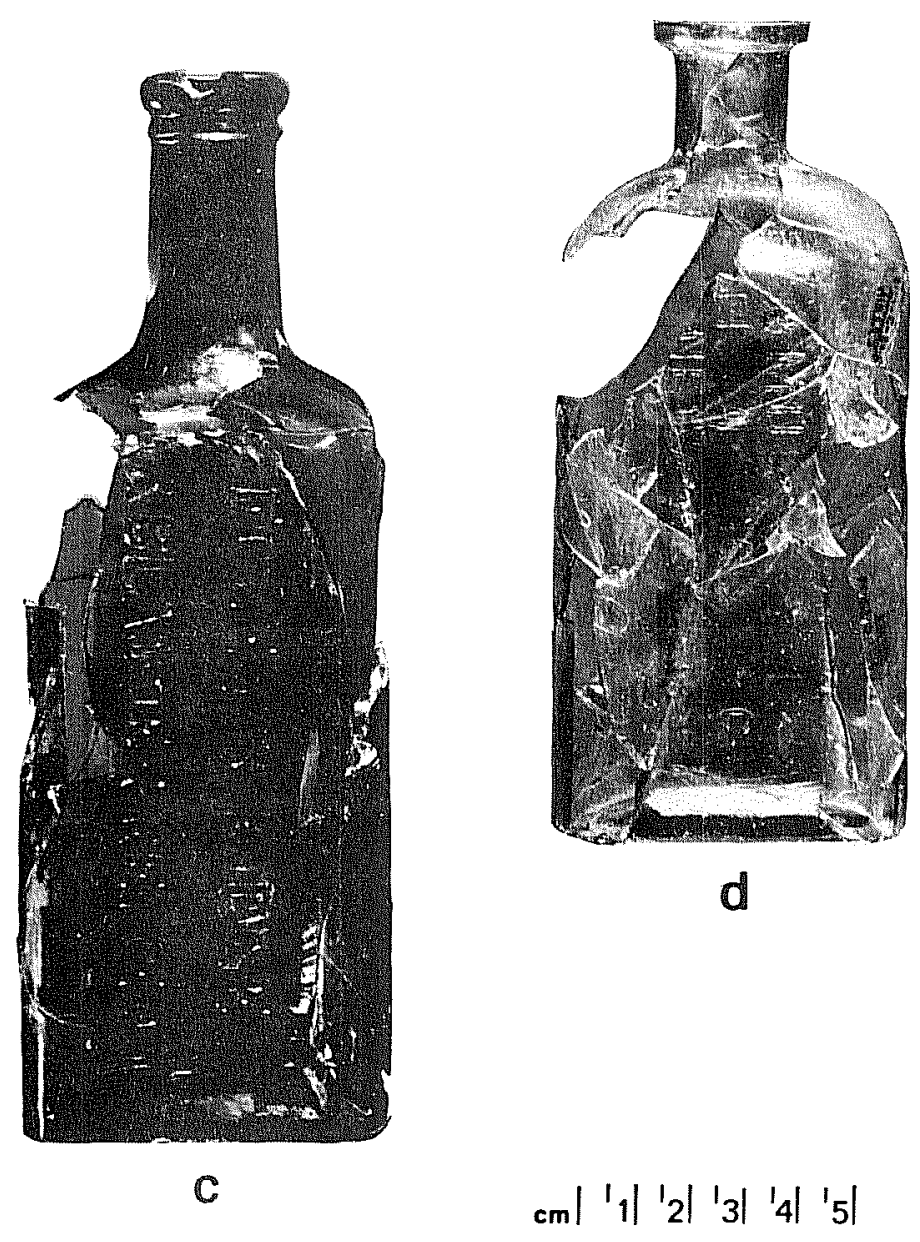

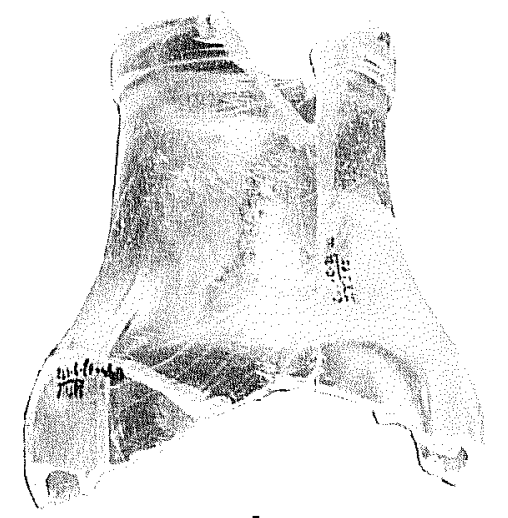

b

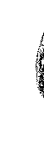
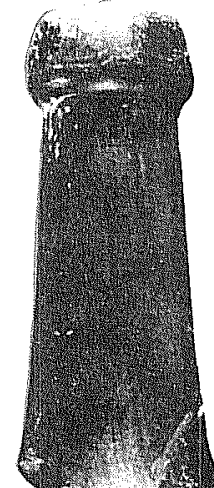
Neck and shoulder of molded jar with 10-faceted neck, round body, no datable details

Neck of molded jar with seam through 7 ip, made after 1900

Neck and base of canning jar with metal clamp, 3-1/2" diameter at base, Owens ring on bottom, after 1903 (Fig. 35,a)

Neck and shoulder of molded jar with eight-faceted neck, round body, maximum diameter 3", no datable details (Fig. 34,e)

Rim fragment of molded cylindrical container, 3" diameter at rim, no datable details. Rim is too rough for a drinking vesse]

(Fig. 34, b)

Bottle base marked "...DESIGN PAT'D...," with 4" center, Owens ring, made after 1903

01ive Green Glass, A11 Wine Bottles

Neck with sheared Tip and laid-on ring, ca. 1840 (Fig. 31,a)

Base of free-blown bottle of irregular shape, deep kickup, no pontil mark, made after 1857 (Fig. 31,b)

Restorable bottle, turn mold finish, tooled lip, made ca. 18801890 (Fig. 35,e)

Brown Glass

Bottle neck with mold mark to within $3 / 4$ " of lip, tooled lip, $1860-1880$

Restorable panel bottle, "FOLEY'S KIDNEY \& BLADDER REMEDY/FOLEY \& CO./CHICAGO, U.S.A." on three sides. Identical bottle advertised in Emporia (Kansas) Daily Gazette, April 6, 1897

(Ba7dwin 1973:185) (Fig. 35,C)

Amber GTass

Restorable panel bottle, "MUL-EN-OL" embossed on front, 1870-1900 (Fig. 35, d)

Aqua Giass

Neck of condiment bottle with seam to just under Tip, tooled 1ip, $1860-1880$

Neck fragment of food storage jar, seam to just under lip, tooled 1ip, $1860-1880$

Sma 11, irregular-shaped, free-blown bottle neck, sheared 1ip, 1860-1880 (Fig. 34,d) 
Sma11, irregular-shaped bottle, two raised dots on bottom

Bottle base, Owens ring, two raised dots, 3-1/8" diameter, after 1903

Bottle base, molded, "35" embossed in center, 4-1/4" diameter, early 20 th century

\section{Lavender Glass}

Jar base, barrel-shaped with embossed rings around the body, 2-1/4" diameter

Similar to jars illustrated in Yount (1967:56), Switzer (1974:49) and I17inois Glass Company (1903:46) which contained mustard, probably late 19th or early 20th century (Fig. 34,f)

Base of food container, 2-3/4" diameter, indistinct symbol or letter embossed in center, probably after 1900

Glass bottles and food containers have been dated according to details in the way they were made, and well-known dates for various improvements in manufacturing techniques, as follows:

The sheared lip, in use up to 1880, was given a laid-on ring after 1840 (Kendrick 1963:48).

The snap case, eliminating the ponti1, was invented in 1857 (Lorrain 1968:40).

The lipping tool was used from 1860 to 1880 (Kendrick 1963:48).

Bottles with embossed lettering were popular from 1870 to 1900 (ibid.:71).

Turn molds were commonly used from 1880 to 1890 (Kendrick 1963:43).

The machine-made bottle with mold seam through the lip first appeared in 1900 (ibid.:48).

The Owens bottle-making machine was invented in 1903 (Kendrick 1963:83).

Lamp Globes or Chimneys

Opaque white, globular shape

Clear, plain chimney shape (Fig. 34,a)

Clear, embossed on rim "...WLERS PATENT..."

The first lighting in the Steiner home may have been from candles, since the City Council chamber in Victoria was so 1 ighted in 1850 (Victoria Sesquicentennial 1974:12). However, various types of oil lamps with chimneys were coming into use by the middle 1850s (Yates and Yates 1949), and by the 1880s opaque glass globes were popular. 


\section{Tableware}

Three-tined metal fork (handle and fragments), handle is $3-1 / 4$ " long (Fig. 36,e)

Metal

Containers

Fragments of tin can with crimped-on lid (Fig. 37,i)

Can cap, 1-1/2" diameter, smal1 hole in center (Fig. 37,h)

Numerous fragments of thin metal from cans were present in all the structures. Invented in the early 1800s, tin cans were made with a hole in the top through which the food was forced. A pin hole in the cap let the gasses escape, after which the hole was sealed with a drop of solder. This type of can was in popular use unti1 1900 (Fontana and Greenleaf 1962:68-69).

Cap

Press-on friction 1id for glass or metal food container, 2-1/4" diameter; similar to ones found at Anderson's Mi11, a late 19th century site in Travis County (Durrenberger 1965:55) (Fig. 36,b).

Strapping

Fragments of metal strapping $1 / 2$ " to $1-1 / 4$ " wide

Most shipping in the 19 th century was done in wooden boxes, casks and barrels held together and reinforced by metal straps. Nineteenth century sites generally contain numerous fragments of this strapping.

Cast Iron Vessels

Cast iron kettle fragment, projected diameter $11^{1 "}$, thickness $1 / 8^{11}$

(Fig. 29,a)

Cast iron griddle, one end broken off, projected length 23", width 10-1/4", thickness 1/8"; five smal1 projections on bottom (Fig. $29, b$ )

Cast iron hollow ware has been an important part of kitchen equipment for several hundred years (McClinton 1951:97), due to its strength and heat-retaining qualities. Shapes and handle details have evolved through time, but the basic pot, kettle and skillet or griddle are not appreciably different today than they were when the first settlers arrived on this continent. The kettle fragment found on the surface near Structure 2 indicates by its light weight and inward-curving ear or handle attachment that it was made of post-Civil War coke iron, and would have had a recessed bottom and three stubby legs to fit on the kitchen stoves of that period. A similar one was sold in the 1890s by Sears, Roebuck \& Co. (1968:129). The griddle, also called a flat iron heater in the 1890s (ibid.:129), would have had a number of household uses, even after it was broken. 

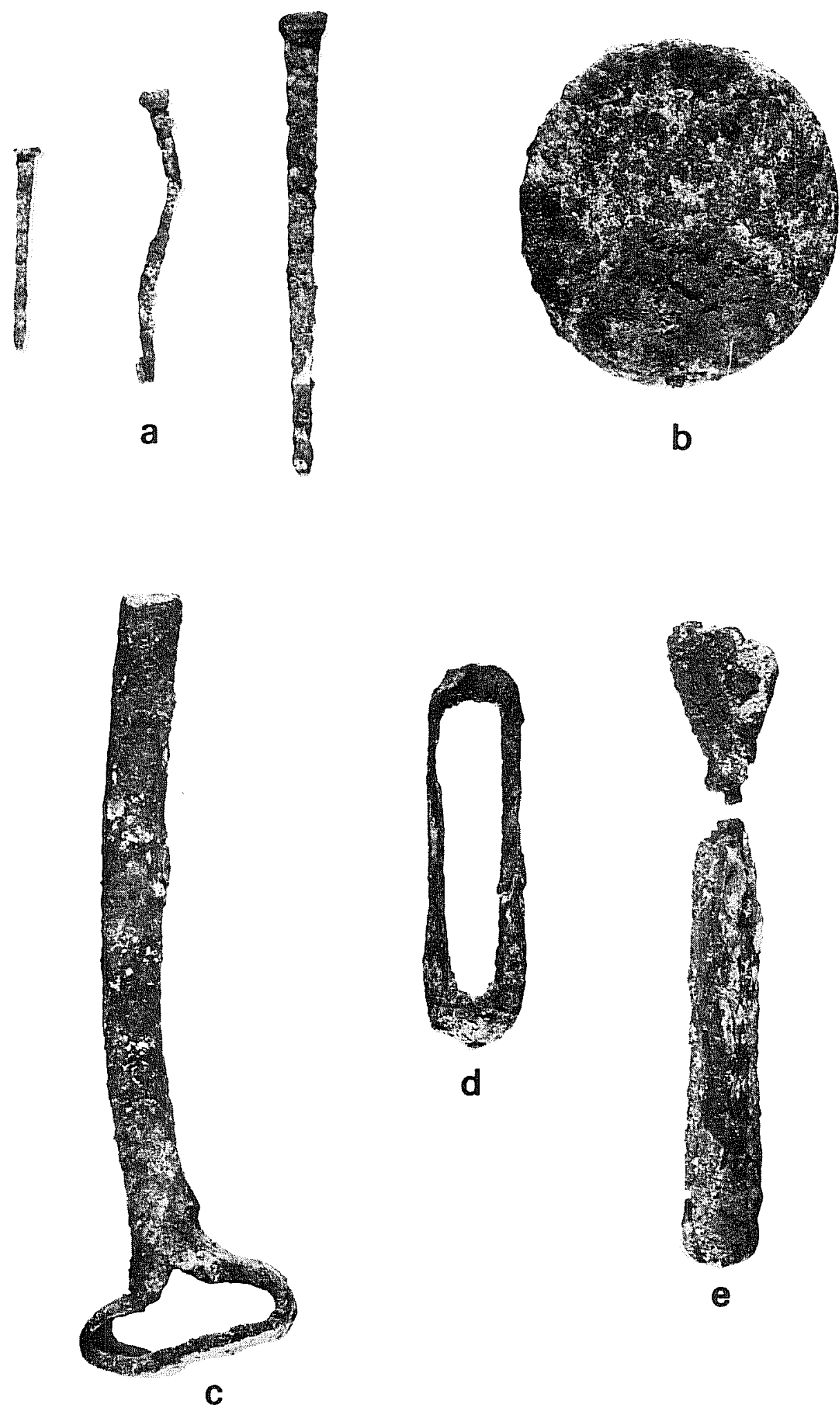

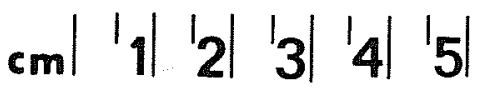

Figure 36. Metal Artifacts from Steiner Site, Structure 2. a, cut nails; b, metal 1 id; $c$, hand-forged rod with loop; d, unidentified metal object; e, three-tined fork. 


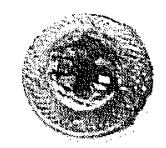

a

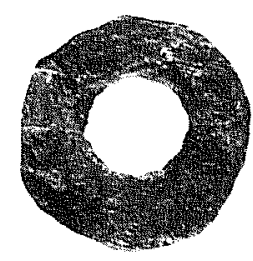

d

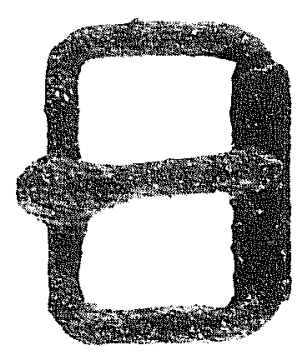

g

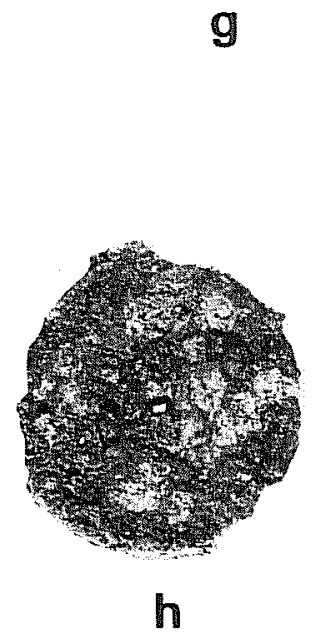

h

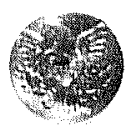

b

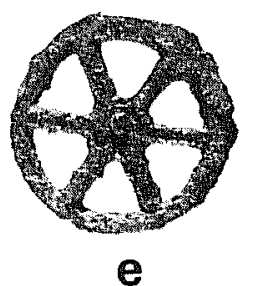

e

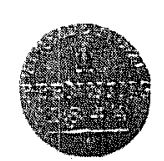

C

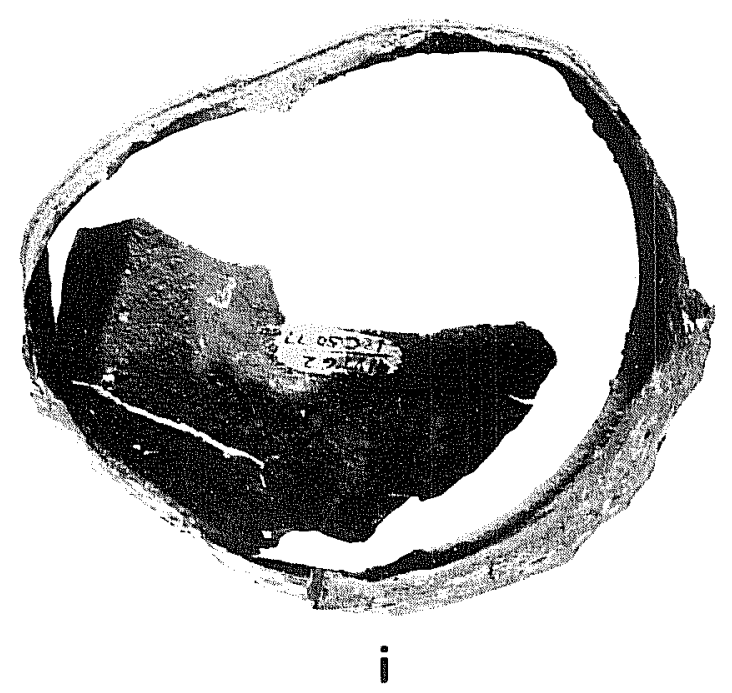

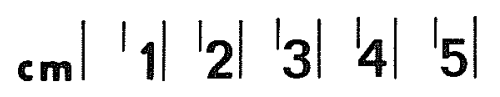

Figure 37. Metal Artifacts from Steiner Site, Structure 1. a, metal button; b, U. S. Army button; c, German coin, 1844; d, washer; e, wheel; f, brass cap; $g$, harness buckle; $h$, tin can cap; $i$, tin can. 


\section{Food Remains}

Adult chicken (Gallus gallus), tarsometatarsus and tibia, plus unidentified fragments

Adult domestic pig (Sus scrofal, tooth

Bovid size bone fragments

Numerous unidentifiable fragments

Egg she11, probably chicken

Oyster she11

Chickens were present on any 19th century German farm (Jordan 1966:92). A7 though we have no information about the types and numbers of fowl kept by the family, we do know that pigs and cattle were an important resource for the Steiners and Schobs (see Table 3). The presence of one or more dogs may account for the fragmentary condition of the bovine bone sample.

Raw oysters were a popular food item throughout south Texas in the mid-19th century and were transported as far inland as San Antonio in some quantity (Vinton 1858). Their presence on a site this near the coast is not surprising.

\section{Personal Items}

Button, stamped, two-piece, white metal face with iron back (Fig. 37,a)

Button, brass U.S. Army, no manufacturer's name, no letter of service; type in use up to Civil War (Brinckerhoff 1965:73) (Fig. 37,b)

Coin, one Pfenning, 1844 (Fig. 37, C)

Wheel from toy, 1 " diameter. Toys with similar spoked wheels in Montgomery Ward \& Co. Catalogue (1969:226-229) (Fig.37,e)

Brass object (unidentified), possibly from pencil or pen, 3/8" diameter, unpierced projection on tip (Fig. 37,f)

There were surprisingly few personal items found on the Steiner site, perhaps due to the size and location of the areas sampled. Some of the articles are of particular interest, as they provide a glimpse into the personal lives of the family. The stamped, four-hole metal button is not an unusual type for the middle to late 19th century (Montgomery Ward \& Co. 1969:86). The U.S. Army button probably was brought home by Friedrich Schob when he returned from the Civil War. The coin was probably dropped during construction of the cellar. Such money would not have been too highly prized except for sentimental reasons, since the economy of the times was based more on barter than on cash. The whee 1 could logically have come from a toy belonging to a child of the Schob household in the late 19th century. 


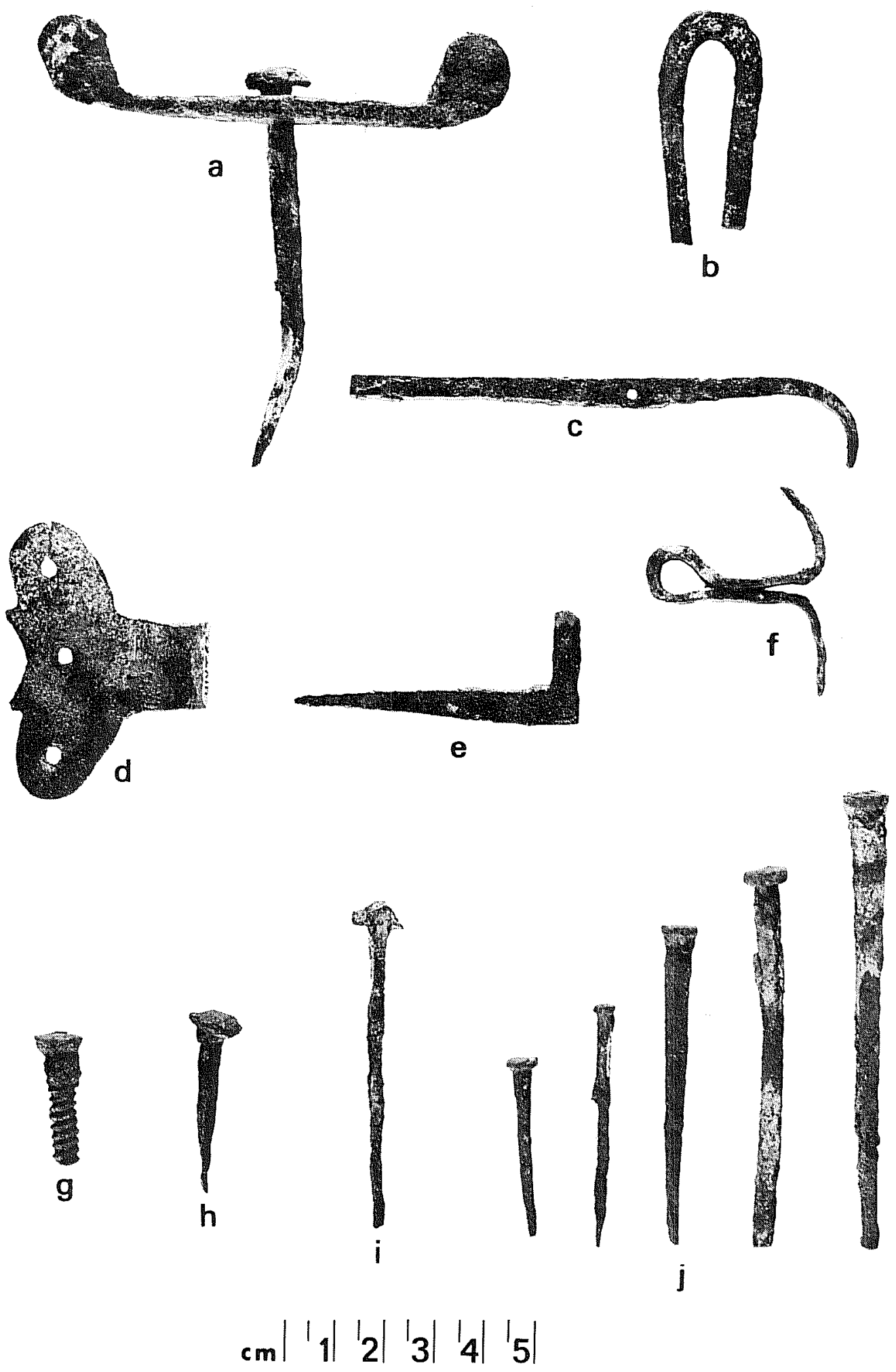

Figure 38. Hardware from Steiner Site, Structure 1. a, latch; b, staple or eye; $c$, latch; d, butterfly hinge; e, hinge pintle; $f$, loop hinge; $g$, screw; $h$, handforged nail; $i$, hand-forged nail; $j$, cut nails. 


\section{Building Materials}

Cut Nails

Common type, $1-3 / 8$ " to $3-1 / 2$ " long ( $1-3 / 8^{\prime \prime}$ most numerous)

(Figs. 32,f; 36,a; 38,j)

Cut nail with handmade head (Ne1son 1968) (Fig. 38,i)

Wrought Nails

Crude, uneven heads; one is incomplete, the other is $1-5 / 8$ " long

(Fig. 38,h)

Screw

Flat-headed screw with blunt tip, 1" long (Fig. 38,g)

Washer

Handmade washer, overlapping ends, 1-1/8" diameter (Fig. 37,d)

Hinges

Hand-wrought loop hinge from cupboard or window (Fig. 38,f)

Handmade butterfly hinge, probably from furniture (Fig. 38,d)

Pintles, simple L-shaped, 2-1/8" long (Fig. 38,e)

Latches

Door latch, 4" long (Fig. 38, c)

Heavy handmade staple or eye with thinned ends, overall length 1-3/4" (Fig. 38,b)

Mortar

Chunks of sandy mortar containing fragments of 1 ime and charcoal Window Glass

Clear, slightly patinated flat glass fragments, varying from $1 / 16^{\prime \prime}$ to $3 / 32^{\prime \prime}$ in thickness

Paint

Fragments of white and gray paint or gesso

As expected, the majority of the nails used in the construction of the Steiner house and outbuildings were machine-cut and machine-headed, a type which had 
been made since about 1830. It was not until the last quarter of the 19th century that wire nails came into general use (Noel Hume 1970:254). The cut of nail with handmade head is identical to those described by Nelson (1968) as in use from 1790 to the mid-1820s or 1830s. The two hand-wrought nails may have been from battened doors or hinges, for which the nails must be clinched or bent over (SToane 1967:62). Machine-made nails were apt to break in these circumstances, and hand-wrought nails continued to be made for this specific purpose up to 1870 (Vates and Yates 1949:32).

The hardware used at the Steiner house is particularly interesting since it is nearly all handmade and reflects the technology of its time. The loop hinge, also sometimes used as a fastener for other hardware, is identical to those used by the Spanish in the 18th century and is found in abundance on both sides of the border (DiPeso 1953:215; Gilmore 1974:76). The butterfly hinge, a style popular in the 17th and 18th century, was generally used on the 1ids of trunks and on cupboard doors (Noel Hume 1969:236). The pintles are identical to those found on sites from the 17th century (Cotter and Hudson 1957:19) to the early 19th century (Kelso 1969; Fig. 11). Simple latching mechanisms such as those represented in this collection had also been in use over a long period and continue in limited use today.

The easily crumbled, sandy mortar found around the chimney at the Steiner house is much like that found in German-made stone structures in the vicinity of San Antonio. The lime for such mortar, fired in local kilns, generally contains small chunks of consolidated 1 ime and fragments of charcoal left in the kiln when the firing process was finished. Family tradition holds that there was a lime kiln on the bank of Coleto Creek near the Steiner place, but no trace of it is visible today. However, it is not unusual for these kilns to be washed away in a major flood such as those which occur often on the coleto. No 1 imestone suitable for burning was observed anywhere in the immediate vicinity.

The Steiner house was built at a time when the manufacturing process for window glass was changing from hand-blown cylinders to cast glass (Roberson 1974:24). The nearly uniform thickness and appearance of the glass recovered suggest that it was made by the latter process, since hand-blown glass tended to vary in thickness. Glass for the windows would have been shipped in via New Orleans and Indianola, packed in boxes of precut panes (ibid.).

Numerous white paint fragments were found in Units $A, B$ and $E$, lying in sheets of layers as if they had been on the surface of boards which rotted away. Upon close examination, the fragments flaked apart to reveal that they were made up of a layer of whiting or gesso with a thin surface coat of gray, covered by a thicker layer of what appeared to be white paint. Early builders' guide books suggested the use of gesso or whiting as a primer or first coat (Crosby 1977: 193). The pigment of a primer was sometimes a light gray made of white lead and lamp black (Kimbro 1968:1). White was the traditional color for houses from the mid 19th century in the United States (Allen 1865:42), and the predominant color used in the Texana area at that time (Crosby 1977:190).

Miscellaneous

Harness buckle with barrel roller, 1-1/2" $\times 1-1 / 4^{\prime \prime}$ (Fig. 37,g).

Heavy hand-forged rod with loop at one end, 5-1/2" overall (Fig. 36,C) 
Unidentified iron object, 2-3/4" $\times 3 / 4^{\prime \prime} \times 1 / 4^{\prime \prime}$ (Fig. 36,d)

Fragments of wire of various sizes

Fragments of barbed wire, single heavy strand, $1 / 8^{\prime \prime}$ diameter, with $1 / 16^{\prime \prime}$ wire barbs twisted $2-1 / 2$ times around at $2-1 / 4$ " intervals

She11, 22 caliber

Lead projectile, 22 caliber

Artificial flower fragments, green and white

\author{
Prehistoric Site \\ Flakes and fragments of chert \\ Chert cores \\ Chert bifacial tool fragment \\ Quartzite grinding tool
}

Flakes and fragments of chert were found on all areas of the Steiner site. Evidence in Unit $A$ at Structure 1 indicated that the deposit was only six inches thick at that location, and no diagnostic artifacts were found which would date the occupation. Numerous other prehistoric sites have been recorded on Coleto Creek, dating from the Paleo-Indian (7000 to 5000 B.C.) through the Late Prehistoric or Neo-American (A.D. 1000 to first European contact) time periods (Fox and Hester 1976). Prehistoric peoples were seeking the same sort of setting for a living site as their historic successors, that is, a dry spot accessible to water and taking the best advantage of breezes and sunshine. Therefore, it is not surprising that historic farm houses were often built over prehistoric camp sites. 


\section{DISCUSSION}

\section{COMPARISON OF STEINER AND SCHOB SITES}

The ceramics on the two sites follow the usual progression found on Texas sites, beginning at the Steiner site with decorated pearlware imported and distributed by merchants throughout south Texas from the time the coastal ports opened in the 1840s until the start of the Civil War. After the war, plain white ironstone was the major type of tableware in use, followed in the early 20 th century by decalcomania-decorated earthenware and plain white earthenware with molded decorations.

The most interesting observation to be made of the ceramics from the complex is the length of time that certain wares were apparently in use, or at least preserved, by the family. Sherds of banded pearlware from the Steiner site are identical to one found at the Schob place, all of which represent small bowls identical to the one still preserved in the family (Fig. 39). . In addition, transfer-printed sherds from both sites are of the same color and pattern. This suggests that dishes acquired by a family before the Civil War were still used by their descendants in the late 19th century and, in some cases, preserved for over 100 years. This would be understandable in the case of the fine, golddecorated porcelain coffeepot which would have been given loving care and probably kept stored in a cabinet. The possibility of the survival of utilitarian, everyday types of ceramics over this long a period has not often been considered by archaeologists when interpreting historic sites. It appears that one should not be too surprised to find occasional sherds of utilitarian pearlware in late 19th and early 20th century farm sites, particularly those once occupied by people of German background.

The glass fragments recovered do not provide any particular information, except that the large number of olive green wine bottle fragments at the Steiner site tends to support his reputation as a winemaker and the supposition that wine was present in some quantity at family meals in the early days. It is interesting to note the presence of molded tumblers at the Steiner site, and the absence of indications of any such vessels at the Schob site. The same holds true of lamp chimneys, which were presumably in use on both sites for nearly their entire period of occupation. The absence of these artifacts at the Schob site suggests that there must have been a trash disposal area somewhere away from the house. Mrs. Augusta Sandhop remembers that, in her childhood, trash was piled behind the guinea house. Superficial examination of this area today yields sherds of late 19th century stoneware crocks and jugs, fragments of ironstone and plain white earthenware with molded designs and milk glass canning jar lid liners, supporting her statement.

By far the most important and useful comparisons can be drawn between the hardware at the two sites. Because of the infrequent preservation in their original state of Texas houses built in the 1850s, little is known of early hardware. Generally when an old house continued in use for a long period of time, the old hardware was replaced with more modern varieties, more ornate and Victorian in appearance. These are attractive and are often copied to be used on restorations of early houses, thus leading to further confusion. At the Steiner site there are indications of the actual types of hardware in use when the house was built: it was hand-wrought (Fig. 38), probably by a local blacksmith, and not very 


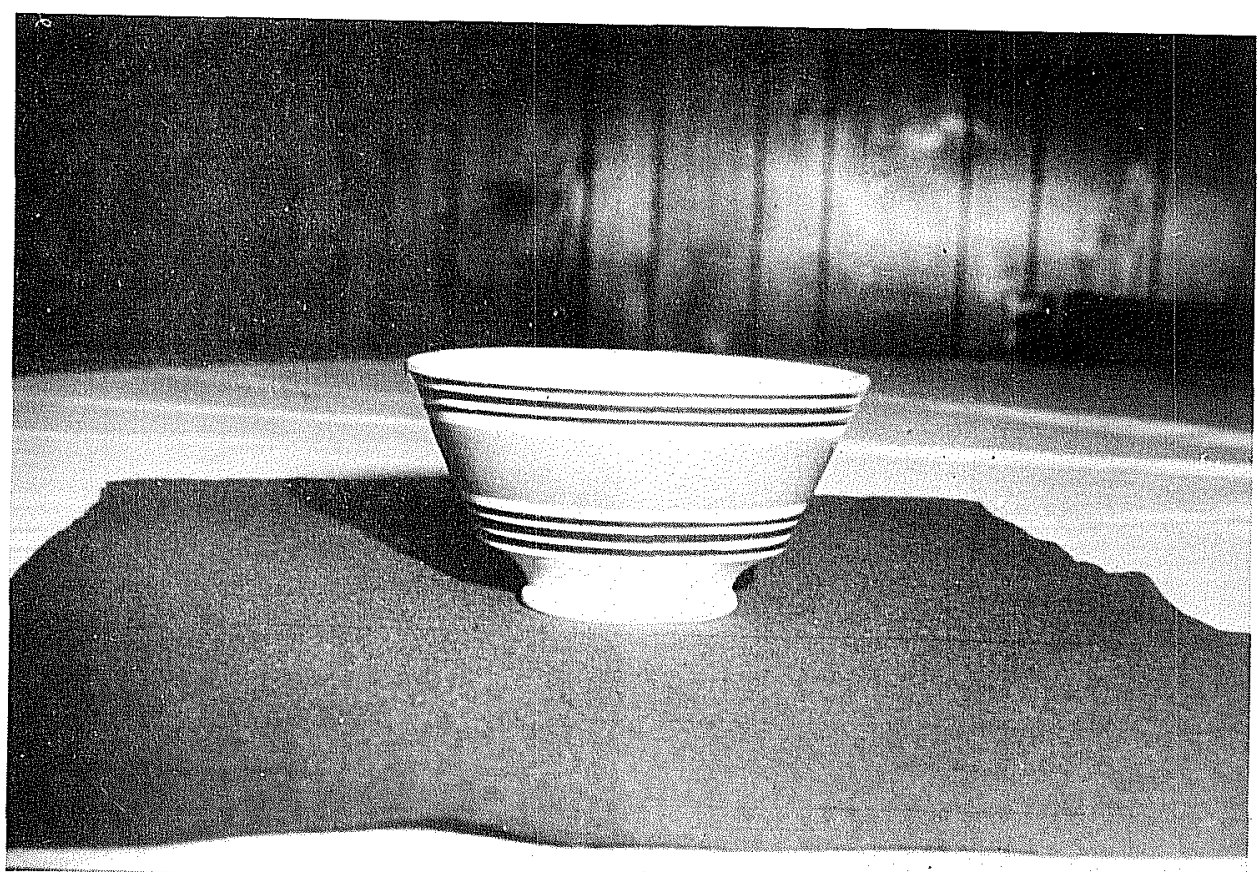

a

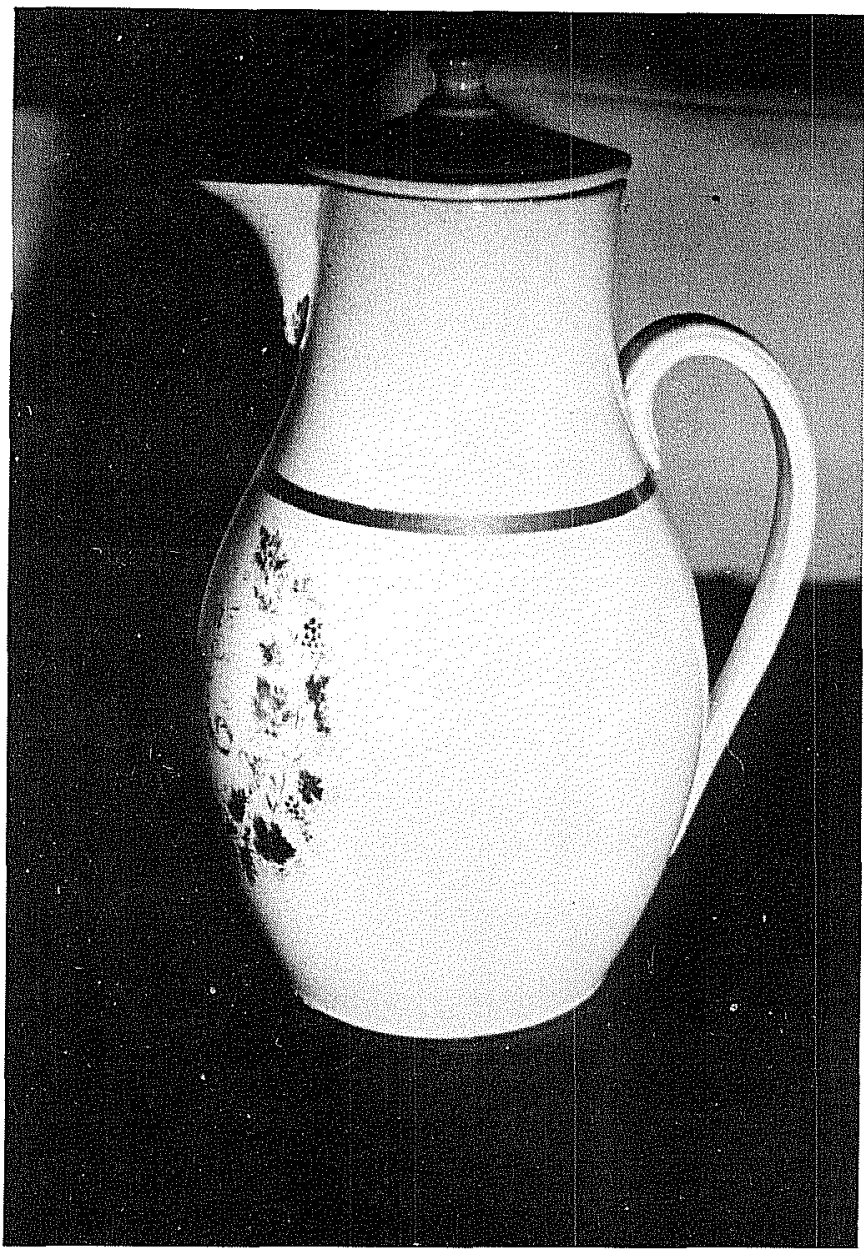

b

Figure 39. Ceramic Vessels still in Steiner Family. a, banded ware bow 1 used by Mrs. Schob to hold butter--diameter 5 inches, height 4 inches. Mrs. Augusta Sandhop; b, porcelain coffeepot with gold decoration, marked "Victoria Steiner"-height $9-1 / 2$ inches. Mrs. W. C. Johns. 
TABLE 3. U.S. CENSUS DATA

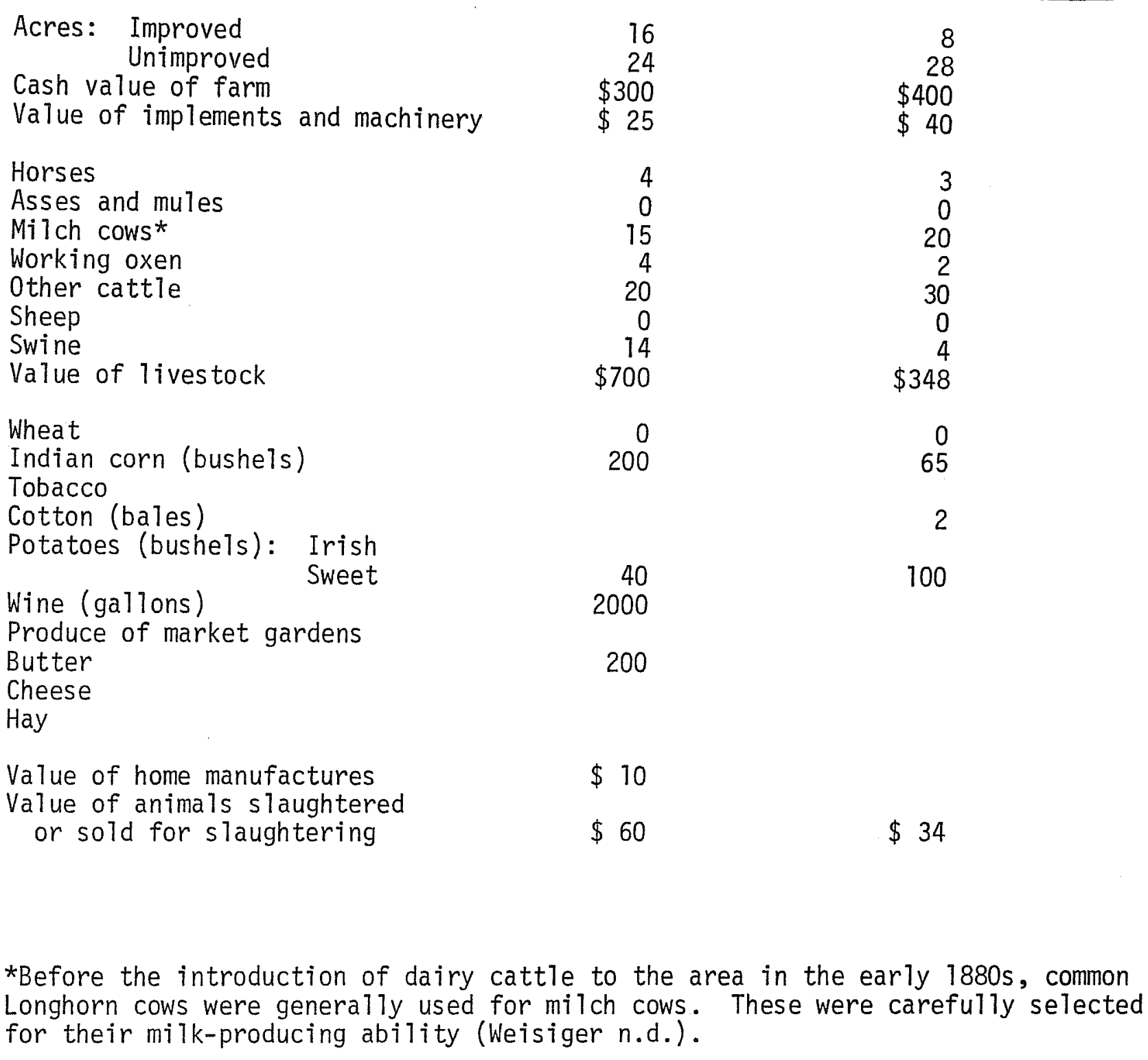

$1860 \quad 1870$

C. Steiner Friedrich Schob de Leon

$\$ 10$

$\$ 60 \quad \$ 34$

*Before the introduction of dairy cattle to the area in the early 1880s, common for their milk-producing ability (Weisiger n.d.). 
different from that in use over the previous 200 years. The design was simple and functional. A contrast is provided by the more ornate hardware at the Schob house, most of which reflects its late 19 th century origins. The hasp on the kitchen door (Fig. 13, C) and the interior door locks (Fig. 12,d) are similar to those offered by Montgomery Ward and Company in their 1895 catalog (1969:373). The ornate hand-forged lock on the front door (Fig. 12,a,b) is said to have been imported from Germany (Mrs. Johns, personal communication). A similar lock is on display in the Sophienburg Museum in New Braunfels. These locks may have been imported for use in the late 19th century homes of the German Texans.

The Steiner house was built with cut and wrought nails, as might have been expected in the 1850s. Mr. Schob also built his house using cut nails, but later repairs and additions were done with wire nails, which became available by the Tate T880s (Nelson 1968).

Any sort of numerical, quantitative comparison of artifacts from the two sites would not appear to serve any particular purpose. The sampling was not sufficiently extensive to give what the author would consider a fair overview of the site contents, and the artifacts recovered should be treated merely as an interesting cross section of what is probably present. In dealing with artifactual evidence beneath and around an historic site, a number of factors make it impossible to venture more than an educated guess about the complete assortment of objects used, broken, lost or discarded at the site. One of the leastunderstood factors at the present time, and one of the most important in terms of artifactual analysis, is the attitude of the residents toward rubbish disposal. Deetz (1977:125) has made some observations on this problem for New England historic sites, where the people have an English background and English customs to follow. South (1977:47-80), working also with former Englishmen, goes at it in a slightly different way, tracing patterns of refuse disposal. Both deal primarily with the 17th and 18th centuries. The same sorts of careful observation must be made about 19th century Texas sites of various backgrounds, including Anglo-American, German, Mexican, Slavic and Negro, to name a few of those present in south Texas. The author has already done some preliminary work along these Tines in Spanish sites of the 18th century in San Antonio (Fox, Bass and Hester 1976; Fox 1977).

Investigations at the Steiner site did not reveal any significant data on which to judge what method of trash disposal was used. No garbage pits or trash piles were located, al though the thin scattering of surface artifactual material suggests that there should have been such a concentration somewhere. The problem is not unique to this site, or even to other Texas sites (Carter and Ragsdale 1976:35). Deetz (1977:14) has remarked on a similar dearth of artifacts on early New England sites and suggests that it is due to a "short supply of essential goods." It would be easy to shrug off the situation for this reason, or to blame it on poverty or German frugality, but in a given number of years of 1iving, a given amount of trash is bound to be produced, be it chert flakes and tools, broken dishes and bottles, or tin cans and plastic containers. Until more attention is given to this problem, historical archaeology will continue to record a most fragmentary picture of the total artifactual evidence on each site.

The location and excavation of trash deposits must become a routine part of historic site excavations, rather than an accident of archaeological sampling, before the total picture of each site can be recovered. Such an effort wi11 
necessitate more extensive examination of both the historical record and the actual site, including sophisticated survey techniques such as extensive phosphate testing (see Appendix I) and other methods of surface examination for detection of subsurface remains.

\section{CENSUS REPORTS}

Census reports are an invaluable resource, both for the historian and the historical archaeologist, as an aid to understanding and interpreting a site. Where archaeology shows by the faunal remains recovered that a family was consuming pork and chicken, the census report can tell whether they were raising them on the farm or purchasing them elsewhere. Where the archaeological excavations produce evidence for milk processing and consumption, the census report tells how many cows were kept, what percentage of their livestock this represents, and whether the family was selling the by-products. The census reports also explain puzzling facts which archaeological excavations recover and might misinterpret, such as the number of wine bottles present at the Steiner site.

Table 3 contains information extracted from the U.S. Census Agricultural Tables for the year 1860, when Mr. Steiner was in charge of the farm, and for 1870, when his son-in-law had taken it over. Whether as a result of the disruptions of the Civil War or as a reflection of the policies of the new owner, a number of basic changes had taken place over the 10-year period.

The amount of land involved is substantially the same, subtracting the four acres $\mathrm{Mr}$. Schob sold to his neighbor, Mr. Kobitz, in 1869. Apparently some of the "improved" land was returned to pasture, perhaps during the war when Mr. Schob was gone and help was short. Cash values of land and farm implements had risen in equal proportions.

Changes in livestock are interesting to observe. The numbers of animals in proportion to acreage owned seem high, until one realizes that this was before the days of barbed-wire fences. Livestock were allowed to run wild most of the time, foraging for themselves. They were marked or branded and rounded up when necessary (Jordan 1966:85-89). Work animals were horses and oxen. For bringing the land into shape for cultivation, Mr. Steiner had two yoke of oxen, the animals best suited to the heavy work of pulling stumps and breaking up the soi1 (Sitterson 1953:51). By 1870, perhaps because they were no 1onger needed for such heavy work, only one yoke of oxen was kept. Where Mr. Steiner had a diversified farm operation producing a variety of crops in 1860 , by 1870 cattle were beginning to be the dominant occupation of the farm. By 1870 the actual value of livestock had sunk to half what it was in 1860, despite the increase in number of cattle on the place.

Indian corn and sweet potatoes were the staples of the average Texas family's diet before the 1880s, and the German immigrants quickly adapted to this diet despite the fact that the majority of them were more accustomed to wheat and white potatoes. According to the average yield published for Victoria County in The Texas Almanac of 1867 (168). Mr. Steiner would have had six to seven acres planted in Indian corn in order to obtain 200 bushels. Evidently $\mathrm{Mr}$. Schob found it more profitable to raise sweet potatoes. It also may be that the lower number of acres considered "improved" reflects this change in emphasis, as only two acres would have been required to raise 65 bushels of corn. 
At the same time, approximately two additional acres would have been required to produce the two bales of cotton Mr. Schob reported (ibid.). German Texans were known for their superior cotton, which brought premium prices in the market because of their care and cleanliness in picking (Benjamin 1974:72).

Milk cows were important to the early settlers, both Germans and Anglo-Americans, as milk and milk products were considered a necessity in their diet. The calves were kept penned up near the house, while the cows grazed freely during the day, returning each evening to their calves in the farmyard (Jordan 1966:91). In $1860 \mathrm{Mr}$. Steiner and his immediate neighbors, Kobitz and Schubert, each reported making 100 or more pounds of butter (U.S. Census 1860). This butter was probably traded or sold in Victoria, as German farmers in south Texas often sold butter to the citizens of neighboring towns (Jordan 1966:91). It is interesting to speculate what was being done with the milk from the 20 cows kept by $\mathrm{Mr}$. Schob, when $\mathrm{Mr}$. Steiner had been making 200 pounds of butter from five fewer cows, 10 years previously.

One of the most interesting items found in the census reports is the 2000 gallons of wine made by the Steiners in 1860 . This was probably made both from cultivated grapes and from the wild mustang grapes found in great abundance throughout the area. Family tradition says there was an unsuccessful attempt at raising grapevines in a field just north of the Schob house (Mrs. Johns, personal communication), but beyond that there is no information available about winemaking activities in the family. However, the German farmers on Coleto Creek were known statewide for their winemaking (Thurmond 1867:111).

Because of the acidity of the mustang grape, large quantities of sugar would have been required. The possible source of this sugar was not too far away. Anglo-American settlers began experimenting with raising sugar cane soon after their arrival in Texas. By 1830 there were several sugar mills in operation in east Texas (Sitterson 1953:41), and by 1852 Texas had 15 horse-powered mi $11 \mathrm{~s}$ and 29 steam mills (ibid.:43). In 1845 John S. Menefee had a sugar mill near Texana on the Navidad River, about 30 miles from Coleto Creek, and Brazoria was a sugar-producing center in the 1850 s and 1860 s (Martha Freeman, personal communication).

It would be interesting to know why in 1870 neither $\mathrm{Mr}$. Schob nor any of his neighbors was making wine. Some were still marketing butter. Nearly everyone was producing a few bales of cotton at this time, and a few were raising Irish potatoes (U.S. Census 1870). At the Steiner-Schob farm, the diversification of $\mathrm{Mr}$. Steiner was changing to a simpler economy based on cattle, sweet potatoes and corn, with a cash crop of cotton.

\section{COMPARISON WITH OTHER SITES}

The structures investigated at LBJ State Park (Tunnel? and Jensen 1969) include both $\log$ and stone buildings built just before and after the Civil War, and the artifacts recovered reflect that time period. The houses were supported by continuous stone foundations set directly on the ground, as was the Steiner house foundation. Many of the farm buildings were built of cut limestone, reflecting the abundant natural supply of limestone in the area. The only site on which handpainted earthenware sherds were found was built in 1860, just prior to the 
Civil War. However, transfer, banded and edged wares were found on a site thought to date from ca. 1869. This could represent the same sort of careful husbanding of ceramics noted in the Steiner-Schob family, or perhaps German frugality and conservatism in retaining articles which would have been discarded by Anglo-American farmers.

Excavations at the Biegel settlement (Carter and Ragsdale 1976) included three sites settled in the 1850s by Germans who adopted Anglo-American settlement patterns (ibid.:115). Features noted there which correspond to those found at the Steiner-Schob complex include dovetail corner notching, multiple reuse of timbers and reuse and remodeling of structures. The same pattern of thin deposits of early artifacts was noted on these sites as at the Steiner place. For example, from the Polasek house site where the majority of the excavation was done, only 10 ceramic sherds were recovered which could positively be representative of the 1850-1860 time period, although there was such an abundance of artifacts from later periods on the house site that only a representative sample was collected (Carter and Ragsdale 1976:43).

In a number of ways, the LBJ Park settlement more closely resembles the SteinerSchob complex than does the Biegel settlement. There are a number of factors which could account for this similarity. Both the LBJ Park and the SteinerSchob settlements were relatively isolated from influences of other ethnic groups for the generations during which the primary construction was taking place. The Biegel settlement was peopled by "an international group" (ibid.:78), which undoubtedly influenced the culture of the residents. Also, the availability of building stone--limestone in the Hill Country and sandstone on Coleto Creek-probably had an important influence on the architectural styles chosen.

With the exception of a few homesites of Mexican settlers of the DeLeon Colony, all historic sites within the Palmetto Bend and Cuero Reservoir surveys were Anglo-American, occupied from the 1830s to the 20th century. The artifacts recovered were collected from the surface or from minimal testing and could not be considered a quantitative sample. However, the assortment is nearly identical to that found at the Steiner-Schob complex, demonstrating that the types of artifacts present in 19th century sites in south Texas provide little indication as to the nationality of the residents. This is further borne out by the absence of Mexican ceramics on sites settled by DeLeon Colony people (Mallouf, Fox and Briggs 1973:193), all of which contained imported English wares typical of preCivil War period Anglo and German sites. A house site on one of the DeLeon family grants north of Victoria also contains primarily English ceramics. The presence on this site of a sherd of late Mexican majolica, however, betrays the ethnic background of the inhabitants. 


\section{SUMMARY AND CONCLUSIONS}

Archaeological and architectural investigations at the Steiner-Schob complex have produced a great deal of information about the 1 ife of a German immigrant family on Coleto Creek between 1850 and 1920. It is possible, through examination and comparison of the two sites, to observe the gradual changes as the family progressed from their first smail farmhouse to a large, impressive stone house, indicative of a secure and prosperous life and status within the community. We can follow their progress from the time when roads were bad or nonexistent and most travel was on foot (Mrs. Johns, personal communication; see also Carter and Ragsdale 1976:92) to their acquisition of a Model T Ford and the arrival of the modern era of transportation. Observations are possible of the changes in technology between the locally-made objects of pre-Civil War times and the industrialization represented by the mail order catalog and mass production. We can also observe the evolution in farming practices as intensive, diversified farming gradually moved toward stock raising as practiced in the area today.

No pattern of structures or artifacts was found at the Steiner site which would lead one to believe that this was a German rather than an Anglo-American family, except the scarcity of artifacts present on the surface, and possibly the care in conservation of ceramics over a longer period of time than usual. South (1977:77) has suggested that the Germans on the East Coast were "inordinately neat" compared with their neighbors, and that this type of observation may be a clue for identification of a German site. Judging from artifact recovery at the Biegel and LBJ Park sites, this could be true, but a great deal more work in early Texas sites will be necessary to confirm it.

The Steiner-Schob complex in some ways bears out Jordan's (1966:199-200) hypothesis of "cultural rebound," in which he suggests that the German immigrants were quick to adopt the architecture of the Anglo-American settlers when they first arrived, but as soon as possible tended to return to their traditional types of construction. The Schob house is an excellent example of this sort of rebound, as it was undoubtedly Mr. Schob's attempt to bulld the sort of home he had dreamed of having since he left Germany thirty years before. The Kobitz house nearby, a frame Victorian house built in 1873, fits Jordan's (ibid.:167) theory that by 1880 or 1890 "the Germans abandoned stone construction and began building frame houses devoid of any trace of imported methods, thus completing this aspect of their assimilation." The fact that this was the second generation in the Kobitz family in Texas undoubtedly was also a factor in the choice of style.

Jordan's (1966:192-198) observations on acculturation of the German settlers as a whole appear to be accurate for the Coleto settlement. While farms outwardly resembled Anglo-American farms, there was greater intensity and diversity, and better productivity--a more intimate understanding and attachment to the soil.

Not reflected in the archaeological record is the social distinctiveness of the German community. German was the only language spoken in the home throughout the Schobs' lifetime (Mrs. Sandhop, personal communication); the singing and shooting societies were the center of social life (Eichholz 1883:85); and music was important in the family (see pp. 7,19, Fig. 40) and in the community as a whole (Weisiger $n_{0} d_{0}: 68$ ). 


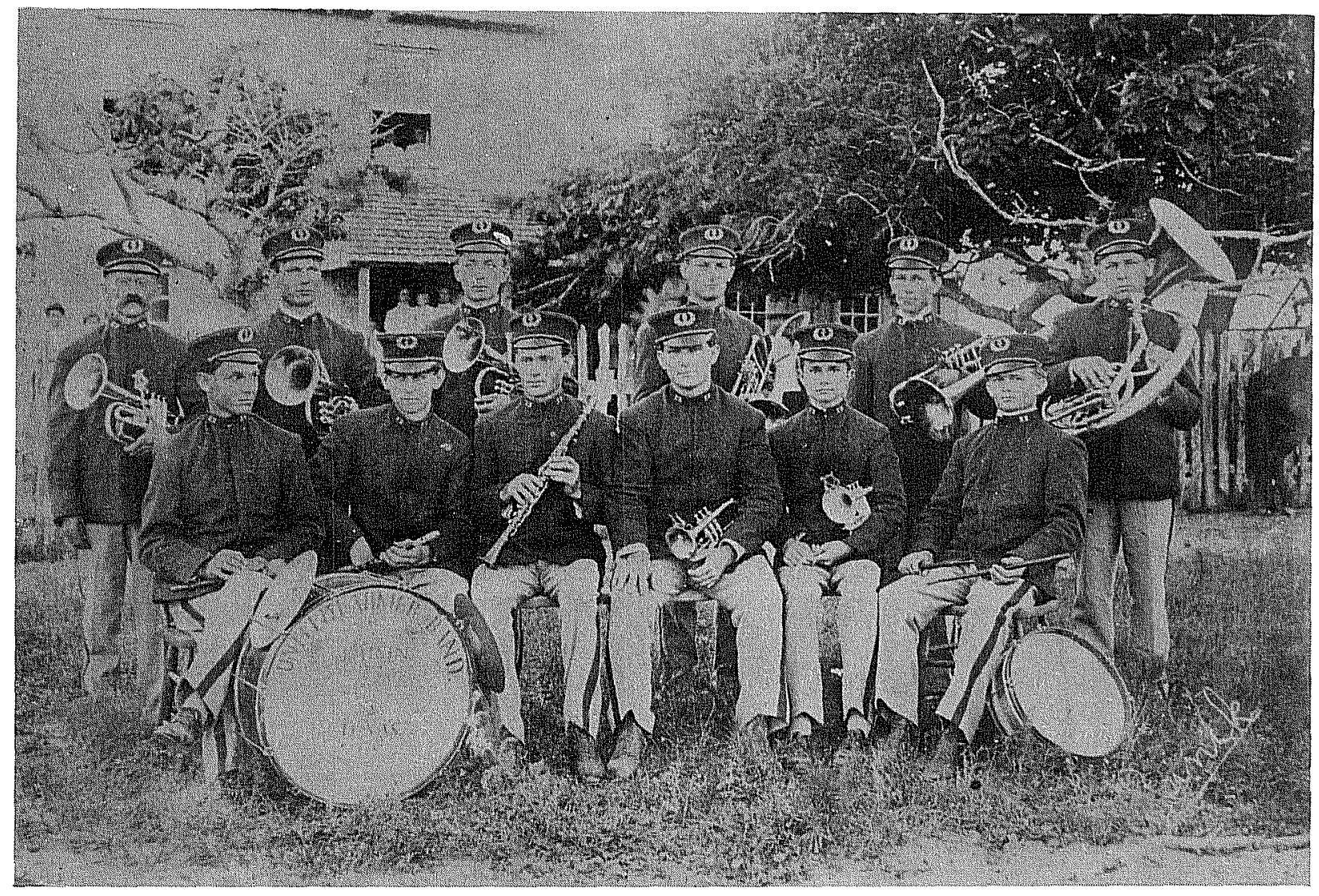

Figure 40. Raisin Band, ca. 1905. Posed in front of Schob House. Left to right, standing--William Hohman, Richard Pantel, Theodore Willemin, Frank Horadam, Fred Maurer, Adolph Horadam. Seated--E. G. Schubert, Edwin Schubert, Herman Schubert, Victor Horadam, Ewald Hohman, Eddie Schmidt (Morris 1953). 
In conclusion, the Steiner-Schob investigations produced evidence that the German immigrants in south Texas, as elsewhere in the state, tended to adopt the local building and farming practices of their Anglo-American neighbors, but retained their German tendency toward frugality and conservatism. "The result was a blend of adopted and imported traits, a partial assimilation, which caused the Texas Germans to differ not only from southern Anglo-American farmers, but also from their countrymen back in Europe" (Jordan 1966:192). 


\section{REFERENCES CITED}

Adams, J. P.

1971 Bottle Collecting in America. New Hampshire Publishing Company, Somerworth.

Alexander, D. B.

1966 Texas Homes of the Nineteenth Century. University of Texas Press, Austin.

Allen, L. F.

1865 Rural Architecture. Orange Judd and Company, New York.

Baldwin, J. K.

1973 A Collector's Guide to Patent and Proprietary Medicine Bottles of the Nineteenth Century. Thomas Nelson, Inc., Nashville and New York.

Benjamin, G. G.

1974 The Germans in Texas, A Study in Immigration. Jenkins Press, Austin.

Biesele, R. L.

1930 The History of the German Settlements in Texas 1831-1861. Von Boeckmann-Jones, Austin.

Brinckerhoff, S. B.

1965 Metal Uniform Insignia of the U.S. Army in the Southwest, 18461902. The Journal of Arizona History, Summer.

Brown, W. H.

1864 Topographical Map of the Country Between San Antonio and Colorado Rivers in the State of Texas. By order of Captain Tipton Walker, Chief of (Topographical) Bureau. National Archives, RG 77(249):3.

Carter, E. S. and C. S. Ragsdale

1976 Biegel Settlement: Historic Sites Research, Fayette Power Project, Fayette County, Texas. Texas Archeological Survey, Research Report 59. 
Castañeda, C. E.

1936 The Mission Era, the Winning of Texas 1693-1731. Our Catholic Heritage in Texas II. Von Boeckmann-Jones Company, Austin.

Cotter, J. L. and J. P. Hudson

1957 New Discoveries at Jamestown. National Park Service, United States Department of the Interior, Washington, D.C.

Crosby, H. A.

1977 Architecture of Texana, 1831-1883, Jackson County, Texas. Texas Archeological Survey, Research Report 57, Palmetto Bend Reservoir Series 2.

de Cordova, J.

1969 Texas: Her Resources and Her Public Men. First printed 1858. Reprinted by Texian Press, Waco.

Deetz, J.

1977 In Small Things Forgotten. Anchor Books, Doubleday, New York. DiPeso, C. C.

1953 The Sobaipuri Indians of the Upper San Pedro River Valley, Southeastern Arizona. The Amerind Foundation Publications 6. Dragoon, Arizona.

Durrenberger, E. P.

1965 Anderson's Mi11 (41 TV 130): A Historic Site in Travis County, Texas. Bulletin of the Texas Archeological Society 36:1-70.

Eichholz, W. T.

1883 Die deutschen Ansiedlungen am Colletto. Schütze's Jahrbuch für Texas und Emigrantenführer für 1884. A. Schütze, Austin.

Fontana, B. L. and J. C. Greenleaf

1962 Johnny Ward's Ranch: A Study in Historic Archaeology. The Kiva 28:1-2.

Fox, A. A.

1977 The Archaeology and History of the Spanish Governor's Palace Park. Center for Archaeological Research. The University of Texas at San Antonio, Archaeological Survey Report 31. 
Fox, A. A. and T. R. Hester

1976 An Archaeological Survey of Coleto Creek, Victoria and Goliad Counties, Texas. Center for Archaeological Research. The university of Texas at San Antonio, Archaeological Survey Report 18.

Fox, A. A., F. Bass, Jr., and T. R. Hester

1976 The Archaeology and History of Alamo Plaza. Center for Archaeological Research. The University of Texas at San Antonio, Archaeological Survey Report 16.

Fox, D. E., R. J. Mallouf, N. O'Malley and W. M. Sorrow

1974 Archeological Resources of the Proposed Cuero I Reservoir, DeWitt and Gonzales Counties, Texas. Texas Historical Commission and Texas Water Development Board, Archeological Survey Report 12.

Fretelliere, $A$.

1934 Adventures of a Castrovillian. In: Castro-Ville and Henry CastroEmpressario, by Julia Nott Waugh: 80-96. Standard Printing Company, San Antonio.

Gilmore, K.

1974 Mission Rosario, Archeological Investigations 1973. Texas Parks and Wildife Department, Historic Sites and Restoration Branch, Archeological Report 14:1.

Illinois Glass Company

1903 Illustrated Catalogue and Price List. Alton, I11inois. Jordan, T. G.

1966 German Seed in Texas Soil, Immigrant Farmers in Nineteenth Century Texas. The University of Texas Press, Austin.

1972 Some Comments on Log Construction in Texas. The Architecture of the Texas Frontier. A Series of Papers Delivered at the 1972 Winedale Warkshop:59-76. The Texas Historical Survey Committee and The University of Texas at Austin-Winedale Inn Properties.

Kelso, W. M.

1969 Historical Archaeology in Georgia, 1968: Two Nineteenth Century Sites. The Conference on Historic Site Archaeology Papers 1969, $4: 16-25$. 
Kendrick, $G$.

1963 The Antique Bottle Collector. Edwards Brothers, Ann Arbor, Michigan.

Kimbro, T.

1968 Paint Analysis. Winedale Workshop I. A Conference on the Principles of Architectural Preservation and Restoration, September 13-14, 1968. Winedale Inn Properties and The Texas State Historical Survey Committee.

Linn, J.

1883 Reminiscences of Fifty Years in Texas. D. and J. Sadler, New York.

Lorrain, D.

1968 An Archaeologist's Guide to Nineteenth Century American Glass. Historical Archaeology 2:35-44.

Mallouf, R. J., D. E. Fox and A. K. Briggs

1973 An Assessment of the Cultural Resources of Palmetto Bend Reservoir, Jackson County, Texas. Texas Historical Commission and Texas water Development Board, Archeological Survey Report 11.

McClinton, K. M.

1951 Antique Collecting for Everyone. Bonanza Books, New York.

McKearin, G. S. and H. McKearin

1941 American Glass. Crown Publishers, New York.

Montgomery Ward and Company

1969 Catalogue No. 57, Spring and Summer, 1895. Dover Publications, Inc., New York.

Morris, L.

1953 Pictorial History of Victoria and Victoria County. Clemens Printing Company, San Antonio.

Nelson, L. H.

1968 Nai1 Chronology As An Aid to Dating 01d Buildings. American Association for State and Local History Technical Leaflet 43. 
Nö̈1 Hume, I.

1969 Historical Archaeology. Knopf, New York.

1970 A Guide to Artifacts of Colonial America. Knopf, New York.

O'Connor, K. S.

1966 The Presidio La Bahia del Espiritu Santo de Zuniga, 1721-1846. Von Boeckmann-Jones Company, Austin.

Roberson, W. R.

1974 The Carrington-Covert House, Archeological Investigation of a 19th Century Residence in Austin, Texas. Texas Historical Commission, office of the State Archeologist, Report 25.

Roemer, F.

1935 Texas. Standard Printing Company, San Antonio.

Rose, V. M.

1883 Some Historical Facts in Regard to the Settlement of Victoria, Texas. Daily Times Print.

Schmidt, C. F., Translator

1931 Texas in 1848 by Victor Bracht. Naylor Company, San Antonio.

Sears, Roebuck and Company

19681897 Sears Roebuck Catalogue. Chelsea House, New York.

Self, A.

1950 Schob House is Memorial to German Immigrant's Labors. The Victoria Advocate, July 9.

Sitterson, J. C.

1953 Sugar Country, The Cane Sugar Industry in the South, 1753-1950. University of Kentucky Press.

Sloane, E.

1967 An Age of Barns. Ballantine Books, New York.

South, S.

1977 Method and Theory in Historical Archeology. Academic Press, New York. 
Switzer, R. R.

1974 The Bertrand Bottles: A Study of 19th Century Glass and Ceramic Containers. National Park Service, United States Department of the Interior, Publications in Archeology 12. Washington, D.C.

The Texas Almanac

1867 The Texas Almanac for 1867. Richardson Publishing Company, Galveston.

Thurmond, A. S.

1867 Goliad County. In: The Texas Almanac for 1867. Richardson Publishing Company, Galveston.

Tunne11, C. D. and H. P. Jenson, Jr.

1969 Archeological Excavations in Lyndon B. Johnson State Park, Summer, 1968. State Building Commission Archeological Program 17.

United States Census Office

1850- Seventh Census, 1850; Eighth Census, 1860. Government Printing 1860 Office, Washington, D.C.

Victoria County Records

Abstract Records 5:18.

Naturalization Records.

Probate Records.

Victoria Sesquicentennial, Inc.

1974 The Victoria Sesquicentennial "Scrapbook" 1824-1974. Advocate Printing, Inc., Victoria.

Vinton, D. H.

1858 Unpublished diary of Major D. H. Vinton. Copy in A. Fox's possession.

Walsh, W. C.

1879 Map of Victoria County. August Gast and Company, St. Louis (copy in the General Land Office, Austin).

Weisiger, S. R.

n.d. Life Along the Coleto. Vignettes of Oed Victoria (scrapbook of undated newspaper columns from The Victoria Advacate). Victoria Public Library. 
Wiggington, E., Editor

1972 The Foxfire Book. Doubleday, New York.

Yates, R. F. and M. W. Yates

1949 A Guide to Victorian Antiques. Gramercy Publishing Company, New York.

Yount, J. T.

1967 Bottle Collector's Handbook and Pricing Guide. Action Printery, San Angelo. 


\section{APPENDIX I: SOIL ANALYSIS}

Thomas W. Medi in

Chemical analysis of soils to determine phosphate content was carried out at 41 VT 62. The purposes of the analysis were to determine applicability of phosphate testing as a method of field site surveying to locate areas of possible interest within a site and also to determine its feasibility for future use.

It is known that human and animal habitation contributes considerable amounts of chemicals to the soil. These are added mainly through excrement and carrion. Of these chemical additions, phosphate is the only one not severely affected by natural leaching of soils. The phosphates left by human and animal habitation rema in in the soil where they were deposited with little or no horizontal migration and remain relatively stable over archaeological time.

The testing was done using a field method discussed by Robert C. Eidt (1973:206210) and previously tested by Elaine Burleigh (1974). The method is simple and designed to be done in the field. It takes a small amount of equipment and is inexpensive and easily done.

The field kit consists of a ring stand, two $100 \mathrm{cc}$ plastic bottles with droppers or eye droppers, and an adequate supply of No. 42 ashfree filter papers. The chemical requirements are $5 \mathrm{~N}$ hydrochloric acid, chemically pure ammonium molybdate, chemically pure ascorbic acid and distilled water.

Two chemical reagents are needed. Reagent $A$ is $30 \mathrm{ml}$ of $5 \mathrm{~N} \mathrm{HCl}$ to 5 grams of ammonium molybdate dissolved in $100 \mathrm{ml}$ of cold distilled water. Reagent $B$ is 1 gram of ascorbic acid in $200 \mathrm{ml}$ of distilled water. Reagent $A$ is used in the extraction of phosphate and Reagent $B$ is used as a reduction agent. Reagent $A$ may be used for a time period of about a month; however, Reagent $B$ holds its effectiveness for only a day so that it is necessary to prepare a fresh batch daily. Premeasured amounts of all chemicals should be taken to the field so that fresh reagents can be prepared as needed.

Care should be taken to prevent contamination of equipment and soil samples. Equipment should be washed in a solution of $5 \mathrm{~N} \mathrm{HCl}$ and distilled water before being used. Soil samples should not be touched by the hands. Avoid letting droppers come in contact with soil samples during testing.

The soil sample needed for testing is $50 \mathrm{mg}$, or about the amount that can be placed on the tip of a clean, sharp, pointed knife. There does not seem to be any reason to get the amount exact, and the size can be estimated with fair accuracy.

A filter paper is placed on the ring stand and the soil sample is placed in the center. Exact7y 2 drops of Reagent A are added to the sample, followed by 2 drops of Reagent $B 30$ seconds later. Blue radiating lines will appear and form a circle around the sample. This blue coloration indicates the presence of phosphate and is used to rate the strength of the phosphate in the sample. Strength ratings should be done 2 minutes after Reagent $B$ is added. The 2-minute point seems to be the maximum point of effectiveness. After the samples have set for 10 minutes, all samples will appear about the same, regardless of strength. 


\section{FIELD PROCEDURE}

Testing was done using grid lines extended from the site grid (Fig. 41). The northeast corner of the 32-foot-square grid of Structure 1 was designated NOEO and used as the center point of our testing grid. Four lines were extended from NOEO past the known 7 imits of the site proper. The north-south line ran along the east edge of the Structure $1 \mathrm{grid}$, and the east-west line ran along the north edge of the Structure 1 grid. The west 1 ine extends 64 feet from NOEO. At 32 feet an additional 7 ine was taken north for 24 feet to Structure 2 and then west to 104 feet from the north-south line (N24W704) (see Fig. 41). This was done to enable us to take samples from all three known structures.

Soil samples were taken every 8 feet along these grid lines. Samples were taken by digging a hole with a post hole auger and cleaning off one face with a clean trowel. A sample was then removed from the cleaned face with a spoon. The samples were large enough to allow for several tests each if needed.

In the area of Structure 1 and between Structure 1 and the cemetery, on the east test line, the soil is a dark brown humus sandy loam underlain by a red clay. The soil here is only 1 to 2 inches in depth. The soil along the south and west lines, away from the immediate area of Structure 7 , is a dark brown humus sandy loam with red clay, more than 7 foot deep. Along the north 7 ine, which extends into a cleared field, the soil is a light tan sandy loam. The depth to the clay here is unknown.

In the areas where the top soil was only 1 to 2 inches in depth, samples were taken at the contact zone of the soil and clay. In other areas with deeper top soil, samples were taken at approximately 4 to 5 inches in depth. Each sample was placed in a plastic bag and labelled with the grid coordinates.

Samples were also taken at the nearby site 41 VT 61, which dates to a later time period. Four samples were taken in the area of the old privy. Two samples were taken in the modern barnyard, and one was taken at the location of a witnessed bovine urination. The last sample was used as a known high phosphate content control sample.

Due to the lack of field time and the purpose of the testing, the soil samples were analyzed in the lab using the field procedure.

Eidt (1973) set three criteria for the determination of strength: length of radiating lines, time of appearance of lines and percent of ring around the sample. It quickly became apparent that these criteria were not usable in our test. When the reagents were added to the samples, light-weight organic matter was carried outward far more than was desirable. It was therefore decided to use a color rating, judging strength by color intensity. Ten samples were tested to determine criteria for rating.

Five strength ratings were given to samples tested: None, Very Weak, Weak, Medium and High. Samples were tested out of order, in a random manner, so as to avoid biasing the judgment of ratings. Each sample was recorded as to test number, coordinate and strength rating. The filter paper of each test had test number and strength rating labelled on it for back reference. All questionable tests were run a second time to insure proper rating. Final results were not studied until after a 11 tests were completed. 


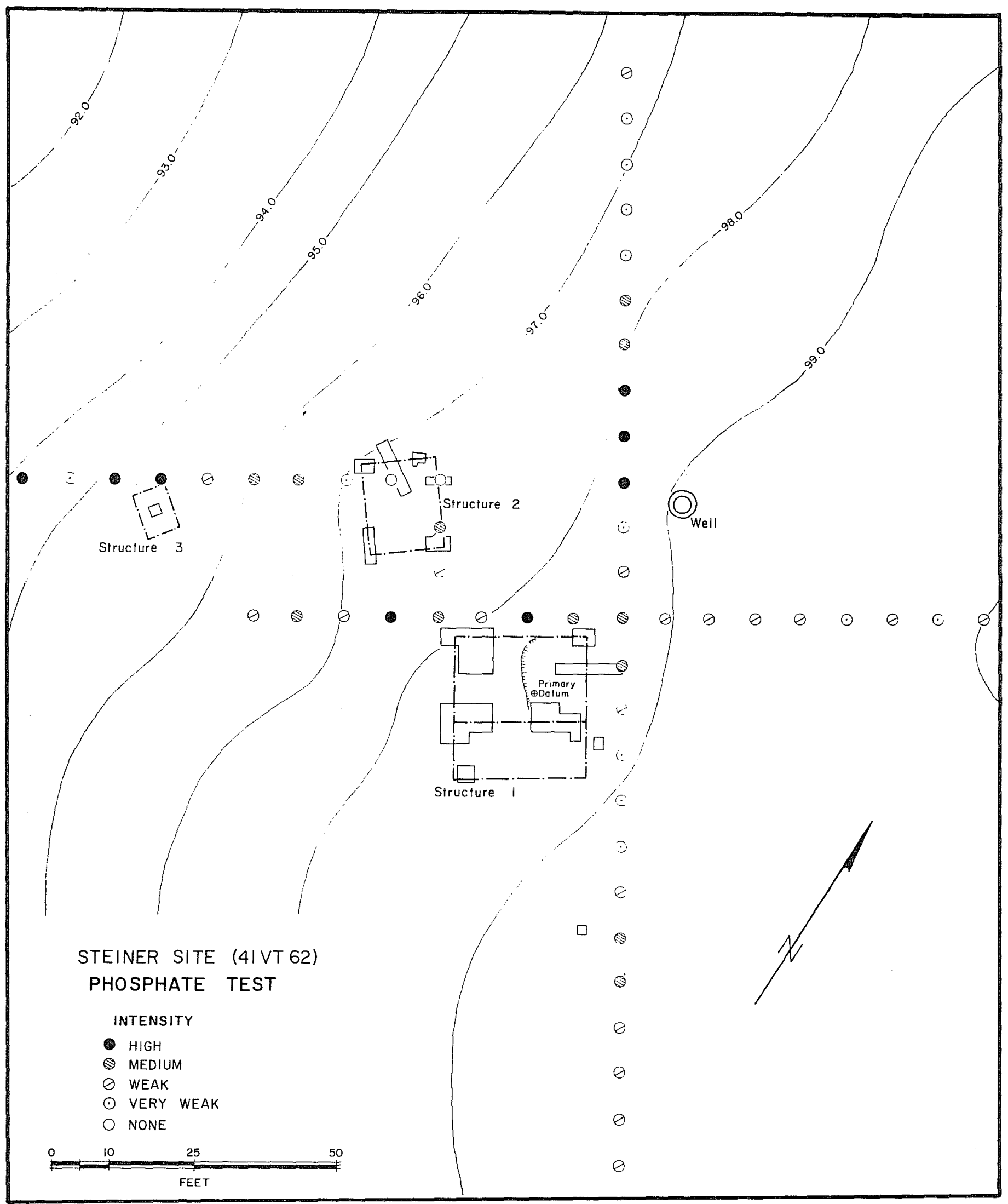

Figure 41. Steiner Site (41 VT 62), Phosphate Test. 


\section{RESULTS}

A map was made of the site showing the three known structures, the well and the testing grid. Test strengths were plotted on the map. In this manner the location of each test could be seen in relation to the various features of the site (Fig. 41).

The test results are very satisfactory. The High and Medium ratings are predominantly in areas of suspected high use. The tests outside the site proper show mostly Weak and Very Weak strength ratings. The areas near the well and Structure 3 show High ratings. It was expected to find high phosphate content near the well, due to the usual gathering of animals near a watering place. Structure 3 is the farthest known feature from the main living quarters (Structure 1). Structure $3^{\prime}$ 's function is not known, but could easily have served as a location for animal care or butchering or human defecation.

Structure 2 appears to have been filled with soil from a different location after abandonment. The two tests from this feature with a "None" rating were taken from this fill. The erratic ratings around Structure 1 could possibly be due to the extremely shallow soil in this area.

A1l tests taken from 41 VT 61 had high strength ratings as expected; this area is still used as a barnyard.

\section{CONCLUSIONS}

The test results have shown this method of phosphate detection to be a useful field tool for the location of features of possible interest. This field method can give immediate results which, when properly interpreted, can give valuable information on areas to be excavated or explored.

It is suggested, however, that this method be tested many times with field application. Further study is needed to help eliminate the errors inherent in this type of subjective testing. 
Burleigh, E.

1974 Texas Archeological Society, An Experiment in Historical Archeology. In: Archeological Investigations at the Thomas F. McKinney Homestead, Travis County, Texas (M. McEachern and R. W. Ralph). Unpublished.

Eidt, R. C.

1973 A Rapid Chemical Field Test for Archaeological Site Surveying. American Antiquity 38(2):206-210. 
APPENDIX II

ARCHITECTURAL DRAWINGS OF FRIEDRICH SCHOB HOUSE 


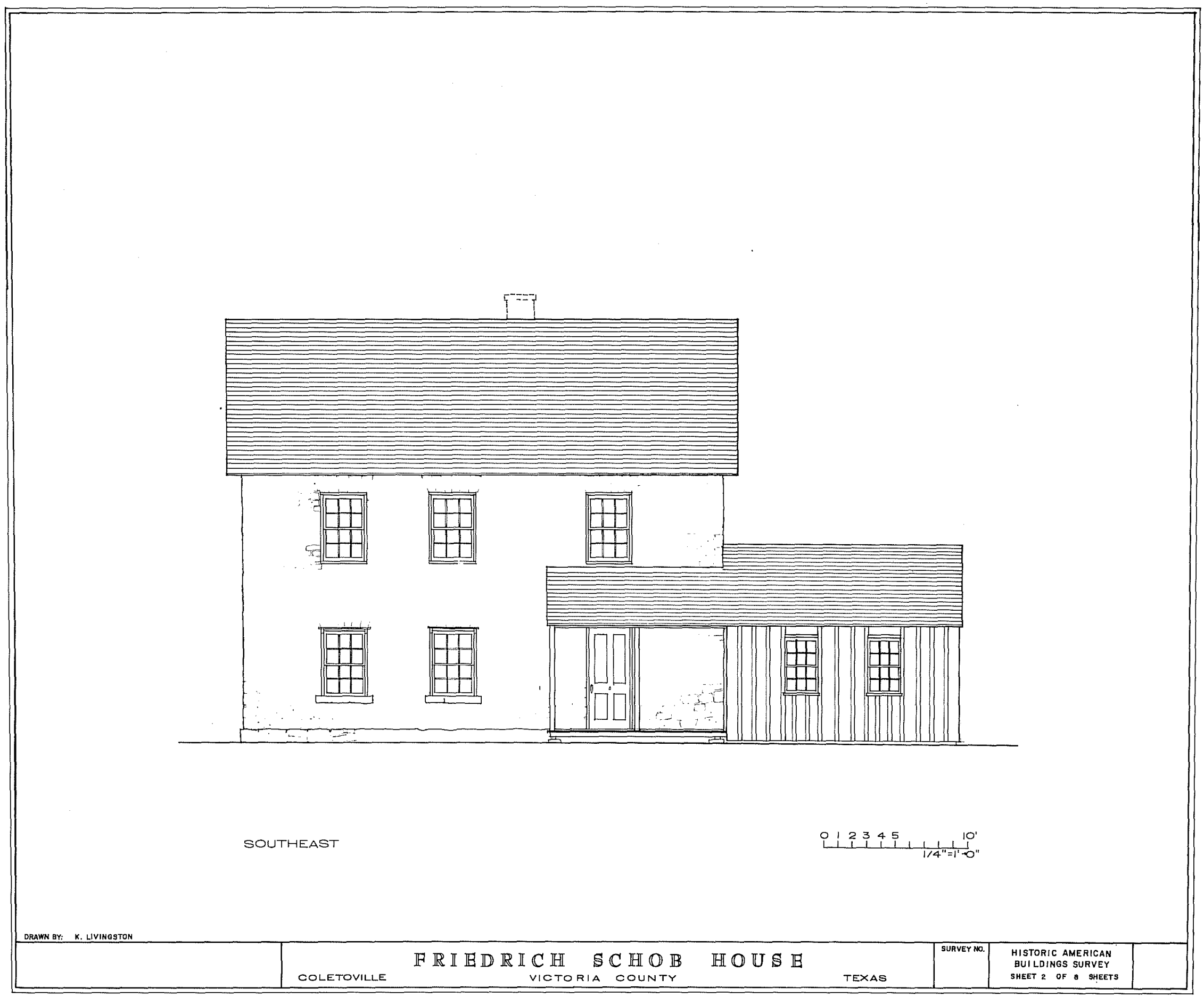




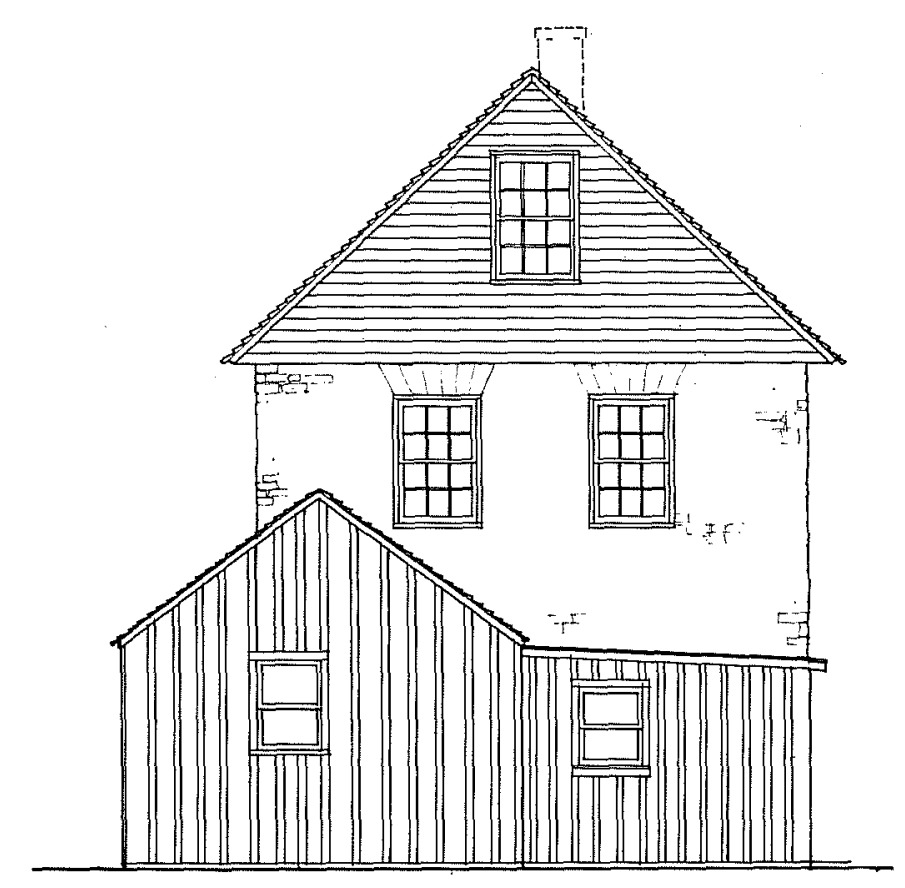

NORTHEAST

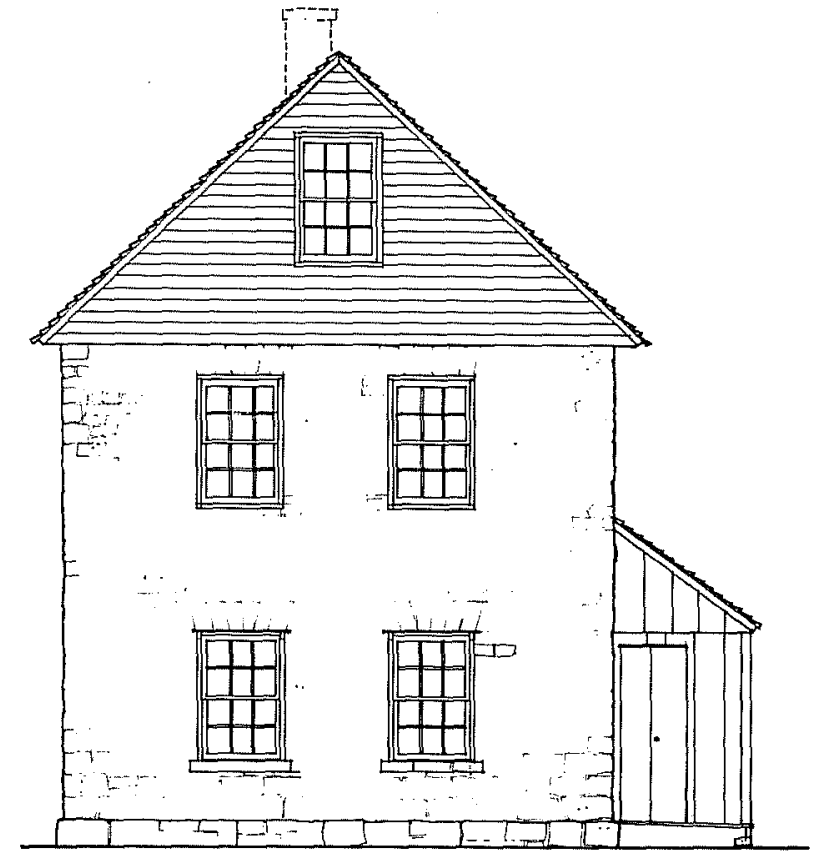

SOUTHWEST 


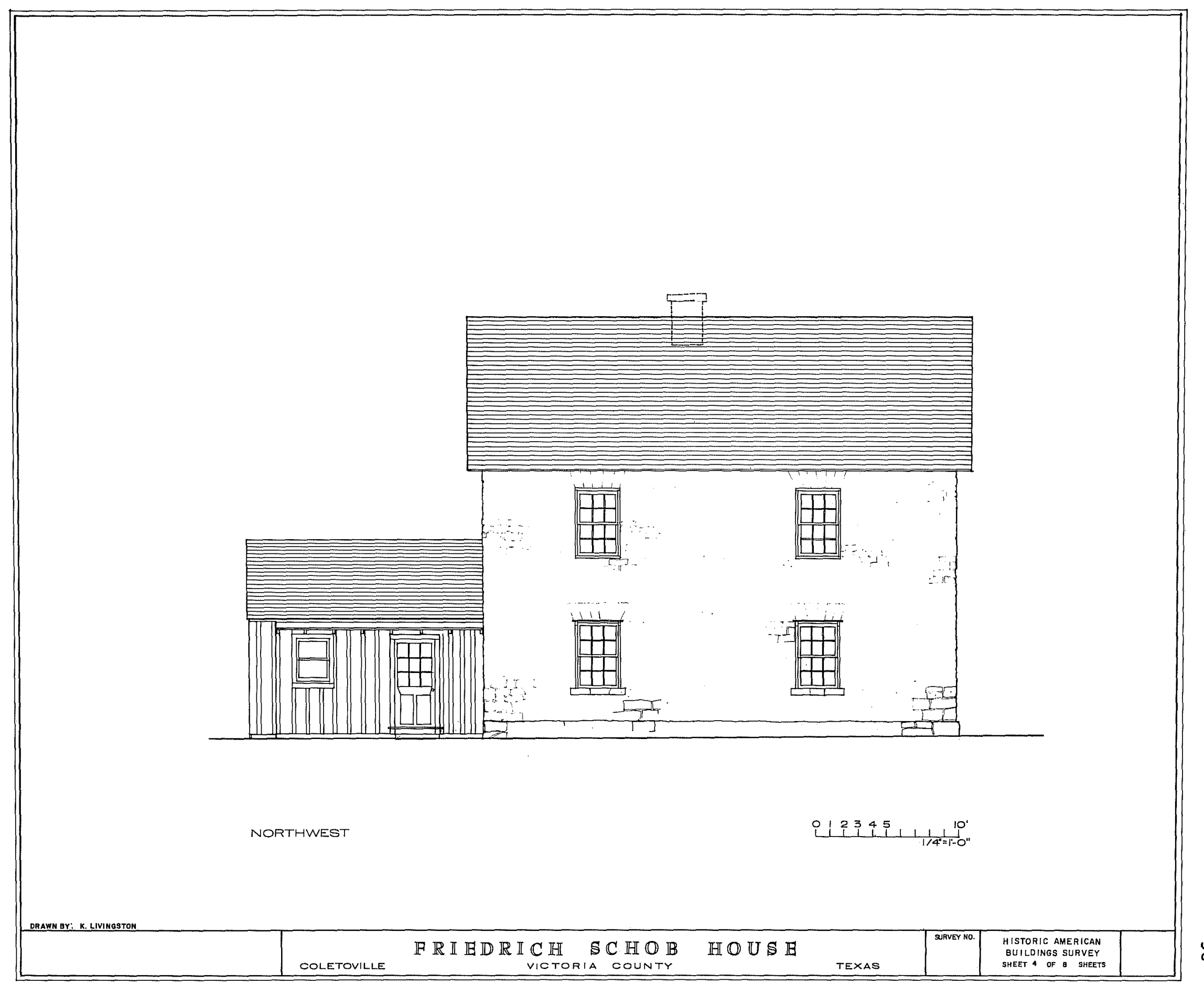




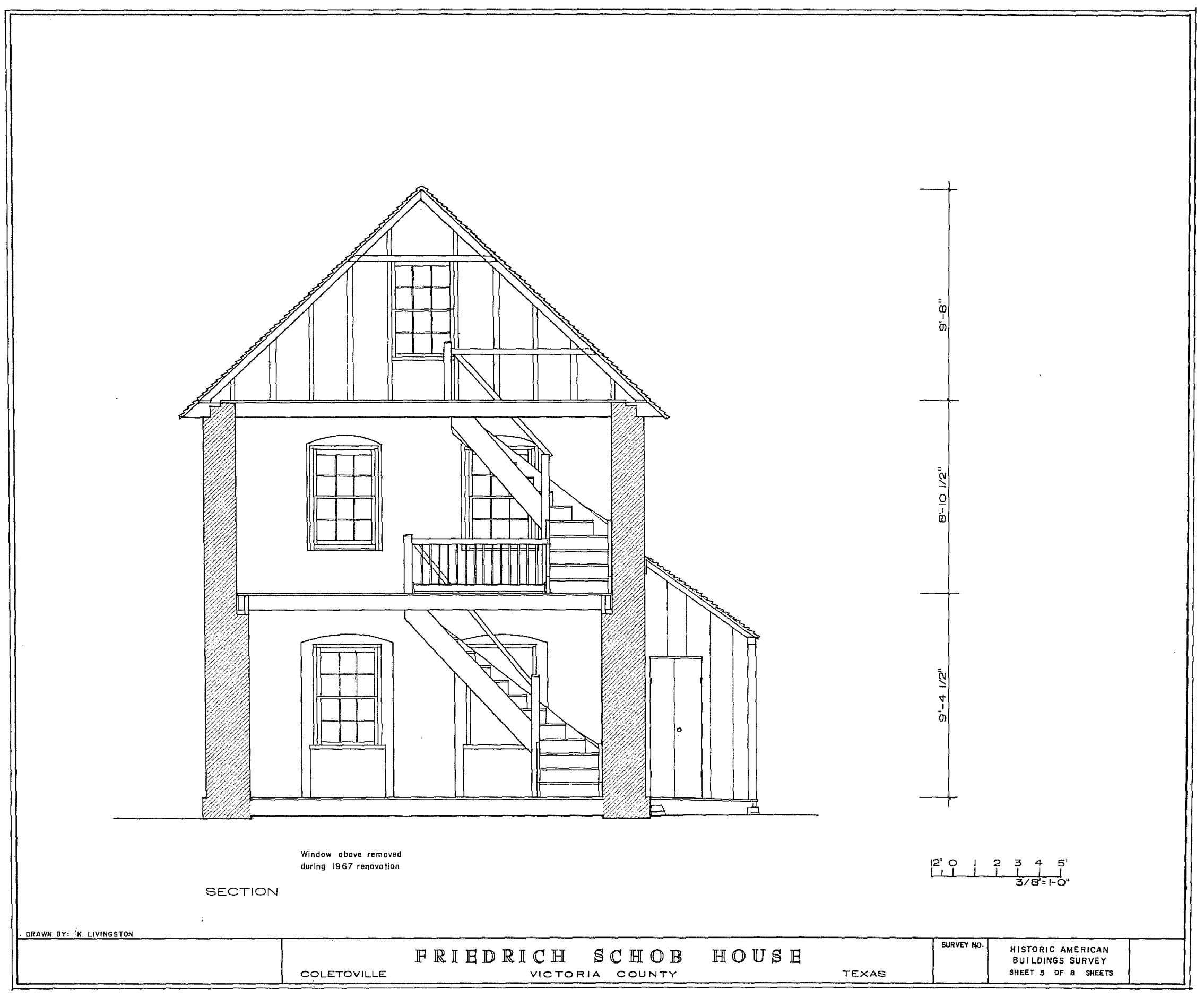




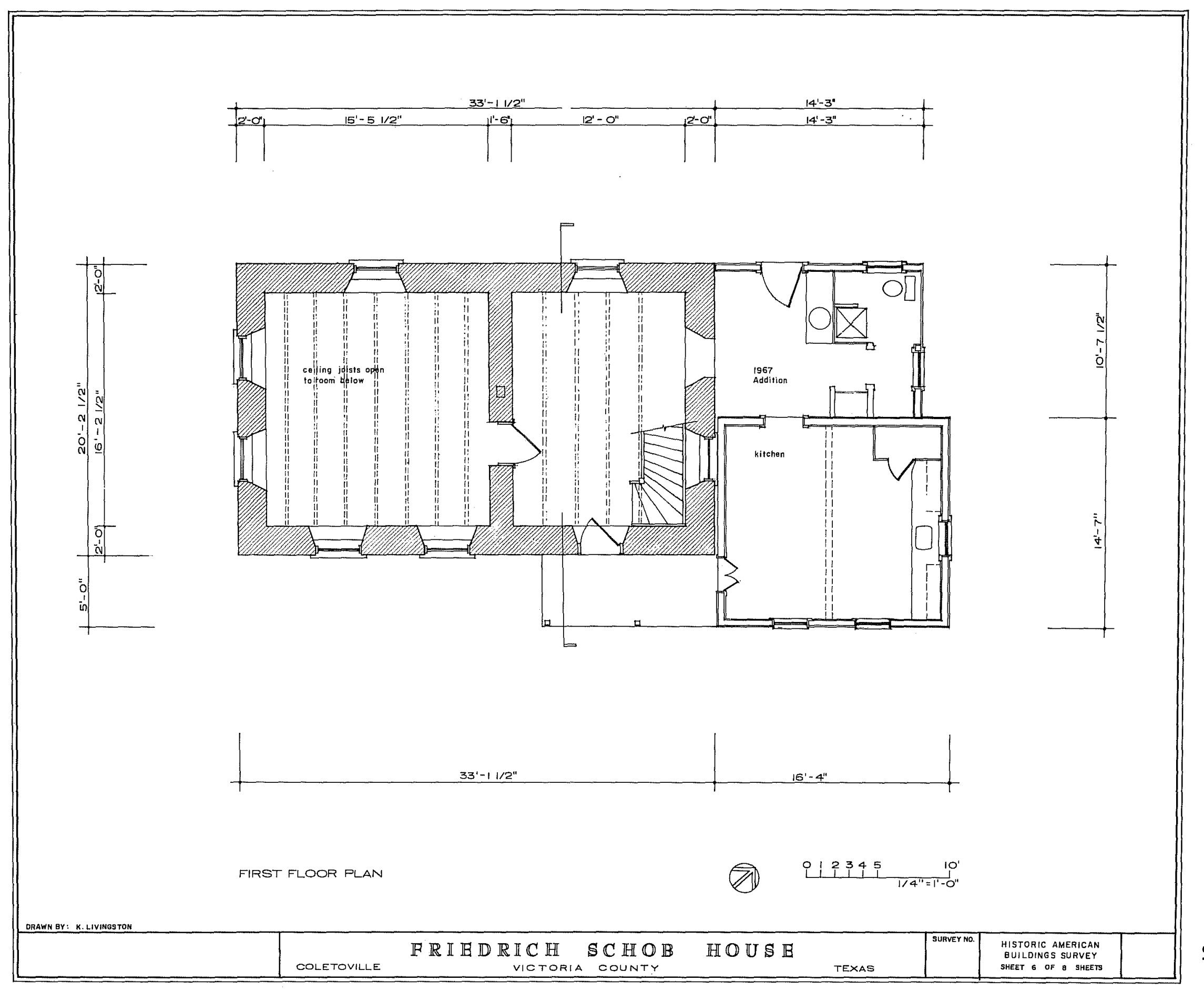




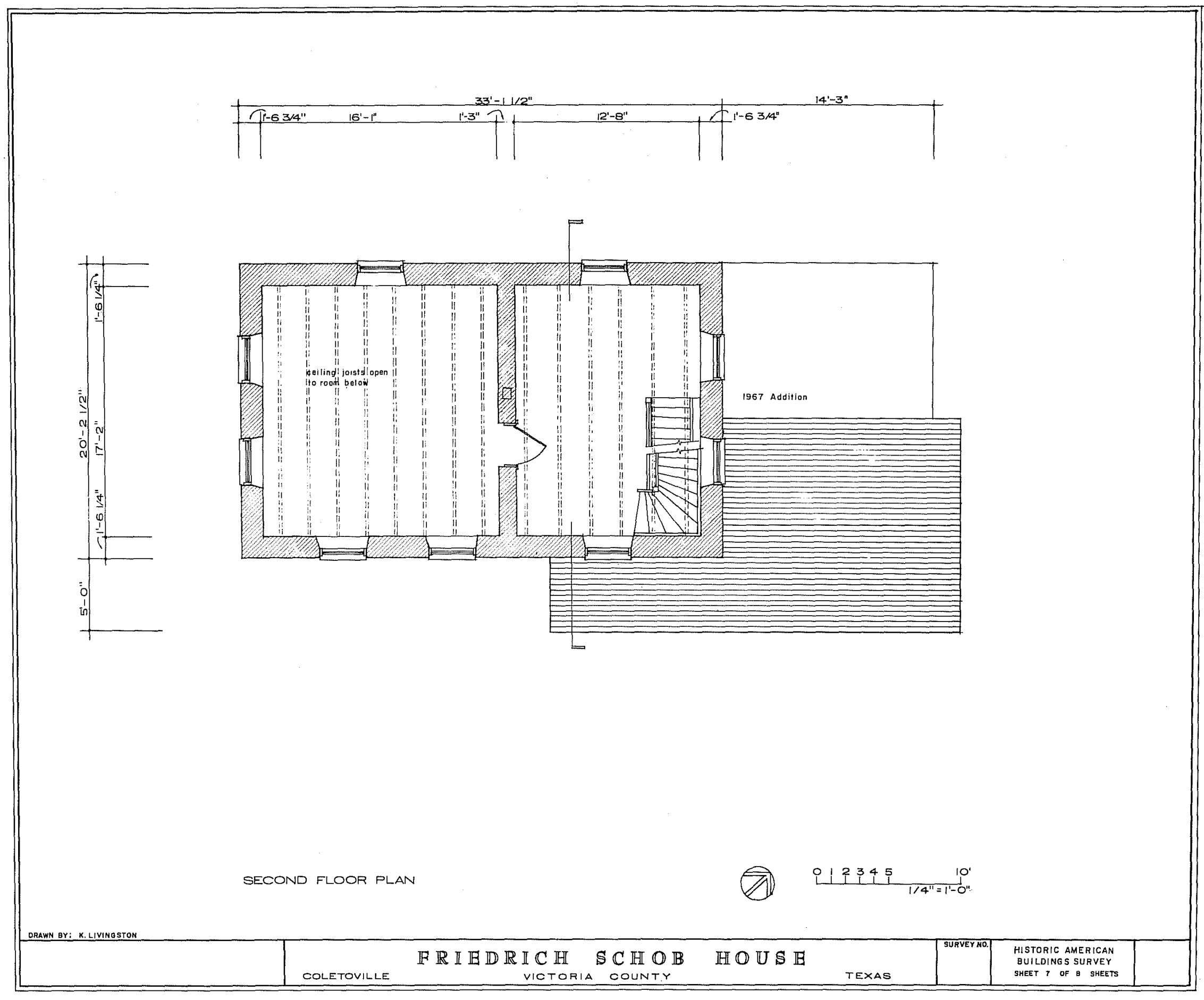




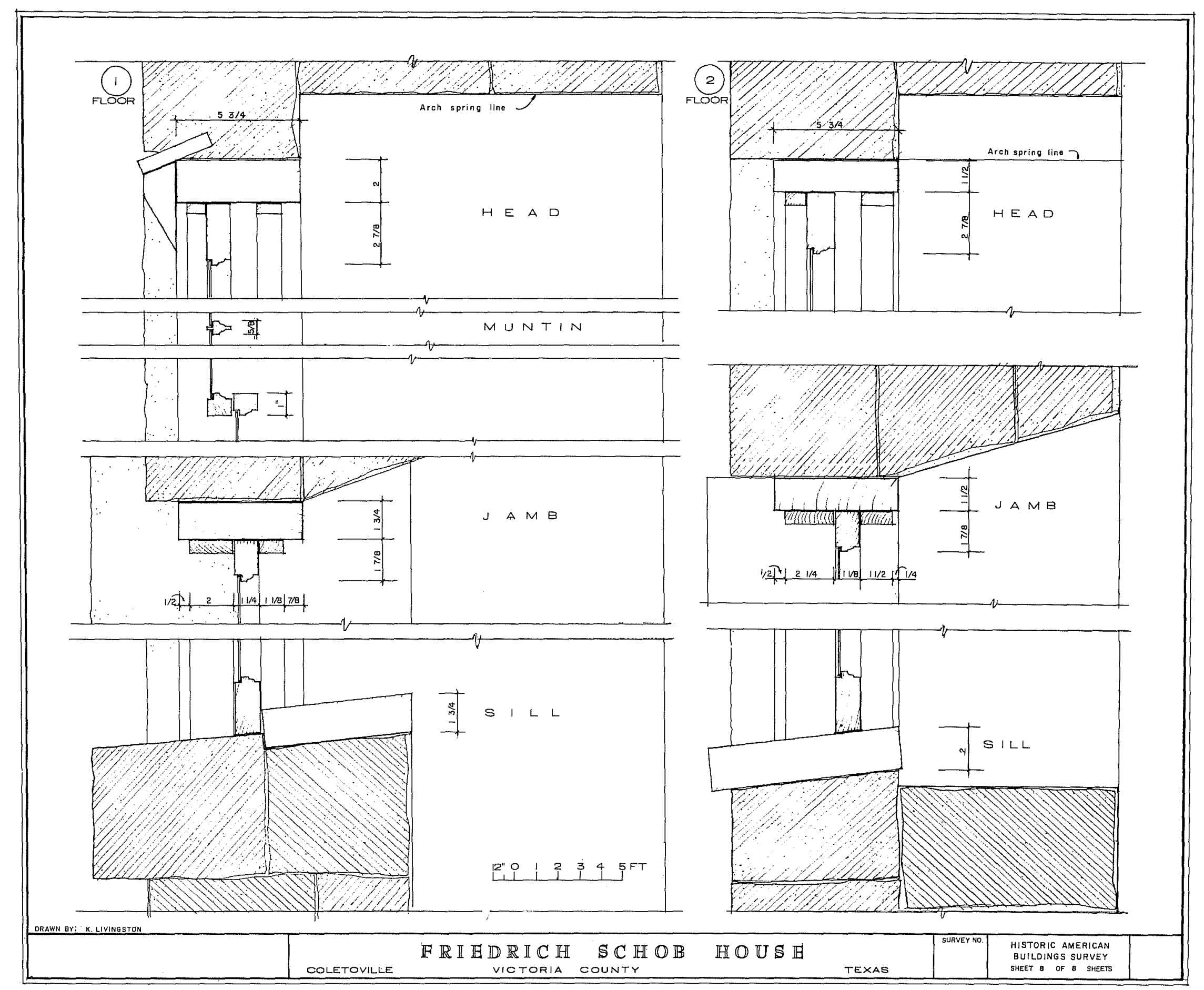

